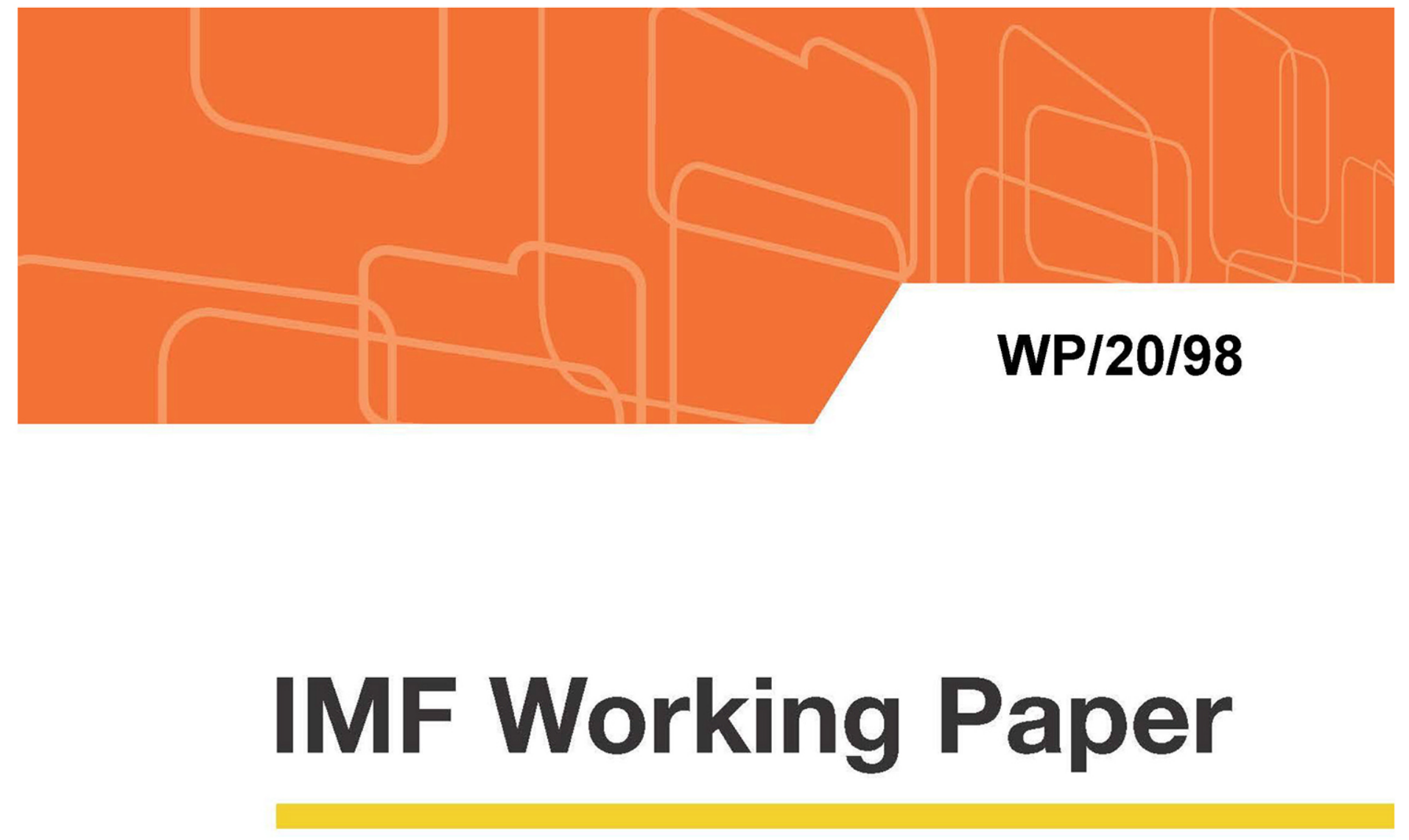

\title{
The Lack of Convergence of Latin-America Compared with CESEE: Is Low Investment to Blame?
}

by Bas B. Bakker, Manuk Ghazanchyan, Alex Ho and Vibha Nanda

IMF Working Papers describe research in progress by the author(s) and are published to elicit comments and to encourage debate. The views expressed in IMF Working Papers are those of the author(s) and do not necessarily represent the views of the IMF, its Executive Board, or IMF management.

$$
\text { I N T E R N A T I O N A L M O N E T A R Y F U N D }
$$




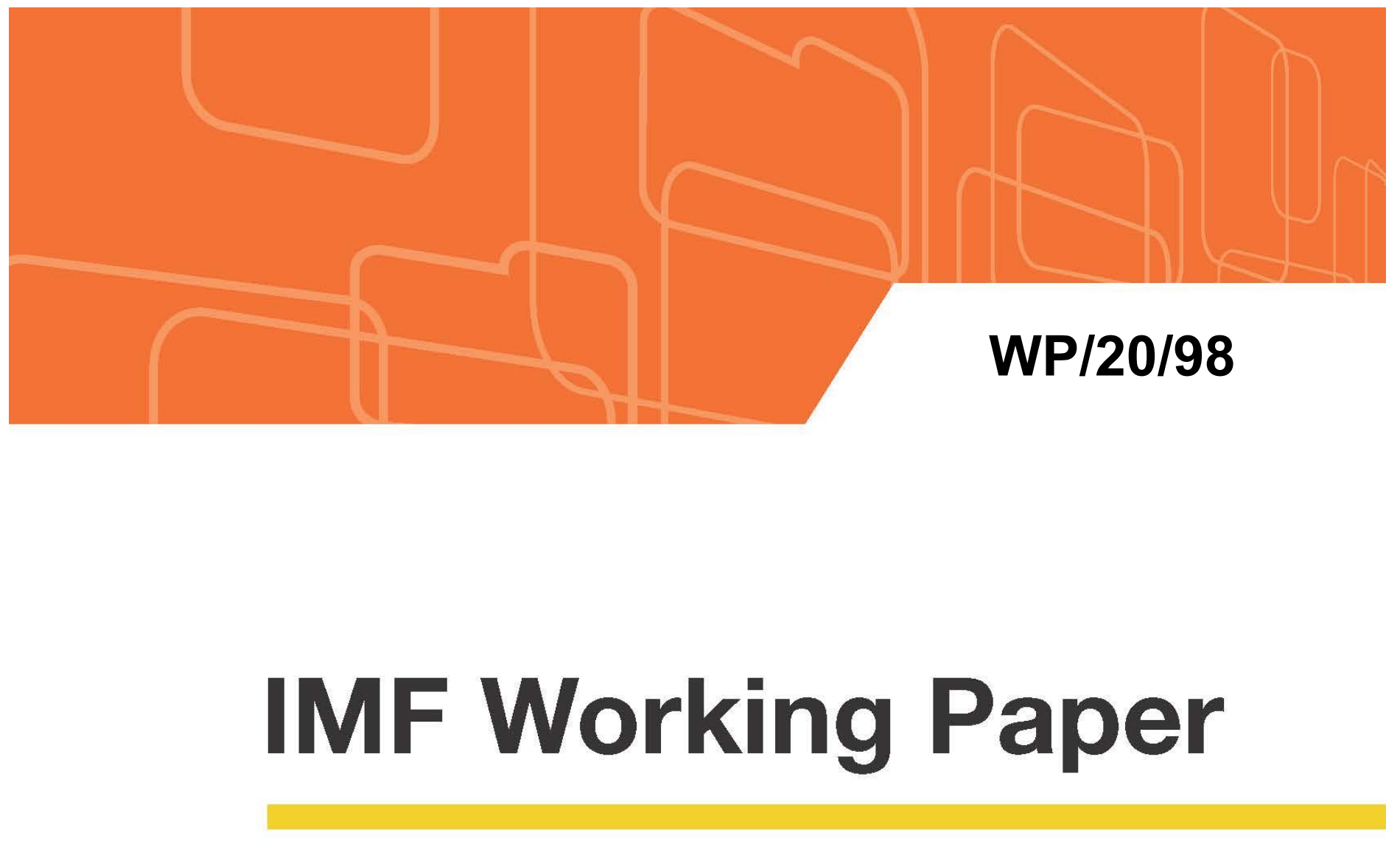

\section{The Lack of Convergence of Latin-America Compared with CESEE: Is Low Investment to Blame?}

by Bas B. Bakker, Manuk Ghazanchyan, Alex Ho and Vibha Nanda

IMF Working Papers describe research in progress by the author(s) and are published to elicit comments and to encourage debate. The views expressed in IMF Working Papers are those of the author(s) and do not necessarily represent the views of the IMF, its Executive Board, or IMF management.

$$
\text { I N T E R N A T I O N A L M O N E T A R Y F U N D }
$$




\title{
IMF Working Paper
}

Western Hemisphere Department

\section{The Lack of Convergence of Latin-America Compared with CESEE: Is Low Investment to Blame?}

\section{Prepared by Bas B. Bakker, Manuk Ghazanchyan, Alex Ho and Vibha Nanda ${ }^{1}$}

\author{
Authorized for distribution by Bas B. Bakker
}

June 2020

\section{IMF Working Papers describe research in progress by the author(s) and are published to elicit comments and to encourage debate. The views expressed in IMF Working Papers are those of the author(s) and do not necessarily represent the views of the IMF, its Executive Board, or IMF management.}

\begin{abstract}
In the last few decades there has been little convergence of income levels in Latin America with those in the United States, in sharp contrast with both emerging Asia and emerging Europe. This paper argues that lack of convergence was not the result of low investment. Latin America is poorer because of lower human capital levels and lower TFP - not because of a lower capitaloutput ratio. Cross-country differences of TFP in turn are associated with differences in human capital, governance and business climate indicators. We demonstrate that once levels of human capital and governance are taken into account, there is strong conditional cross-country convergence. Poor countries with high levels of human capital, governance or business climate indicators converge rapidly. Poor countries without those attributes do not. We show that low investment is the result of low TFP and thus GDP growth — not the cause.
\end{abstract}

JEL Classification Numbers: C53, E23, E27, E32, E62

Keywords: Economic Convergence, Growth, TFP

Author's E-Mail Address: bbakker@imf.org; MGhazanchyan@imf.org; who@imf.org; vnanda@imf.org

\footnotetext{
${ }^{1}$ This paper has benefited from discussions with Joshua Felman and Leslie Lipschitz, and from comments from Alejandro Werner, Jorge Alvarez, Carlos Barrera, Pelin Berkman, Antonio David, Jaime Guajardo, Russell Kincaid, Georgina Kachun Lok, Jorge Roldos, Piotr Trabinski, Agnieszka Urbanowska, and Marco Vega. All remaining errors are the sole responsibility of the authors.
} 


\section{Contents}

1 Introduction and Executive Summary $\quad \underline{5}$

2 Why are some countries richer than others? And why do some poorer countries converge with richer countries while others do not? $\quad \underline{9}$

2.1 Why are some countries richer than others? . . . . . . . . . . . $\underline{9}$

2.2 Convergence, TFP and Returns on Capital . . . . . . . . . . . . . 11

2.3 Central Theses . . . . . . . . . . . . . . . . . . 11

2.4 Country Samples . . . . . . . . . . . . . . . . . . . . . 12

I Growth Decomposition of Convergence: The Role of Capital Deepening, TFP and Human Capital $\quad \underline{14}$

3 A decomposition of differences in GDP levels $\quad \underline{14}$

3.1 GDP per capita and the capital-labor ratio . . . . . . . . . . . $\underline{14}$

3.2 GDP per capita and the capital-output ratio . . . . . . . . . $\underline{15}$

4 A Decomposition of GDP and GDP per Capita Growth Rates $\underline{19}$

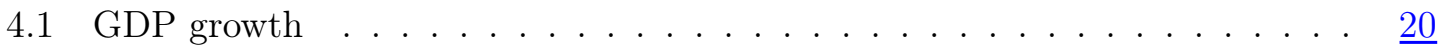

4.2 GDP per capita growth and the capital-labor ratio . . . . . . . . $\underline{20}$

4.3 GDP per capita growth and the capital-output ratio . . . . . . . $\underline{20}$

5 TFP: the link with Institutions and Human Capital $\underline{29}$

5.1 Institutions and TFP . . . . . . . . . . . . . . . $\underline{\underline{29}}$

5.2 Human Capital and TFP . . . . . . . . . . . . . . $\frac{36}{36}$

5.3 Human Capital, Institutions and TFP . . . . . . . . . . . $\underline{37}$

II What Explains Convergence? $\underline{42}$

6 Income Levels, Institutions and Human Capital $\underline{42}$

6.1 Indicators of Institutional Strength, Competitiveness, Human Capital and GDP per Capita . . . . . . . . . . . . . . . . . 42

6.2 Disentangling the importance of the various factors . . . . . . . . $\underline{46}$

7 Convergence: The Role of Changes in Fundamentals $\underline{48}$

7.1 Conditional convergence with Initial Income Levels and Fundamentals . . . $\underline{48}$

7.2 Conditional convergence with Initial Income Gap and Change in Fundamentals $\underline{51}$

III Why has Latin America not converged like CESEE? 
8 Explaining the differences in convergence between Latin America and CESEE $\underline{53}$

8.1 Why has CESEE converged rapidly? . . . . . . . . . . . . . . $\frac{57}{57}$

8.2 Why has Latin America not converged? . . . . . . . . . . . . . . $\underline{61}$

9 Is low investment in Latin America endogenous? $\underline{64}$

9.1 Why faster TFP and population growth leads to higher investment: Theory $\underline{64}$

10 Conclusion $\quad \underline{66}$

Bibliography $\quad \underline{67}$

A Countries included $\quad \underline{72}$

B Data Sources $\quad \underline{73}$ 


\section{Introduction and Executive Summary}

In the last few decades there has been little convergence of GDP per capita levels in Latin America with those in the United States. This is in sharp contrast with emerging Asia and emerging Europe, which both have seen rapid convergence (Figure 1.1).

It has often been argued that the lack of convergence of Latin America is the result of low investment. It is indeed true that, compared with emerging Asia, investment levels in Latin America have been modest (Figure 1.2). However, Emerging Europe, which has had much more modest investment levels than Emerging Asia, has also seen rapid convergence in the past 25 years, casting doubt on the hypothesis that lack of investment really is to blame. Indeed, Mexico has been growing more slowly than Poland in per capita terms, but investment levels in Mexico have been higher (Figure 1.3); and Mexico has a much higher capital-output ratio (Figure 1.4).

This paper argues that lack of convergence of Latin America is the result of low total factor productivity (TFP) growth, which is associated with less human capital and lower scores on governance and business climate indicators. ${ }^{1}$ Low investment in turn is the result of low TFP growth, which makes high investment less profitable.

We first show that cross-country differences in GDP per capita levels are the result of differences in human capital and TFP levels, not of differences in the capital-output ratio.

We then show that cross-country differences in GDP growth rates are also the result of differences in human capital and TFP growth, rather than capital deepening (an increase in the capital-output ratio).

We next show that cross-country differences of TFP are associated with cross-country differences in human capital, governance and business climate indicators. Countries with high human capital, strong governance and favorable business climates have high TFP; countries with low human capital, weak governance and poor business climates have low TFP.

If cross-country differences in income are the result of differences in human capital and TFP, and TFP depends on human capital and institutions, we would expect that crosscountry differences in income levels are the result of differences in institutions and human capital. We show that this is indeed the case.

We also demonstrate that once levels of human capital and governance are taken into account, there is strong conditional cross-country convergence. Poor countries with high levels of human capital, governance or business climate indicators converge rapidly. Poor countries without those attributes do not.

We use this analysis to explain the difference between strong convergence in Emerging Europe and lack of convergence in Latin America in the past 25 years.

\footnotetext{
${ }^{1}$ Total factor productivity (TFP) is the portion of output not explained by the amount of inputs used in production. As such, its level is determined by how efficiently and intensely the inputs are utilized in production (Comin (2008)).
} 
In the mid 1990s, after the fall of communism, incomes in Emerging Europe were lower than what could be expected given relatively high levels of human capital. As it also adapted Western European institutions (in the run-up to EU membership), TFP surged, and the region converged rapidly. In Latin America, income levels in the mid 1990s were not out of line with institutions and human capital. Moreover, governance indicators subsequently deteriorated in many countries. These factors help explain why Latin America did not see strong convergence.

It should be noted that other factors that are often mentioned to explain the disappointing growth performance of Latin America do not help explain why CESEE grew faster. For example, the poorer growth performance of Latin America was not due to higher macroeconomic volatility. Latin American countries grew less than countries in CESEE, but they had also less growth volatility (Figure 1.5). Indeed, with the notable exception of Argentina, growth volatility among the large Latin American countries was substantially less than that in CESEE. Commodity prices can also not explain why Latin America grew less. Most Latin American countries had positive terms of trade changes, while most CESEE countries had negative changes (Figure 1.6).

We show why faster growing countries have higher investment rates. If the marginal return on capital is the same across countries, then countries with faster TFP growth must see see a faster increase in the capital-labor ratio, which necessitates a higher investment rate. Similarly, countries with population growth will need higher investment rates to prevent the capital-labor ratio from falling.

Some caveats. The paper does not argue that investment does not matter. Higher investment would make Latin America richer, although the impact would be modest only. In addition, to the extent that technological progress is embodied in new capital, TFP and investment may not be fully independent: higher investment could also boost TFP. Rather the paper argues that differences in capital deepening do not explain why CESEE has converged rapidly over the past 25 years, while Latin America has not.

This paper was mostly written before the Covid-19 pandemic hit. It focuses on the pre-covid years only. At this stage it is too early too tell whether the pandemic will affect convergence, and whether human capital, governance and the business climate matter for the rebound from Covid-19. We leave this important topic for future research. 
Figure 1.1. GDP per Capita

(Percent of US GDP Per Capita)
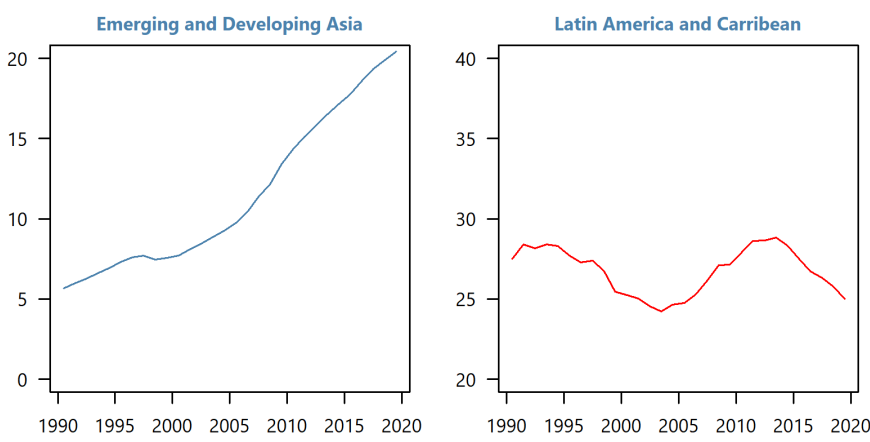

Figure 1.2. Investment (Percent of GDP)

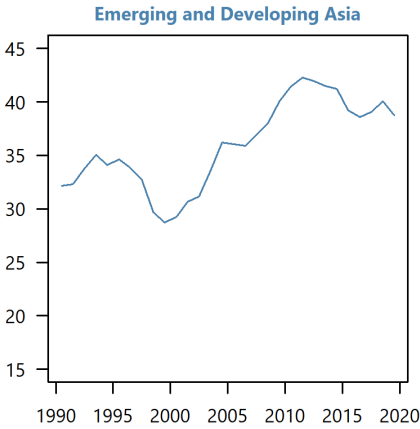

Source: WEO Database

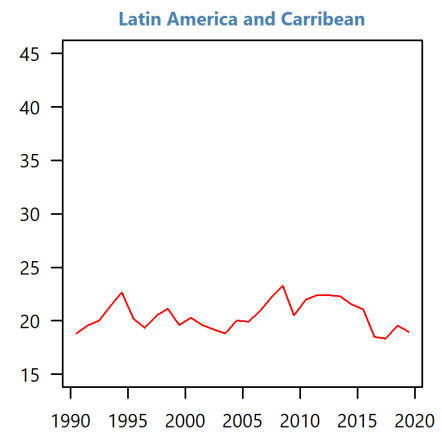

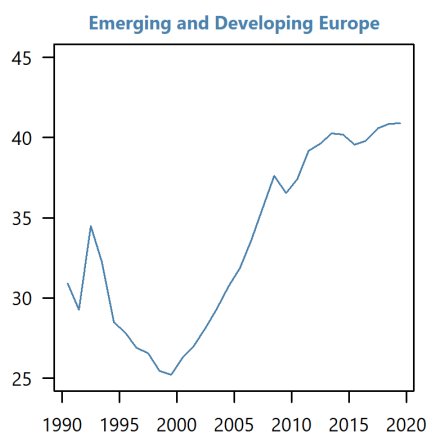

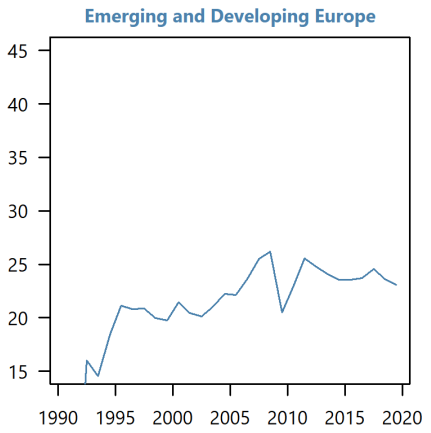

Figure 1.3. Mexico and Poland
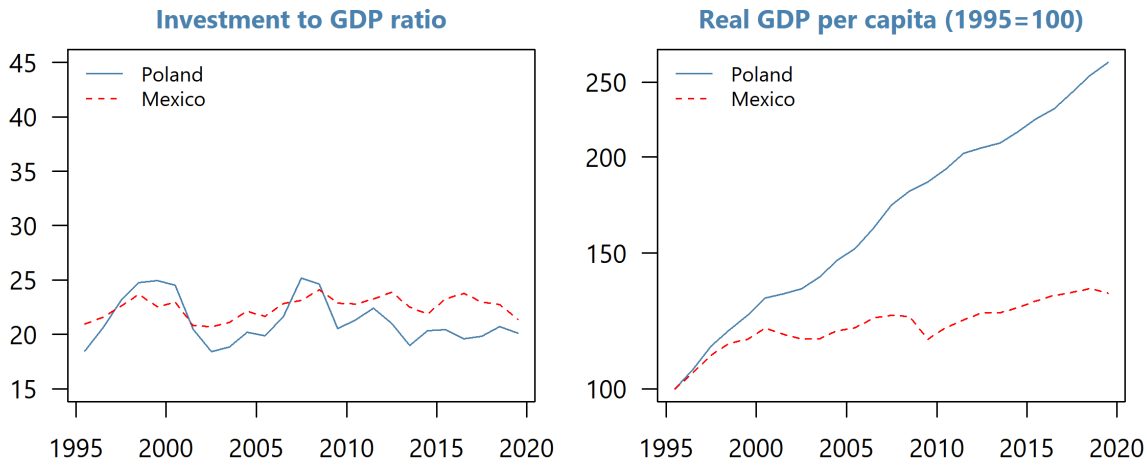

Source: WEO Database 


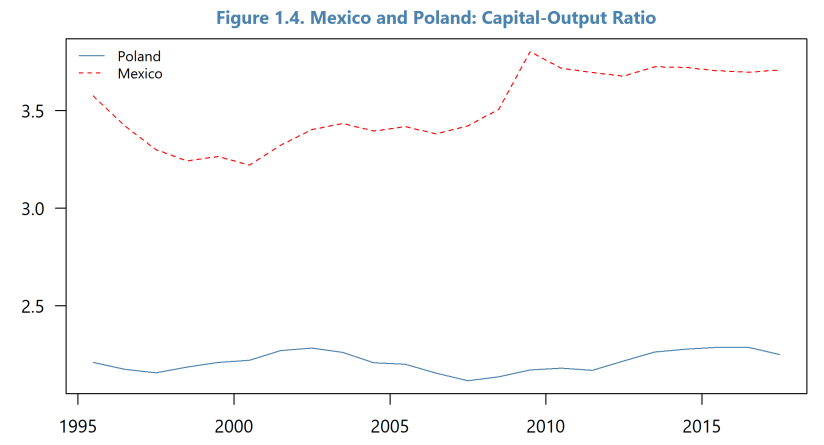

Source: Penn world tables, version 9.1

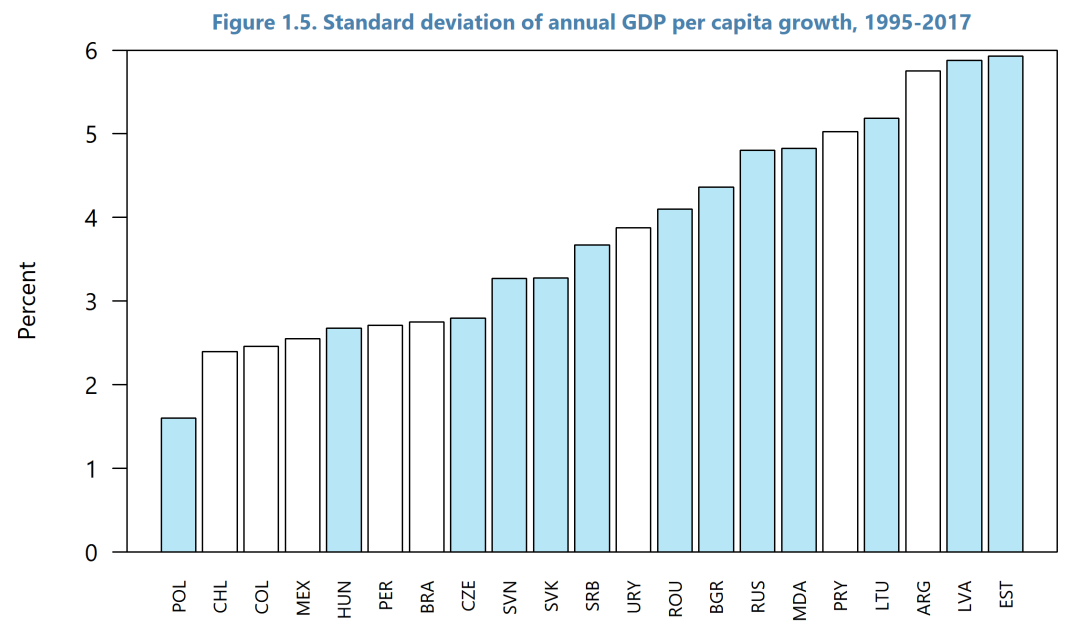

Source: Penn World Tables 9.1

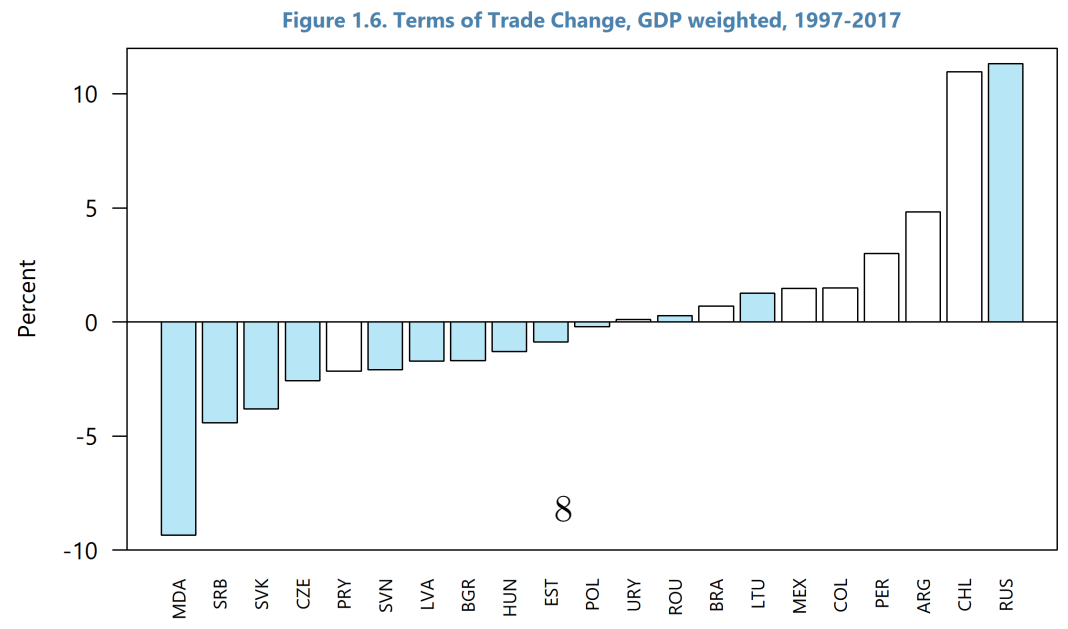

Source: IMF Primary Commodity Prices Database

CInternational Monetary Fund. Not for Redistribution 


\section{Why are some countries richer than others? And why do some pooren countries converge with richer countries while others do not?}

\subsection{Why are some countries richer than others?}

Mathematically, countries can have a higher GDP per capita because they have a higher employment-to-population ratio $\left(\frac{L}{P}\right)$ or because they have higher labor productivity $\left(\frac{Y}{L}\right)$ :

$$
\frac{Y}{P}=\frac{L}{P} \frac{Y}{L}
$$

In practice, cross-country income differences are due to labor productivity but not employmentto-population ratio (Figure 2.1).

What, then, explains differences in labor productivity? Assuming a Cobb-Douglas production function with constant returns to scale, labor productivity is equal to:

$$
\frac{Y}{L}=A\left(\frac{K}{L}\right)^{\alpha}
$$

Labor productivity can increase because TFP increases or because the capital-labor ratio increases.

Note that increases in the capital-labor ratio are not independent of what happens with TFP. Higher TFP will lead to a higher capital-labor ratio. To see this, suppose a country starts on point $A$ in Figure 2.2 (borrowed from Hulten and Isaksson (2007)).

- If the capital-labor ratio rises from $k^{*}$ to $k^{* *}$, the country will move to point $B$.

- If TFP rises and the capital-labor ratio remains constant, the country will move to point $C$.

However, if TFP rises, it is unlikely that the capital-labor ratio will remain constant. In point $C$ the capital-output ratio is lower - and the return on capital higher - than in point $A .^{2}$ Assuming that the cost of capital remains unchanged, the increase in TFP will induce an increase in the capital-labor ratio to $k^{* * *}$. In point $D$, the capital-output ratio is the same as in point $A$.

In other words, the capital-labor ratio is not an exogenous variable, but one that depends on TFP. We therefore further rewrite equation (2) as: ${ }^{3}$

$$
\frac{Y}{L}=A^{\frac{1}{1-\alpha}}\left(\frac{K}{Y}\right)^{\frac{\alpha}{1-\alpha}}=A^{\frac{1}{1-\alpha}}\left(\frac{\alpha}{r}\right)^{\frac{\alpha}{1-\alpha}}
$$

It follows that countries can be poorer because they have a lower capital-output ratio (and thus a higher return on capital), or because they have lower TFP. ${ }^{4}$

\footnotetext{
${ }^{2}$ Note that the capital-output ratio in point $A$ is equal to the ratio of the capital-labor and the output-
} 
Figure 2.1. GDP per Capita Differences: Labor Productivity and Employment Rates
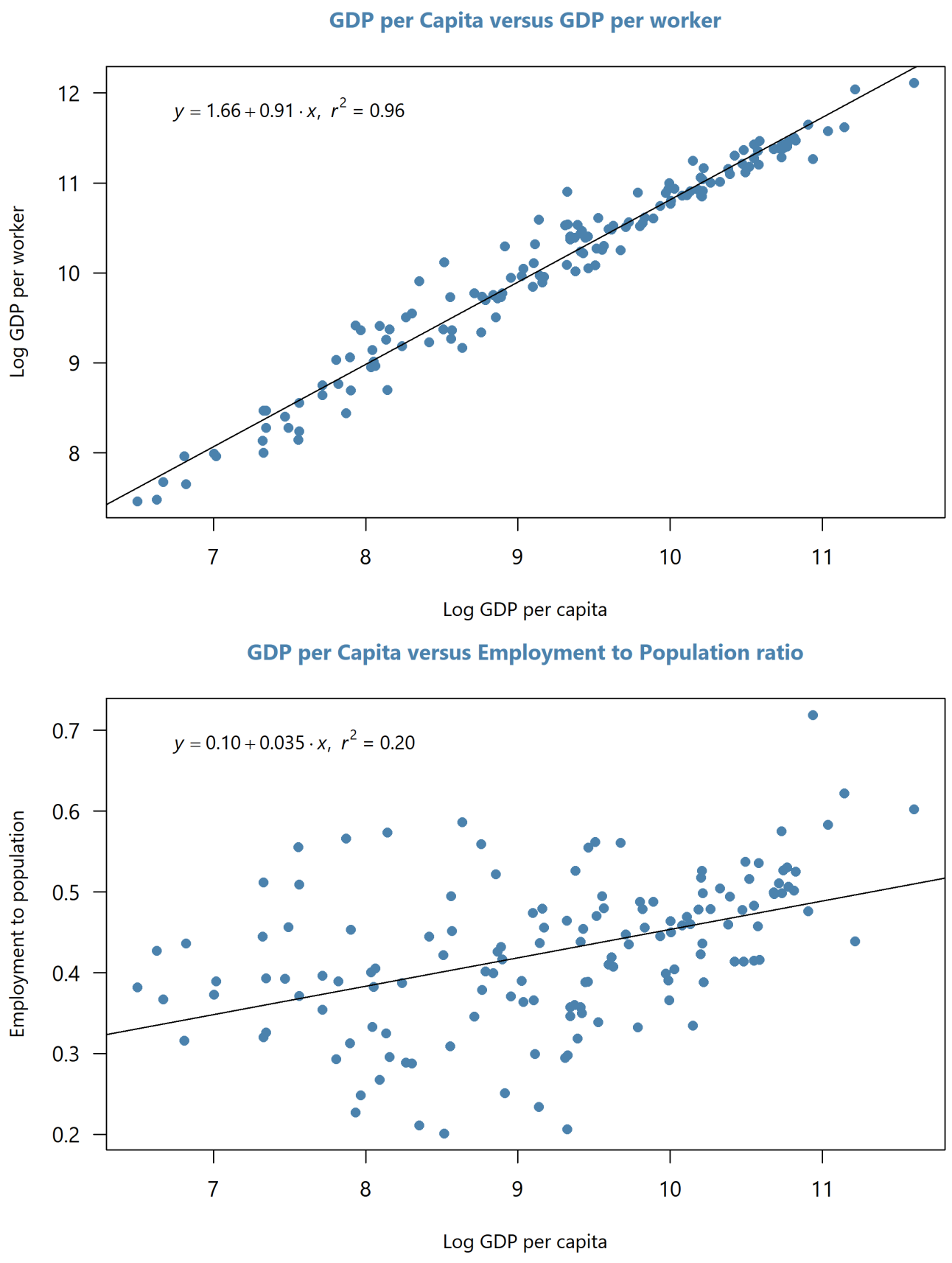

Source: Penn World Tables version 9.1

Includes all countries except OPEC and other major oil exporters. 


\subsection{Convergence, TFP and Returns on Capital}

How convergence happens, depends on whether income differences are the result of differences in the capital-output ratio, or differences in TFP:

- If all income differences are the result of differences in the capital-output ratios; and there are no differences in TFP, we would expect incomes to converge over time. Capital will flow from rich countries (where the return on capital is low) to poor countries (where the return on capital is high), and poor countries will grow faster than rich countries.

- If all income differences are the result of differences in TFP, rather than differences in the capital-output ratio, we would not necessarily expect convergence. It will depend on whether TFP converges. If it does, we would see convergence, but if it doesn't, we would not.

- If income differences are the result of both differences in TFP and differences in the capital-output ratio we would expect see conditional convergence. Countries will convergence to the income level consistent with their TFP level. As an example, consider again Figure 2.2. Assume that all countries in South America are on the black line (associated with low TFP), and all advanced countries on the red line (associated with high TFP). Then over time, and assuming that the return on capital converges, we would expect all countries in South America to end up on point $A$ and all advanced countries on point $D .^{5}$

\subsection{Central Theses}

This brings us to the central theses of this paper:

- Cross-country differences in income levels are largely the result of differences in TFP rather than differences in capital-output ratios. Poorer countries tend to have lower capital-labor ratios but not lower capital-output ratios.

- TFP differences are the result of differences in institutions. Countries with higher scores on governance indicators or business climate measures tend to have higher TFP levels.

labor ratio - the slope of the grey line.

${ }^{3}$ Note that profit maximizing implies that $\frac{K}{Y}=\frac{\alpha}{r}$.

${ }^{4}$ Countries can also be poorer because they have a lower lower $\alpha$ (i.e., capital-income share). In practice, there is no link between GDP per capita and the capital-income share (Figure 2.3), and this link will not be pursued in this paper.

${ }^{5}$ Note that the return on capital in point $A$ and $D$ is the same. 
- Human capital matters as well, both directly and indirectly. Higher human capital is associated with higher GDP per capita levels. This is in part the result of the impact of human capital on TFP levels.

- There is no unconditional convergence. There is convergence within some regions. This may occur because institutions and therefore TFP converge, rather than because capital-output ratios converge.

- Cross-country differences in GDP per capita growth rates are largely the result of differences in TFP and human capital growth - not the result of differences in capital deepening.

- CESEE converged with Western Europe because human capital levels in CESEE were similar to those in Western Europe. Convergence was further helped by an improvement in institutions in CESEE. Latin America did not converge with the United States because human capital levels were much lower, institutions in Latin America did not improve.

- High investment is endogenous. Countries that have higher TFP growth will see a faster increase in the capital-labor ratios.

\subsection{Country Samples}

In this paper, we focus on a comparison of countries in South America and Mexico with Central, Eastern and Southeastern Europe, emerging East and Southeast Asia, and advanced countries. We exclude OPEC countries and other major oil exporters, small countries and city states. We also drop countries for which some of the data used in the paper are not available. This leaves us with a group of 47 countries (Annex A). 
Figure 2.2. Output per worker, TFP and Capital-Deepening

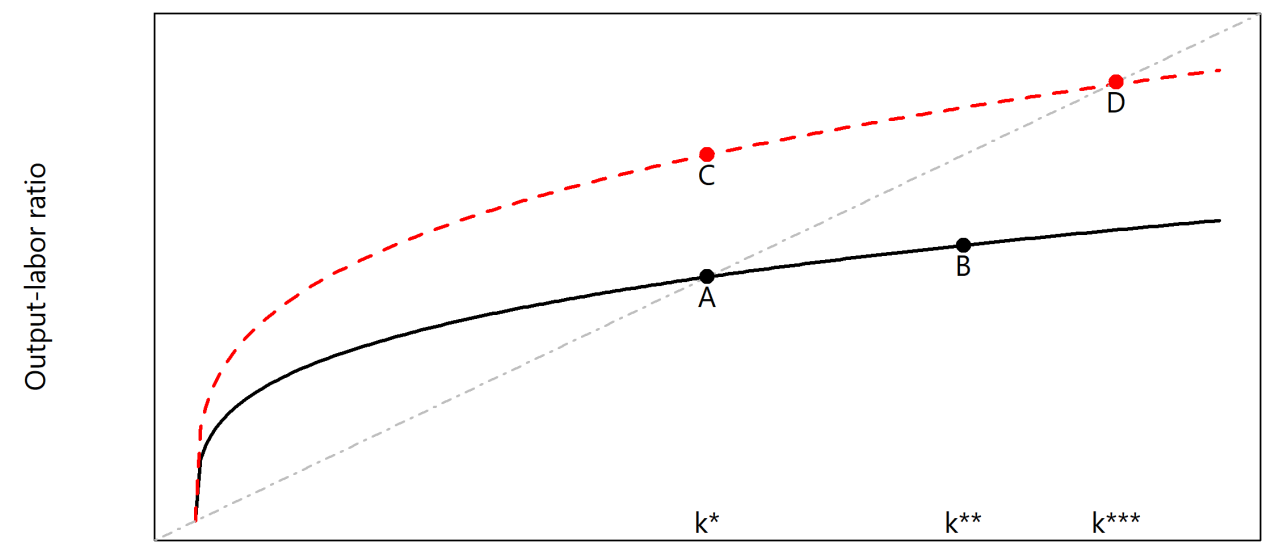

Capital-labor ratio

Source: IMF staff calculations.

Figure 2.3. Per Capita GDP and Capital Income Share

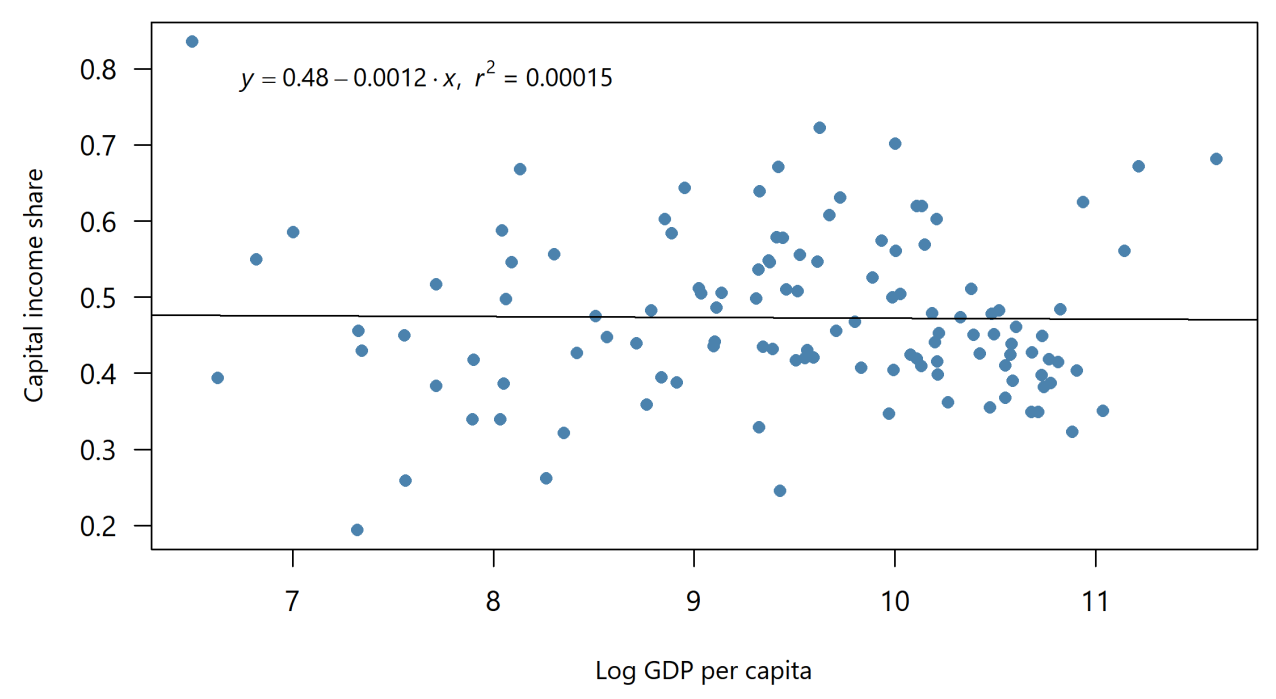

Source: Penn world Tables 9.1

Includes all countries except OPEC and other major oil producers.

13

CInternational Monetary Fund. Not for Redistribution 


\section{Part I \\ Growth Decomposition of Convergence: The Role of Capital Deepening, TFP and Human Capital}

\section{A decomposition of differences in GDP levels}

Consider the following Cobb-Douglas production function with constant returns to scale.

$$
Y=A K^{\alpha}(H L)^{1-\alpha}
$$

where $A$ is TFP, $H$ is human capital, $L$ is employment (in hours) and $K$ is the capital stock.

\subsection{GDP per capita and the capital-labor ratio}

Divide both sides of equation (4) by $L$ :

$$
\frac{Y}{L}=A\left(\frac{K}{L}\right)^{\alpha}(H)^{1-\alpha}
$$

Taking logs:

$$
\log \left(\frac{Y}{L}\right)=\alpha \log \left(\frac{K}{L}\right)+(1-\alpha) \log (H)+\log (A)
$$

Using $\log \left(\frac{Y}{L}\right)=\log \left(\frac{Y}{P}\right)-\log \left(\frac{L}{P}\right)$, where $P$ is population, we can rewrite this as:

$$
\log \left(\frac{Y}{P}\right)=\log \left(\frac{L}{P}\right)+\alpha \log \left(\frac{K}{L}\right)+\log (A)+(1-\alpha) \log (H)
$$

Lower GDP per capita than the US can be the result of a lower employment-topopulation ratio, a lower capital-labor ratio, lower TFP and lower human capital.

Figure 3.1 decomposes differences in GDP per capita levels along the lines of equation (7). ${ }^{6}$ Poorer countries are poorer both because they have a lower capital-labor ratio, and because human capital and TFP is lower.

\footnotetext{
${ }^{6}$ As $\alpha$ differs accross countries, if we compare country $i$ with the United States we take for $\alpha$ the average of the capital income share of country $i$ and the capital income share of the United States. See Inklaar et al. (2019).
} 


\subsection{GDP per capita and the capital-output ratio}

However, equation (7) underestimates the contribution of TFP increases to growth. An increase in the capital-labor ratio may not be an exogenous contributor to growth, but rather the result of the increase in TFP (Hall and Jones, 1999, Klenow and RodríguezClare, 1997). Suppose, for example, that the level of $A$ rises with no change in the saving rate. The resulting higher output increases the amount of physical capital (since the premise of the example is that the saving rate is unchanged). ${ }^{7}$

We therefore prefer a slightly different decomposition. In line with the decomposition considered in Hall and Jones (1999), we subtract $\alpha \log \left(\frac{Y}{L}\right)$ on both sides of equation (7)

$$
\log \left(\frac{Y}{P}\right)-\alpha \log \left(\frac{Y}{L}\right)=\log \left(\frac{L}{P}\right)+\alpha \log \left(\frac{K}{Y}\right)+(1-\alpha) \log (H)+\log (A)
$$

This can be rewritten as

$$
\log \left(\frac{Y}{P}\right)-\alpha \log \left(\frac{Y}{P}\right)=(1-\alpha) \log \left(\frac{L}{P}\right)+\alpha \log \left(\frac{K}{Y}\right)+(1-\alpha) \log (H)+\log (A)
$$

It follows that:

$$
\log \left(\frac{Y}{P}\right)=\log \left(\frac{L}{P}\right)+\frac{\alpha}{1-\alpha} \log \left(\frac{K}{Y}\right)+\frac{\log (A)}{1-\alpha}+\log (H)
$$

Figure 3.2 shows the revised decomposition of differentials in GDP per capita levels. The chart shows that differences between other countries and the US are mainly due to human capital and TFP. They are not due to a lower capital-output ratio.

This impression is confirmed by Figure 3.3, which shows the contribution of human capital and TFP (top panel) and capital deepening (bottom panel) to differences in GDP

per capita with the US. These charts show that income differences are due to human capital and TFP — not capital deepening.

\footnotetext{
${ }^{7}$ The example is from page 156 in Romer (2019).
} 
Figure 3.1. Decomposition of deviation of GDP per capita from US, 2017

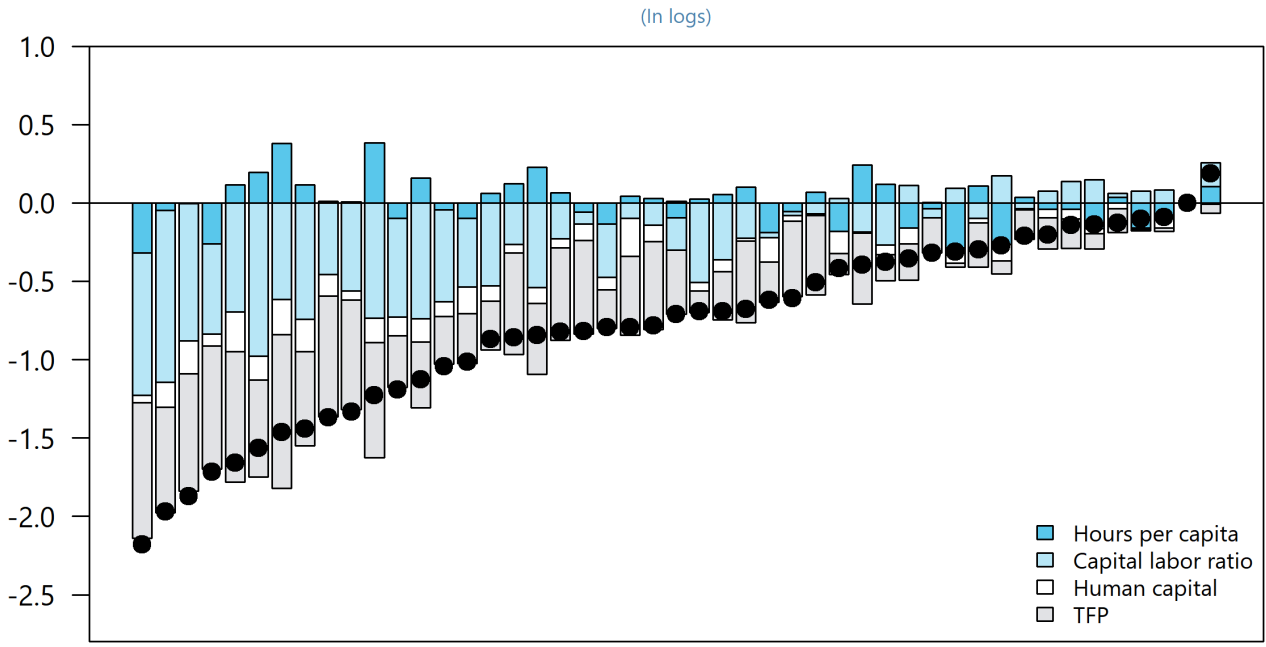

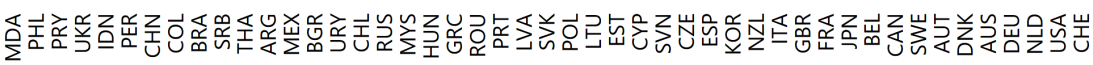

Source: Penn World Tables 9.1

Figure 3.2. Decomposition of deviation of GDP per capita from US, 2017 $(\ln \log s)$

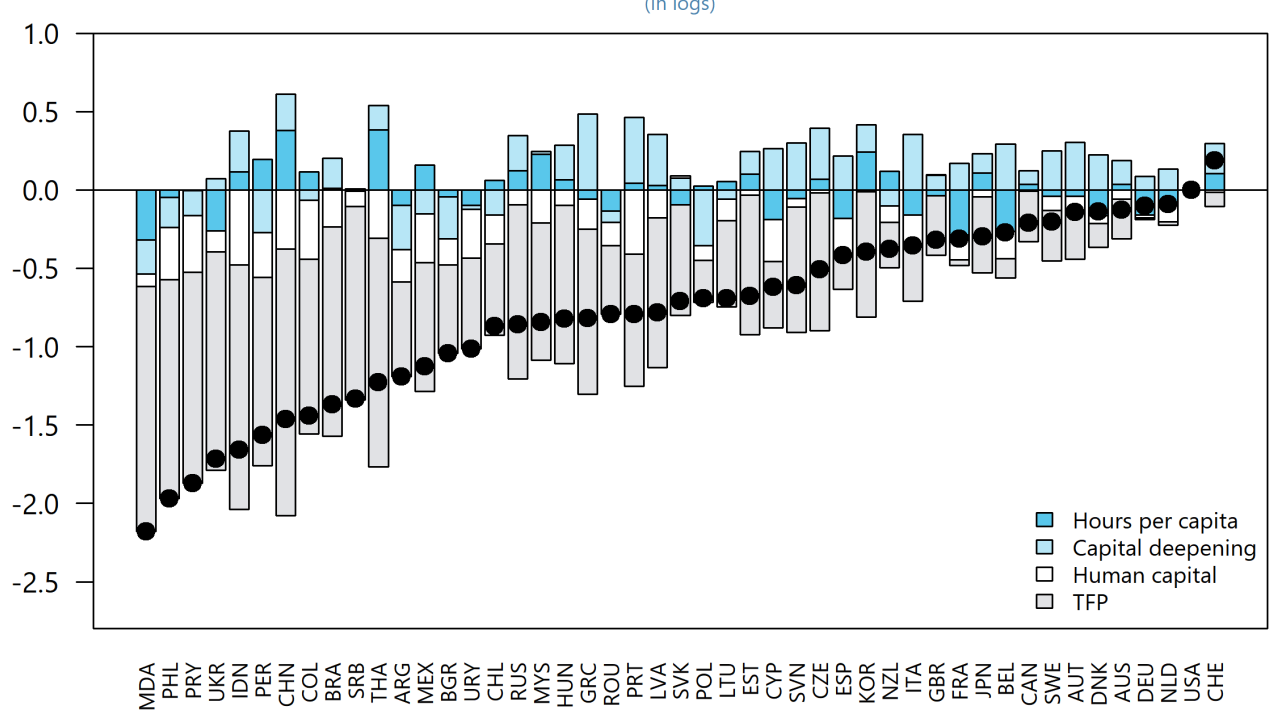


Figure 3.3. Deviation in GDP per Hour from US: The Role of Technical Progress and Human Capital versus Capital Deepening

The role of human capital and labor augmenting progress

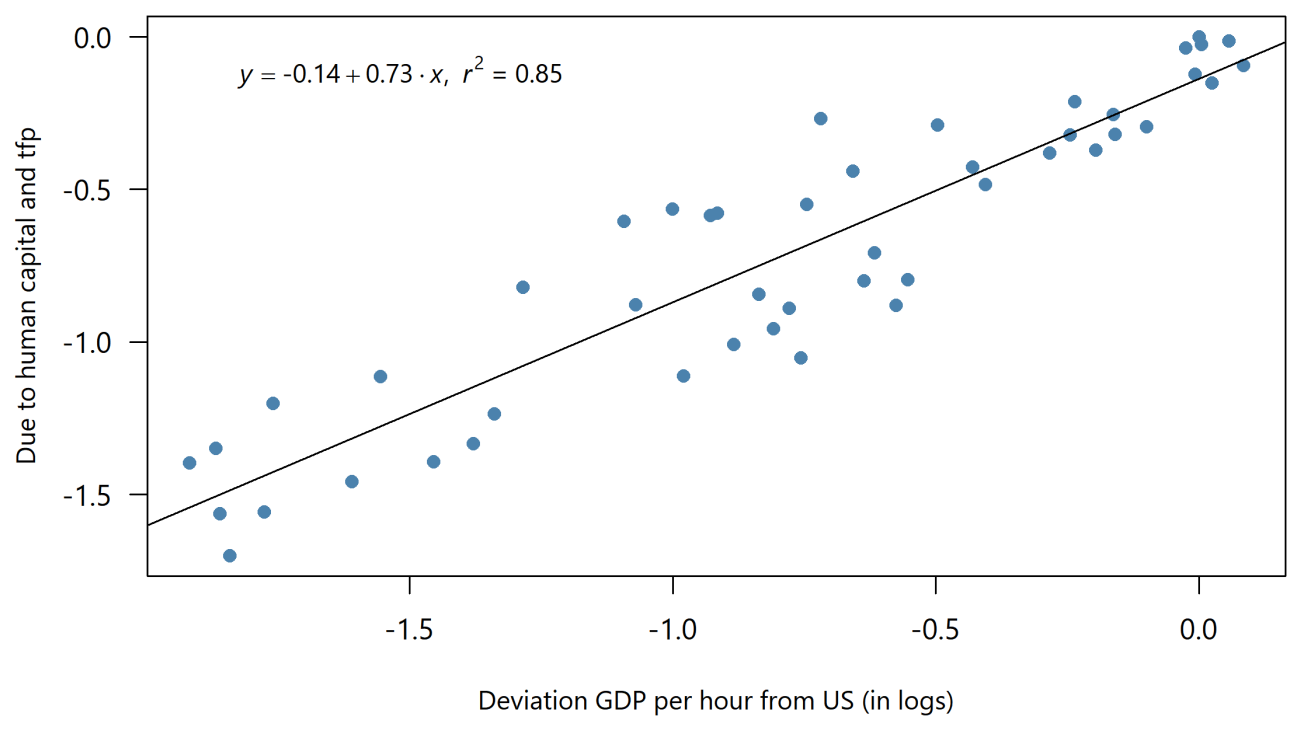

The role of capital deepening

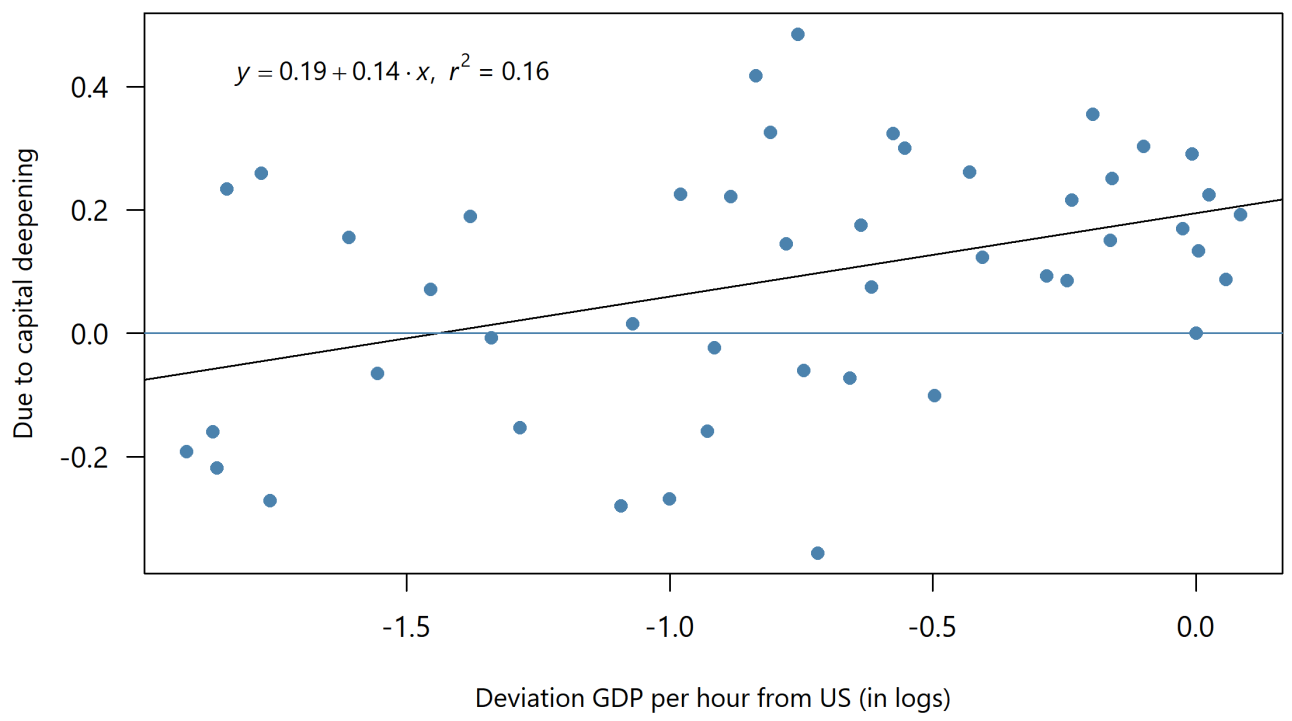

Source: Penn World Tables 9.1. 


\section{Higher investment and GDP per capital levels}

To what extent would higher investment in poorer countries reduce income differences? From equation (10) we can derive that if the capital-income ratio rises, so will GDP per capita.

$$
\Delta \log \left(\frac{Y}{P}\right)=\left(\frac{\alpha}{1-\alpha}\right) \Delta \log \left(\frac{K}{Y}\right)
$$

By how much does the steady capital-output ratio increase if investment rises? It is well known that in the steady state of a Solow-Swan model (when the investment rate $i$, working age population growth $n$, labor labor augmenting technological progress $g$ and depreciation $\delta$ are all constant), the capital-output ratio is equal to

$$
\frac{K}{Y}=\frac{i}{n+g+d}
$$

Combining both equations we get:

$$
\Delta \log \left(\frac{Y}{P}\right)=\left(\frac{\alpha}{1-\alpha}\right) \Delta \log \left(\frac{i}{n+g+d}\right)=\left(\frac{\alpha}{1-\alpha}\right) \Delta \log (i)
$$

since $n+g+\delta$ do not change.

Brazil's GDP per capita is 26 percent of that of the United States, while its investment rate is 16 percent of GDP. If its investment rate increased to 21 percent of of GDP, GDP

per capita would rise to 31 percent of the US level. ${ }^{8}$ In other words, higher investment in poorer countries would help reduce the gap with rich countries, but the contribution would be modest.

\footnotetext{
${ }^{8}$ Using a capital income share $\alpha$ of 0.45 (the average over the $1995-2017$ period).
} 


\section{A Decomposition of GDP and GDP per Capita Growth Rates}

We next look at what explains changes in GDP and per capita GDP, TFP growth or capital deepening?

Disagreements in the growth accounting literature on whether growth differences are due to differences in "capital deepening" or differences in TFP growth are in large part semantic, as they use different definitions of capital deepening. Is capital deepening an increase in the capital stock, an increase in the capital-labor ratio, or an increase in the capital-output ratio? Different definitions give very different results.

An example. Suppose GDP grows by 4 percent. Employment grows by 2 percent, the capital stock by 4 percent, and TFP by 1 percent. The labor income share is 50 percent.

- If we look at the growth of GDP, 75 percent is due to factor accumulation and 25 percent due to TFP. ${ }^{9}$

- If we look at the growth of GDP per worker, 50 percent is due to an increase in the capital-labor ratio and 50 percent due to TFP. ${ }^{10}$

- If we look at the growth of GDP per worker, 0 percent is due to an increase in the capital-output ratio and 100 percent due to TFP. ${ }^{11}$

In other words, depending on the definition of capital deepening, the same observations can lead to vastly different conclusions of the role of "capital deepening" versus TFP growth.

If, as we will do in this paper, we define capital deepening as an increase in the capitaloutput ratio, and focus on the change in the growth of GDP per worker, most of the literature finds that convergence is driven by TFP — not capital deepening. For example, Klenow and Rodríguez-Clare (1997) found that the growth in output per worker in the three economies, Hong Kong SAR, South Korea, and Taiwan Province of China, out of the four East Asian miracles discussed in Young (1995), came mostly from productivity gains while Young argued that growth in these economies was largely due to factor accumulation. Klenow and Rodríguez-Clare (1997) argued that the increases in the capital were not exogenous but the result of higher level of productivity.

Similarly, Easterly and Levine (2001) found that difference in the total factor productivity, rather than factor accumulation, accounts for most of the income and growth difference across countries and national policies are closely associated with growth in the long-run.

\footnotetext{
${ }^{9}$ This follows from equation (14).

${ }^{10}$ This follows from equation (15).

${ }^{11}$ This follows from equation (16).
} 


\subsection{GDP growth}

We start with decomposing changes in GDP growth. Taking logs and differences, we can write equation (4) as

$$
y=\alpha k+(1-\alpha) l+(1-\alpha) h+g
$$

where $x=\Delta \log (x)$.

Figure 4.1 shows this decomposition for Poland and Mexico. Poland grew faster because its capital stock grew faster and because of a more rapid increase of TFP. This was partly offset by lower employment growth.

Figure 4.2 shows a cross-country comparison of the decomposition of average annual GDP growth between 1995 and 2018 for a large group of countries. Faster growing countries tend to have both faster TFP growth and faster growth of the capital stock.

In Penn World Tables, the improvement in human capital is derived from a formula that is based on average years of schooling. If this overstates the improvement in human capital, it will understate TFP growth. We therefore also show the same charts, but with the contribution of TFP growth and human capital combined (Figures 4.1A and 4.1B).

\subsection{GDP per capita growth and the capital-labor ratio}

Next we look at decomposing changes in GDP per capita. Taking differences we can rewrite equation (7) as:

$$
y-p=l-p+\alpha(k-l)+(1-\alpha) h+g
$$

The change in log GDP per capita depends on the change in the employment rate, the change in the capital labor ratio, the contribution of human capital, and TFP growth.

Figure 4.3 shows the decomposition for Mexico and Poland. It shows that the capitallabor ratio in Mexico has not grown much, nor has TFP growth.

Figure 4.4 shows a cross-country comparison. Fast growing countries tend to have faster TFP growth. The role of the capital-labor ratio is less clear-cut. Slow growing countries tend to have the smallest increase in the capital-labor ratio. However, there is a group of countries in the middle that had a very sharp increase in the capital-labor ratio.

Figures $4.3 \mathrm{~A}$ and $4.4 \mathrm{~A}$ are the same as figures 4.3 and 4.4 , but with contribution of TFP and human capital combined.

\subsection{GDP per capita growth and the capital-output ratio}

For the reasons discussed before, equation (15) exaggerates the contribution of capital deepening. Taking differences we can rewrite equation (10) as

$$
y-p=l-p+\left(\frac{\alpha}{1-\alpha}\right)(k-y)+h+\frac{g}{1-\alpha}
$$


Per capita GDP growth can be attributed to four factors: an increase in the employment to population ratio $(l-p)$, an increase of human capital $(h)$, an increase of $\operatorname{TFP}(g)$, and capital deepening.

Figure 4.5 shows the decomposition for Mexico and Poland. This suggests that almost all of the growth difference between Poland and Mexico is due to higher TFP growth in Poland. Figure 4.6 shows the cross-country comparison. The fastest growing countries have rapid TFP growth; the slowest have low TFP growth.

Figures $4.5 \mathrm{~A}$ and $4.6 \mathrm{~A}$ are the same as figures 4.3 and 4.4 , but with contribution of TFP and human capital combined.

Figure 4.7 confirms that that cross country differences in growth are not associated with differences in capital deepening. They are associated with differences in TFP and human capital growth. 
Figure 4.1. Decomposition of Change in Real GDP, 1995-2017
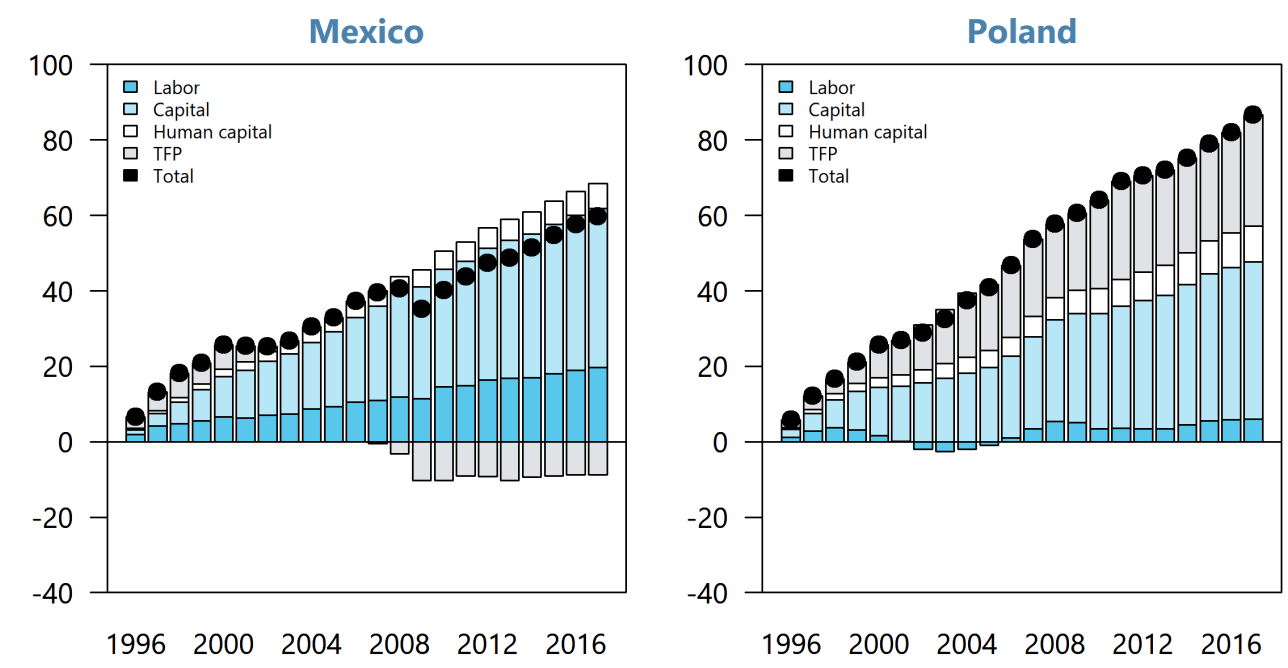

Source: Penn World Tables 9.1

Figure 4.2. Decomposition GDP Growth, 1995-2017

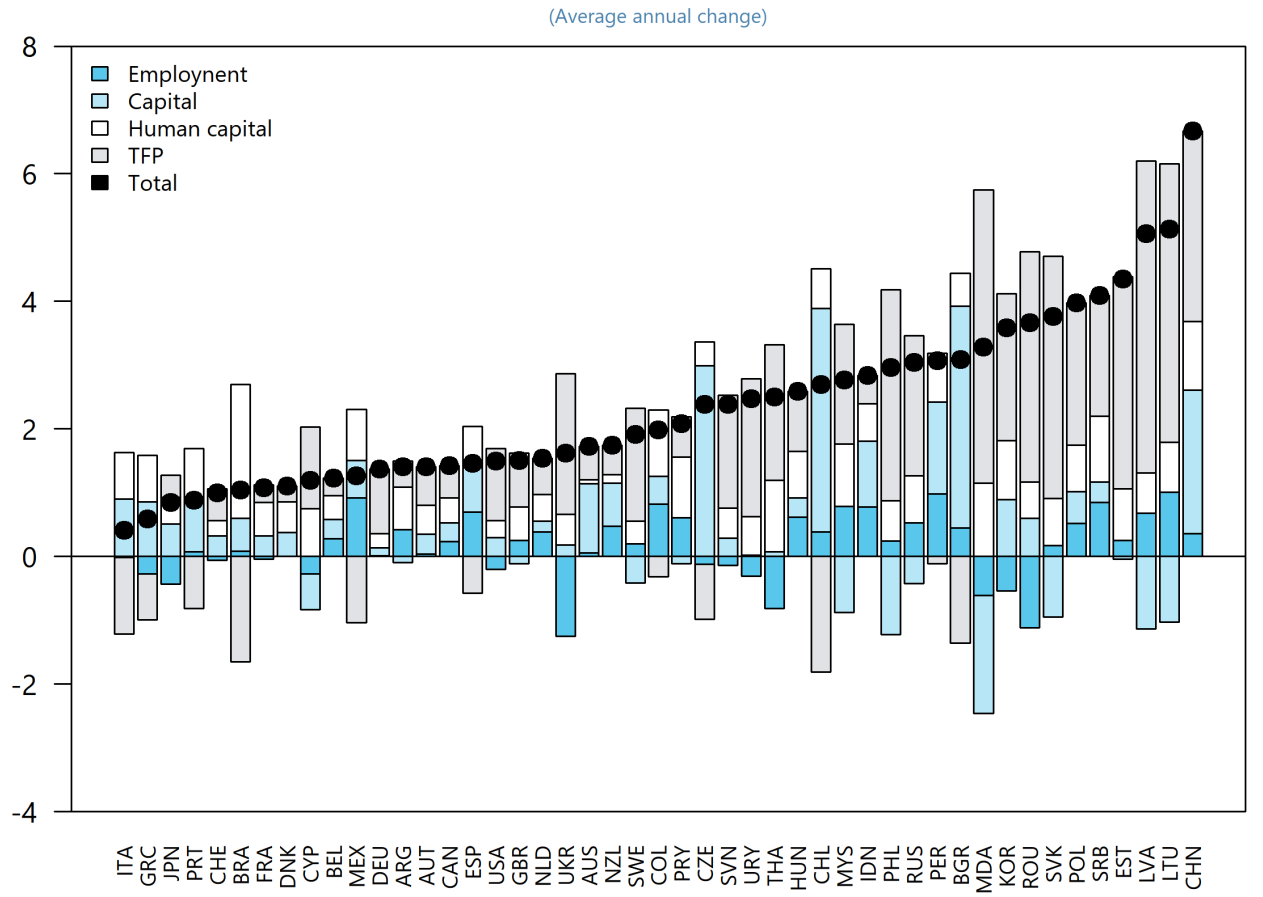


Figure 4.1A. Decomposition of Change in Real GDP, 1995-2017
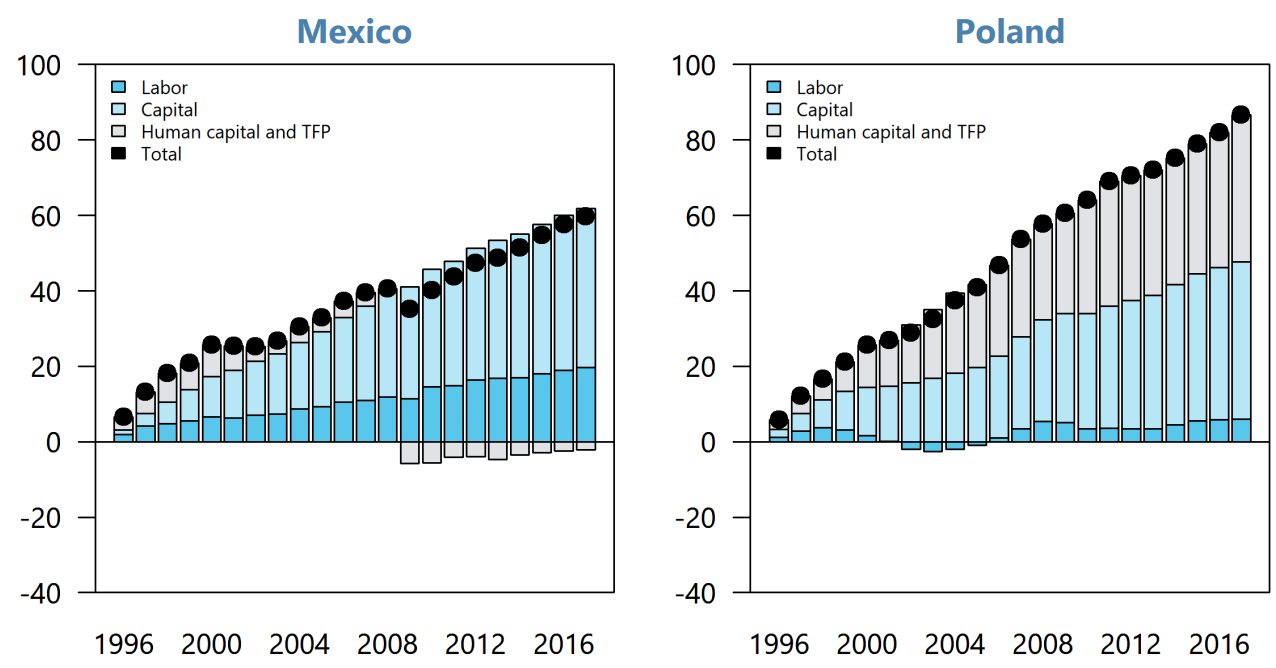

Source: Penn World Tables 9.1.

Figure 4.2A. Decomposition GDP Growth, 1995-2017

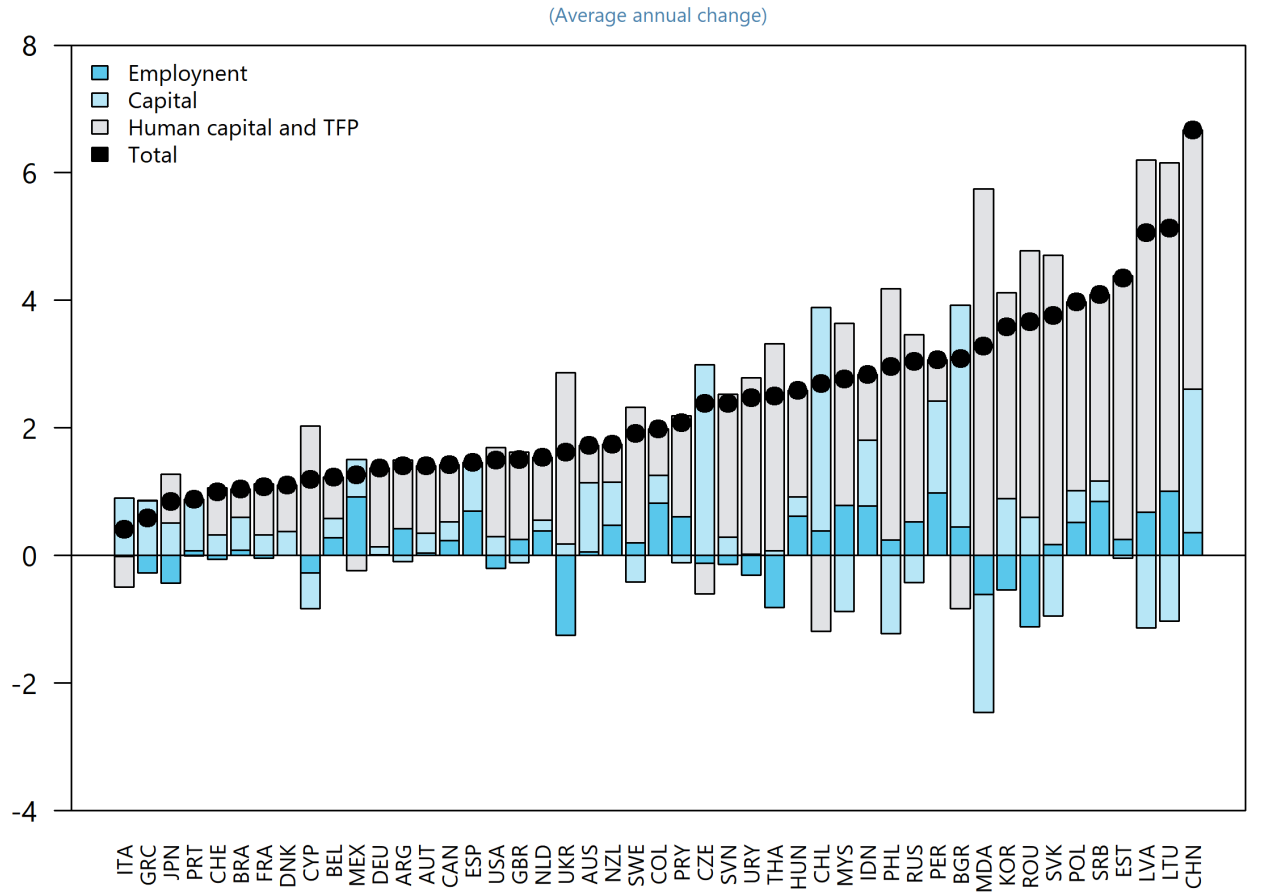


Figure 4.3. Decomposition of Change in Real GDP per Capita, 1990-2018
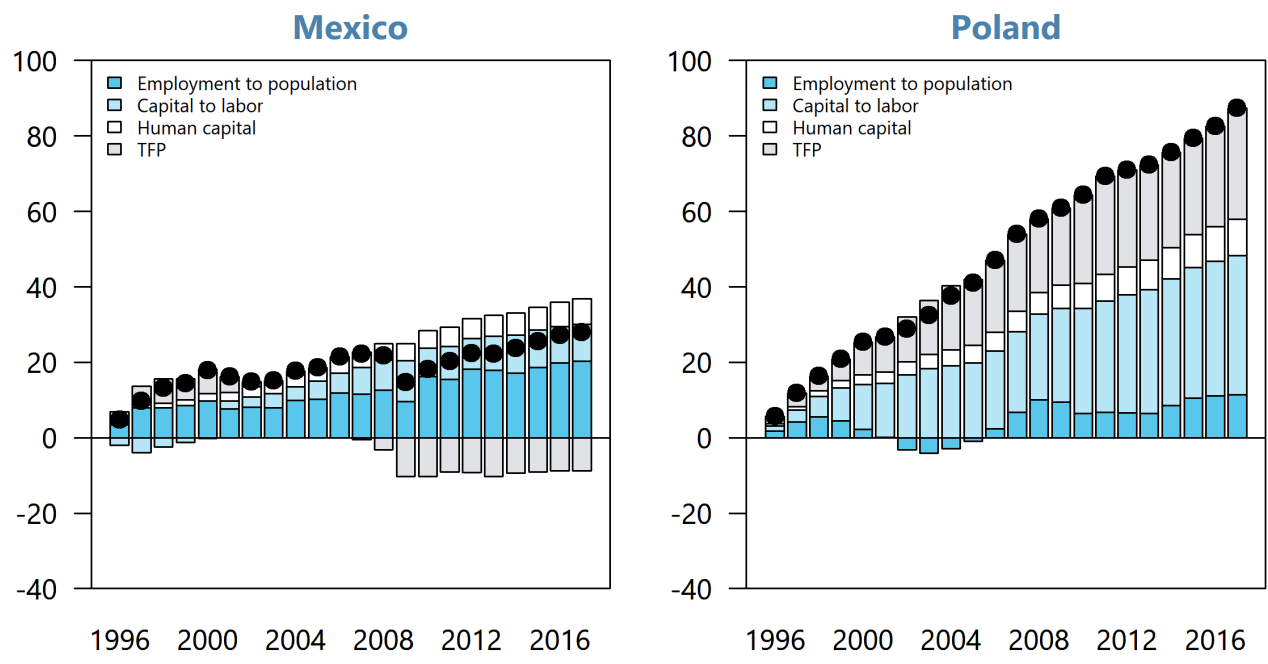

Source: Total Economy database

Figure 4.4. Decomposition GDP per capita Growth, 1995-2017

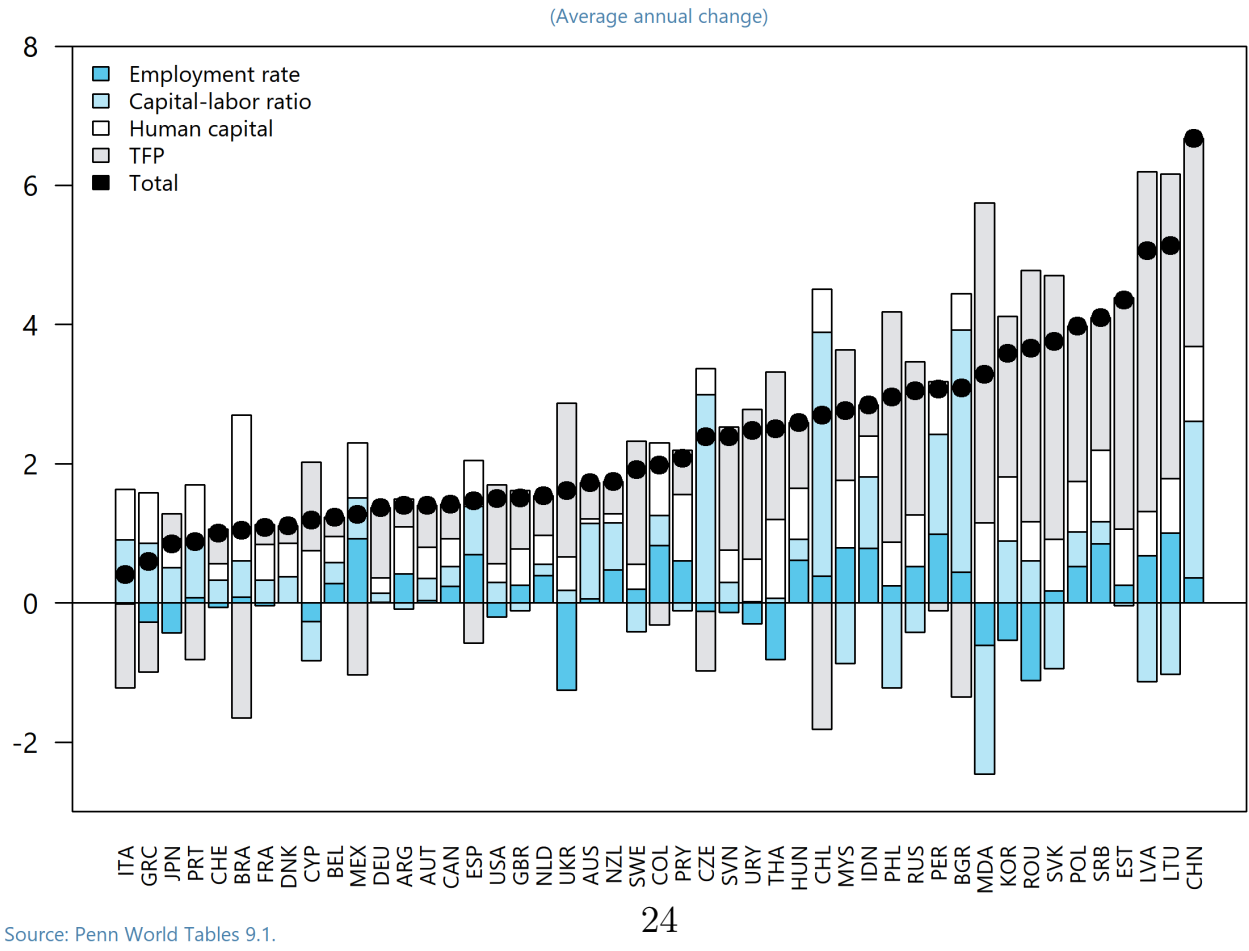

CInternational Monetary Fund. Not for Redistribution 
Figure 4.3A. Decomposition of Change in Real GDP per Capita, 1990-2018
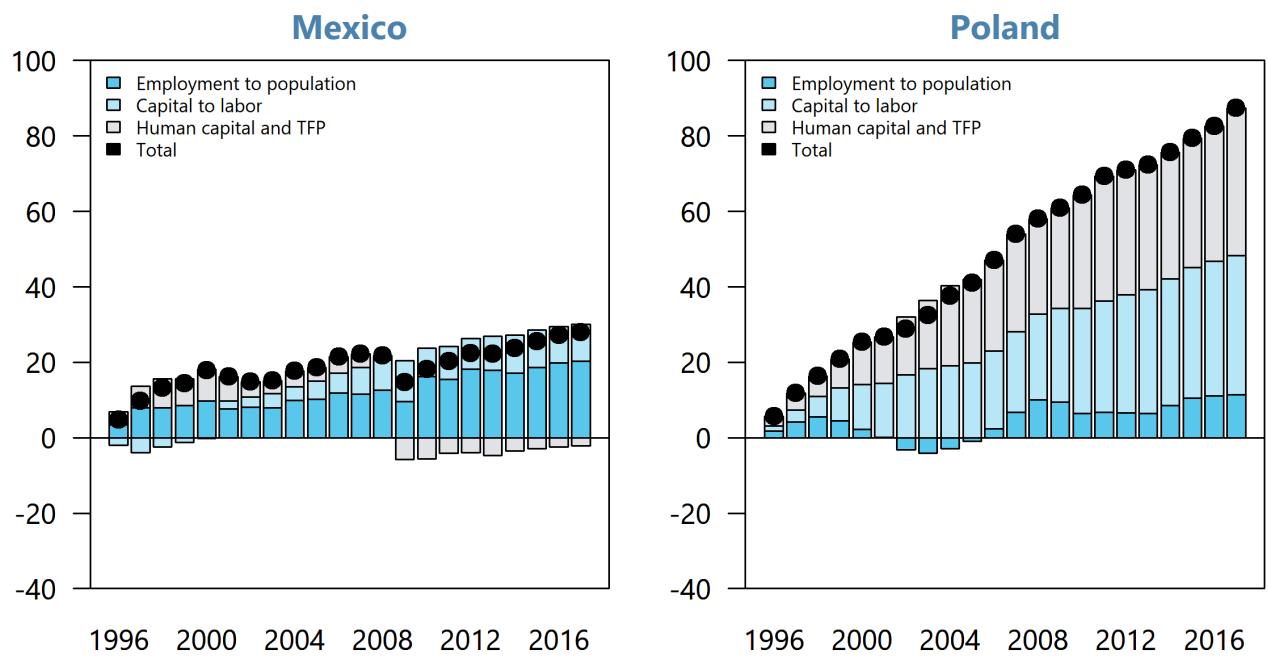

Source: Total Economy database

Figure 4.4A. Decomposition GDP per capita Growth, 1995-2017

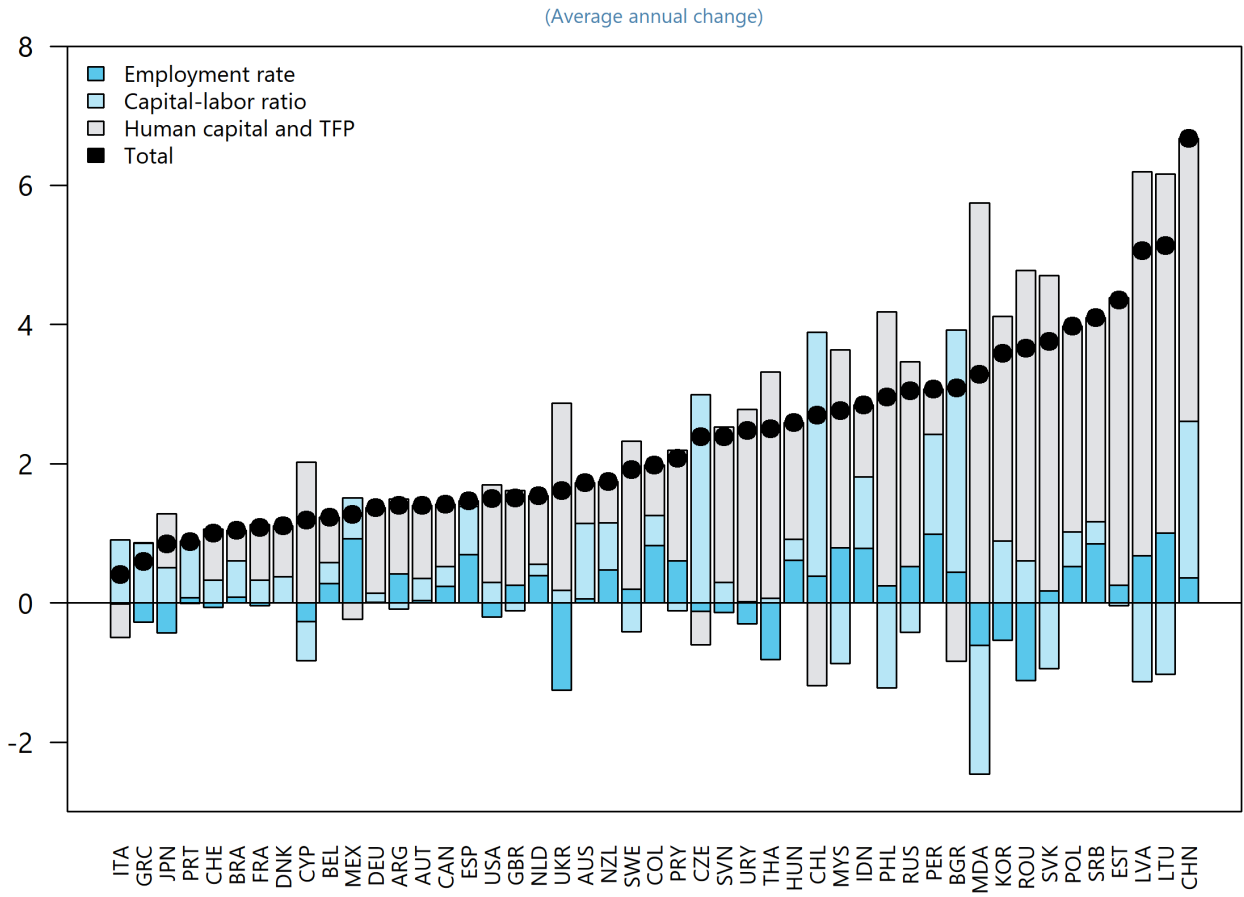


Figure 4.5. Decomposition of Change in Real GDP per Capita, 1995-2017
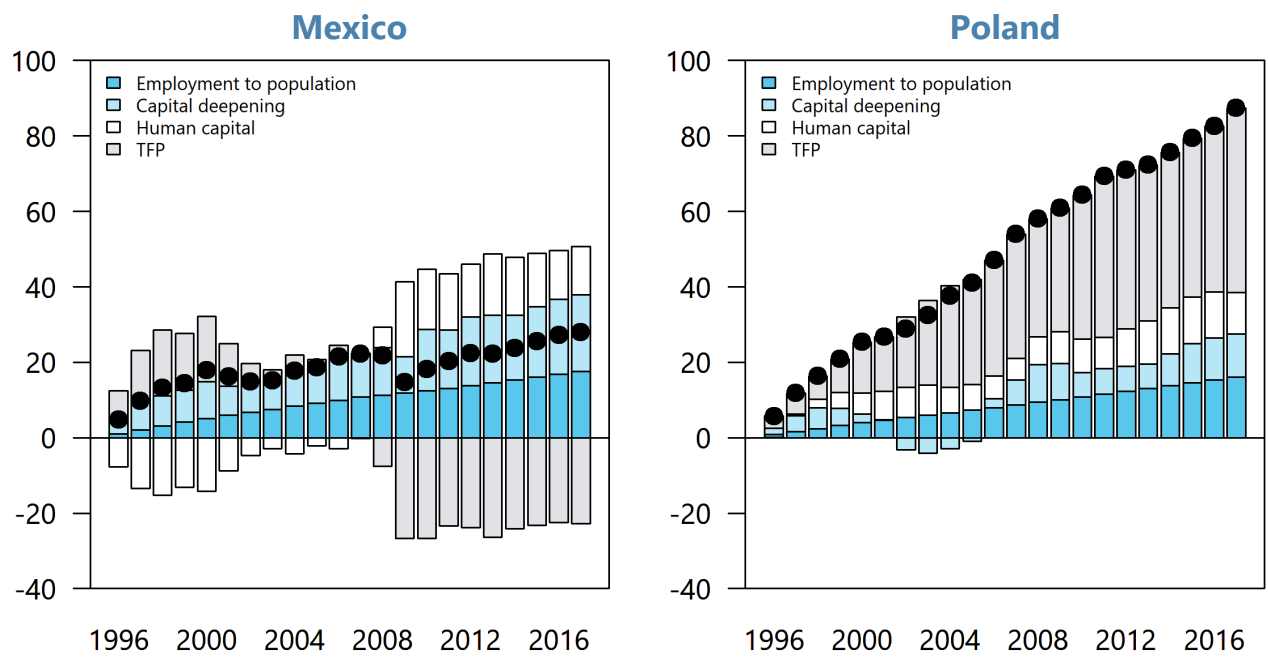

Source: Penn World Tables 9.1

Figure 4.6. Decomposition GDP per Capita Growth, 1995-2018

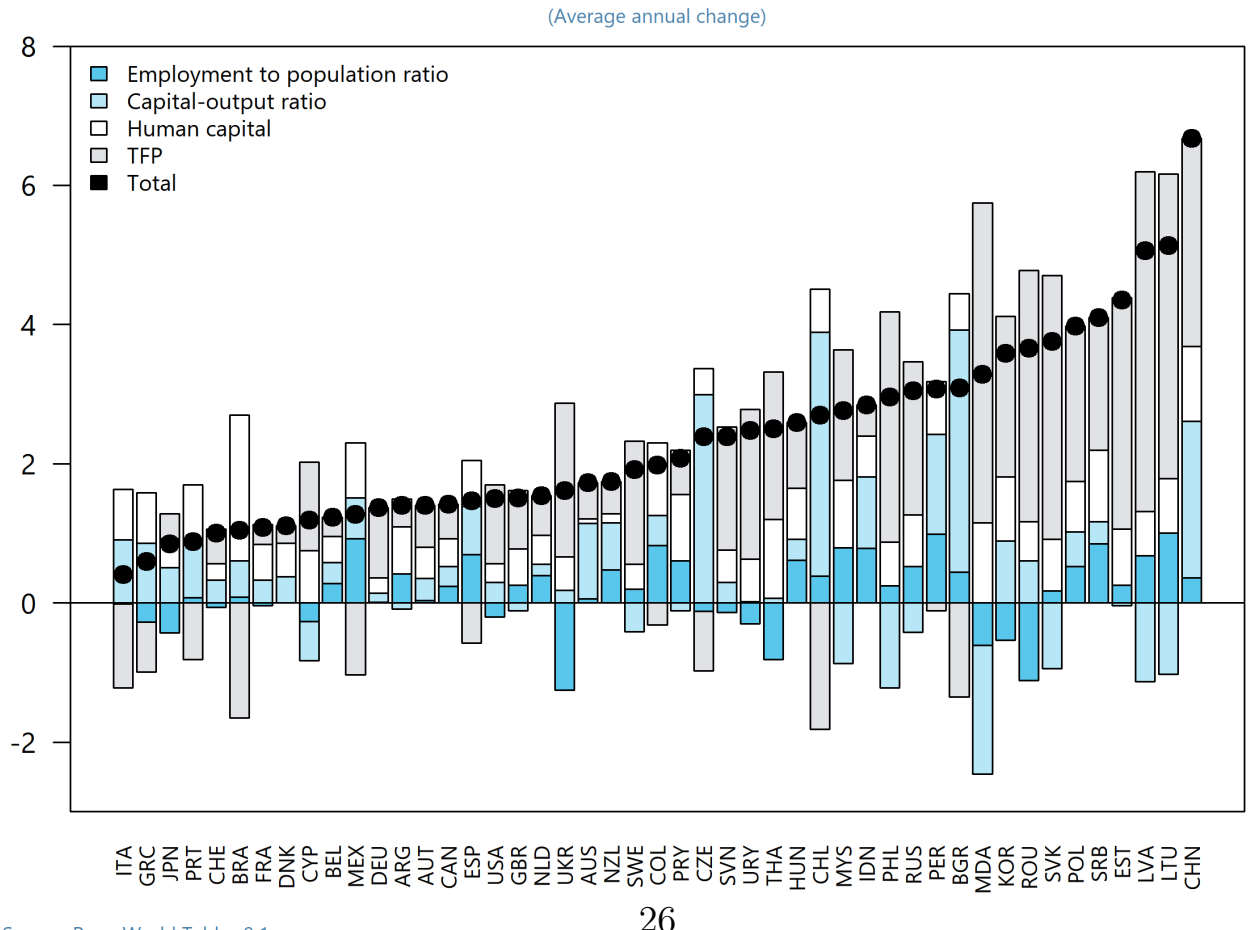



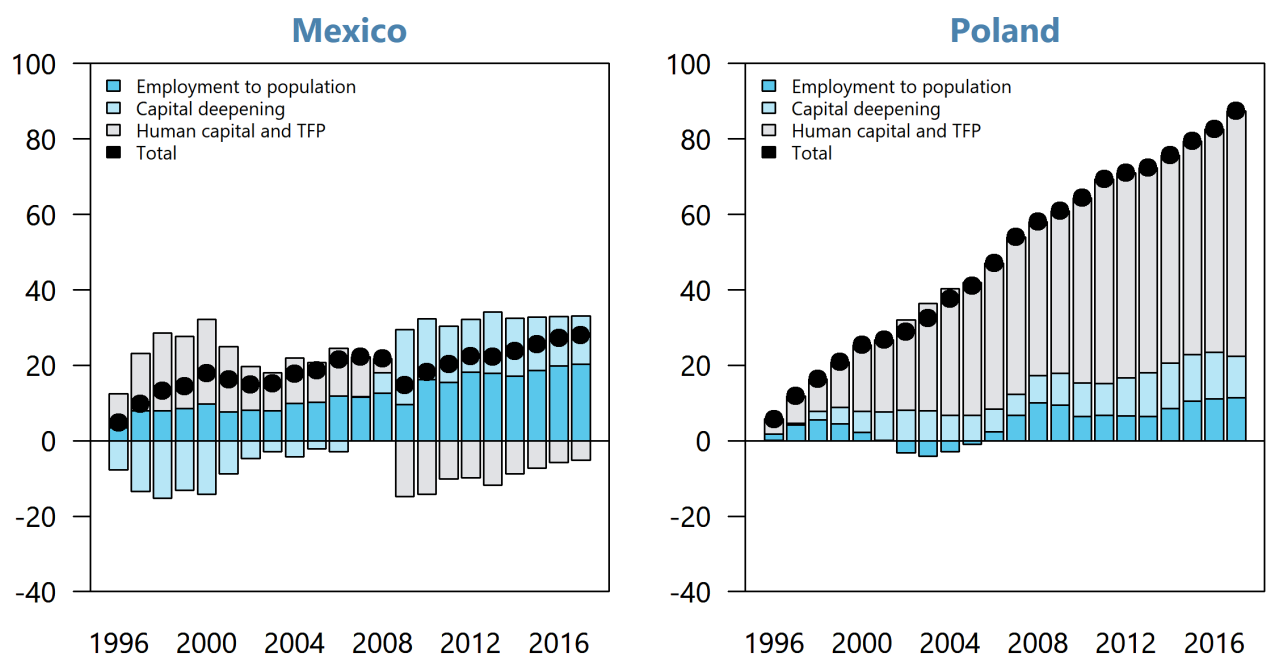

Source: Penn World Tables 9.1

Figure 4.6A. Decomposition GDP per Capita Growth, 1995-2017

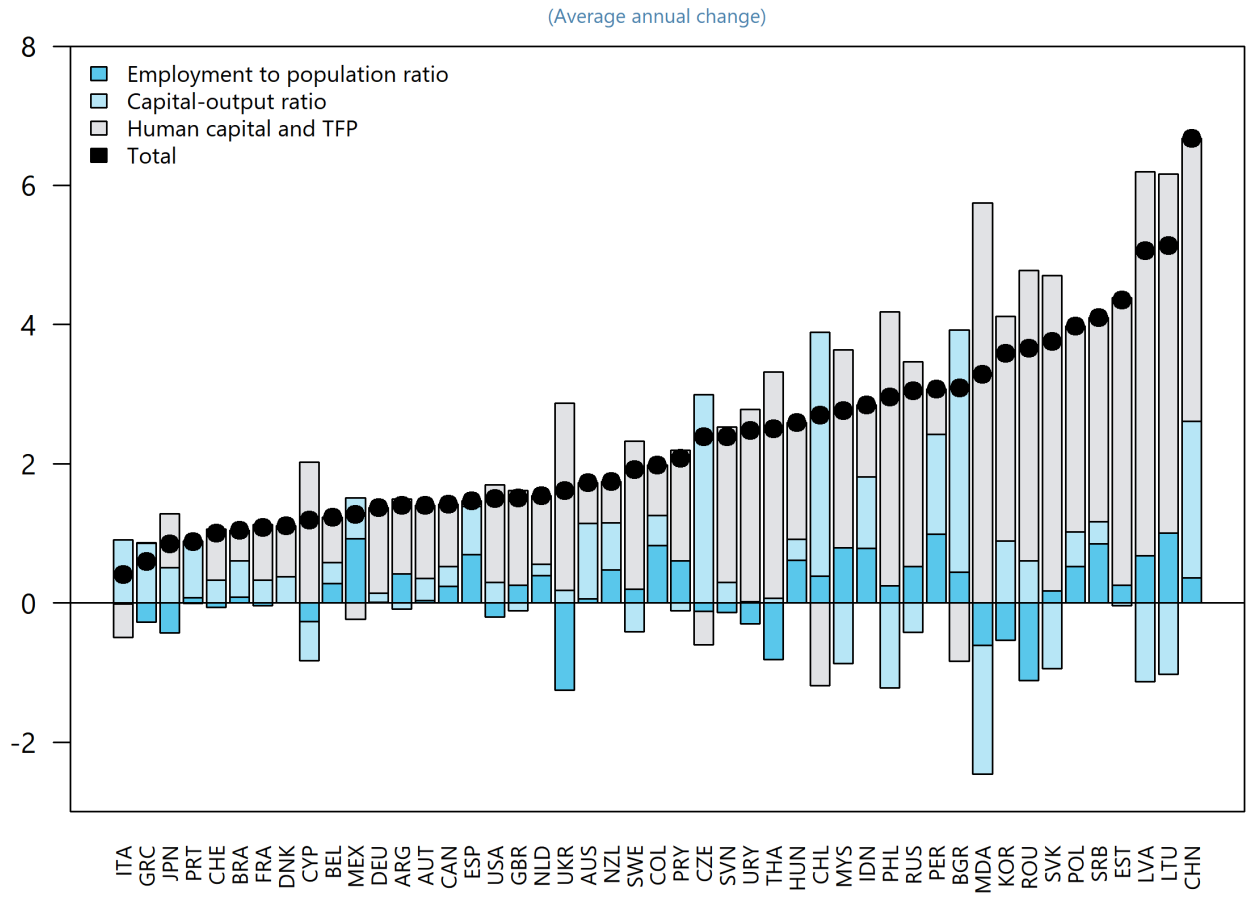


Figure 4.7. The Role of Capital Deepening, TFP and Human Capital in GDP per Capita Growth
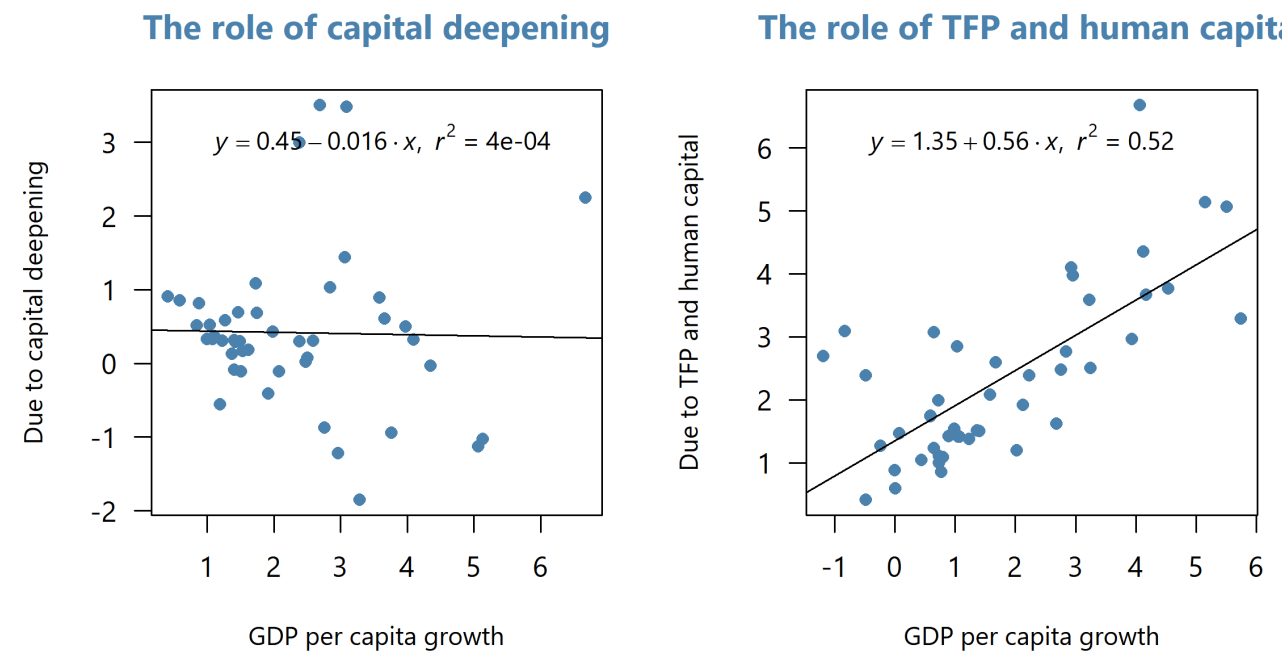

Source: Penn World Tables 9.1. 
5 TFP: the link with Institutions and Human Capital

We next show that cross-country differences of TFP are associated with cross-country differences in human capital, governance and business climate indicators. Countries with high human capital, strong governance and favorable business climates have higher TFP; countries with low human capital, weak governance and poor business climates lower TFP.

\subsection{Institutions and TFP}

Research has found that better institutions are associated with higher GDP per capita levels and faster convergence. The explanation may be that better institutions raise incentives for both factor accumulation and innovation. They also play an important role in fostering technological change as well as improving the overall allocative efficiency of factors of production (Acemoglu et al., 2005, Hall and Jones, 1999, Joilson and Edinaldo, 2012, North, 1990). Tebaldia and Elmslieb (2013) find that institutional arrangements explain much of the cross-country variations in patent production, a proxy for technological innovation.

Better governance and business climate indicators are associated with higher TFP levels (Fadiran and Akanbi, 2017, Giang et al., 2018, Kim and Loayza, 2017, Veeramani and Bishwanath, 2004). Similarly, poor governance is associated with low TFP, as it leads to increased distortions and resource misallocations (Restuccia and Rogerson, 2013).

In an empirical study, Nguyen and Jamarillo (2014), showed that the return to innovation at firm level is higher in countries with better institutions (namely rule of law, regulatory quality and protection of property rights). They find that the difference in the return to innovation between Latin American countries with better institutions (especially protection of property right) and Latin American countries with worse institutions is particularly large.

Indicators of institutional strength show large cross-country differences. According to the governance indicators compiled by the World Bank, advanced countries tend to have higher scores on government effectiveness and rule of law than developing and emerging market countries (Figure 5.1). Figure 5.1 shows the score for the average indicator; figure 5.2 for the various subindicators. Countries with higher governance scores tend to have higher TFP levels (Figure 5.3).

The global competitiveness indicators produced by the World Economic Forum show a similar picture (Figure 5.4). Figure 5.5 shows the scores on the subindicators. There is a strong link between these indicators of institutional strength and TFP levels. Figure 5.6 shows that countries that score better on the competitiveness indicators tend to have higher TFP. 


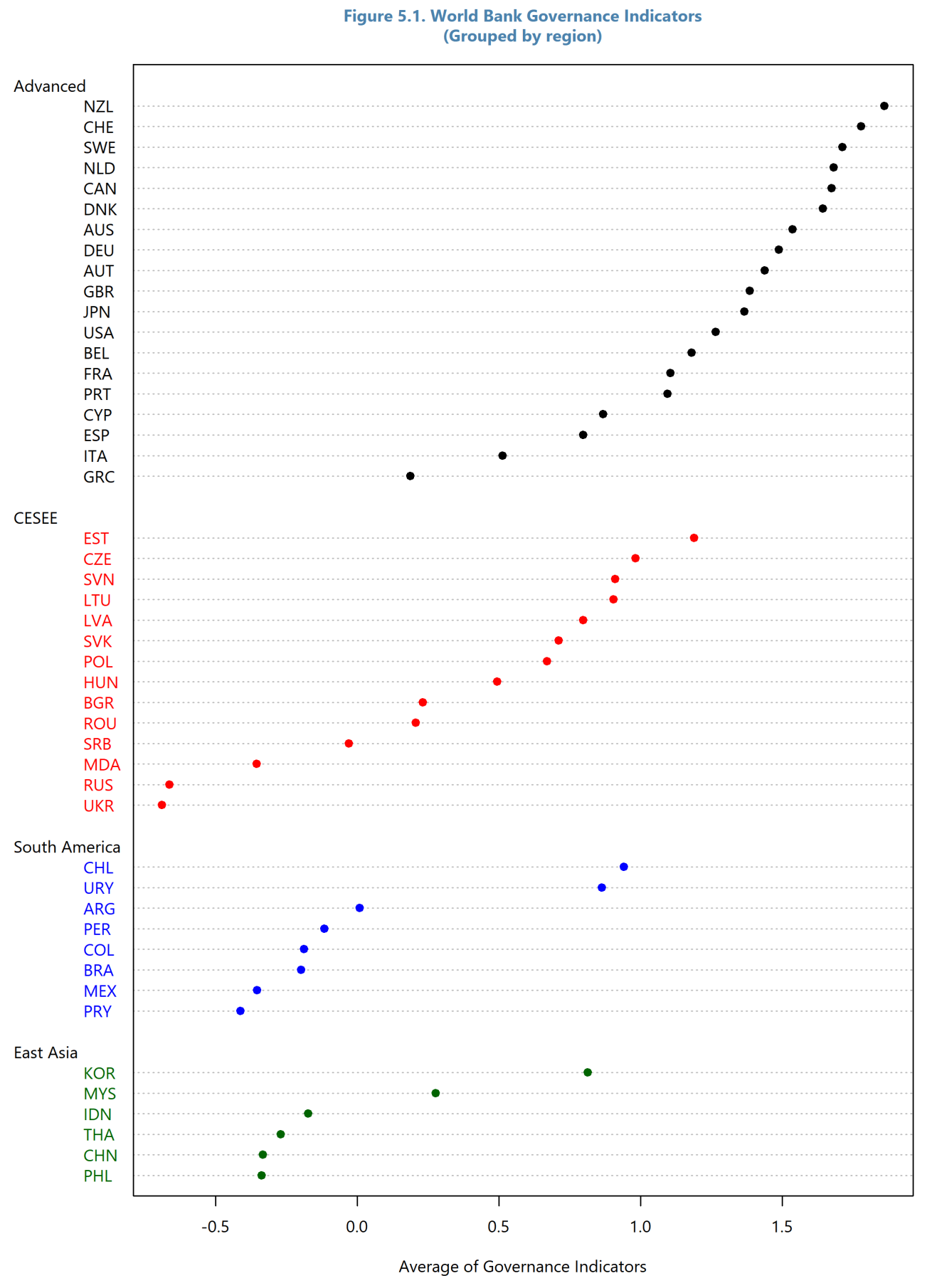

Source: World bank governance indicators, 2019 


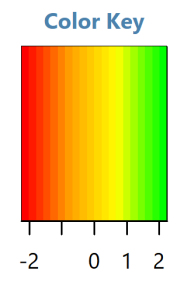

Figure 5.2. World Bank Governance Indicators

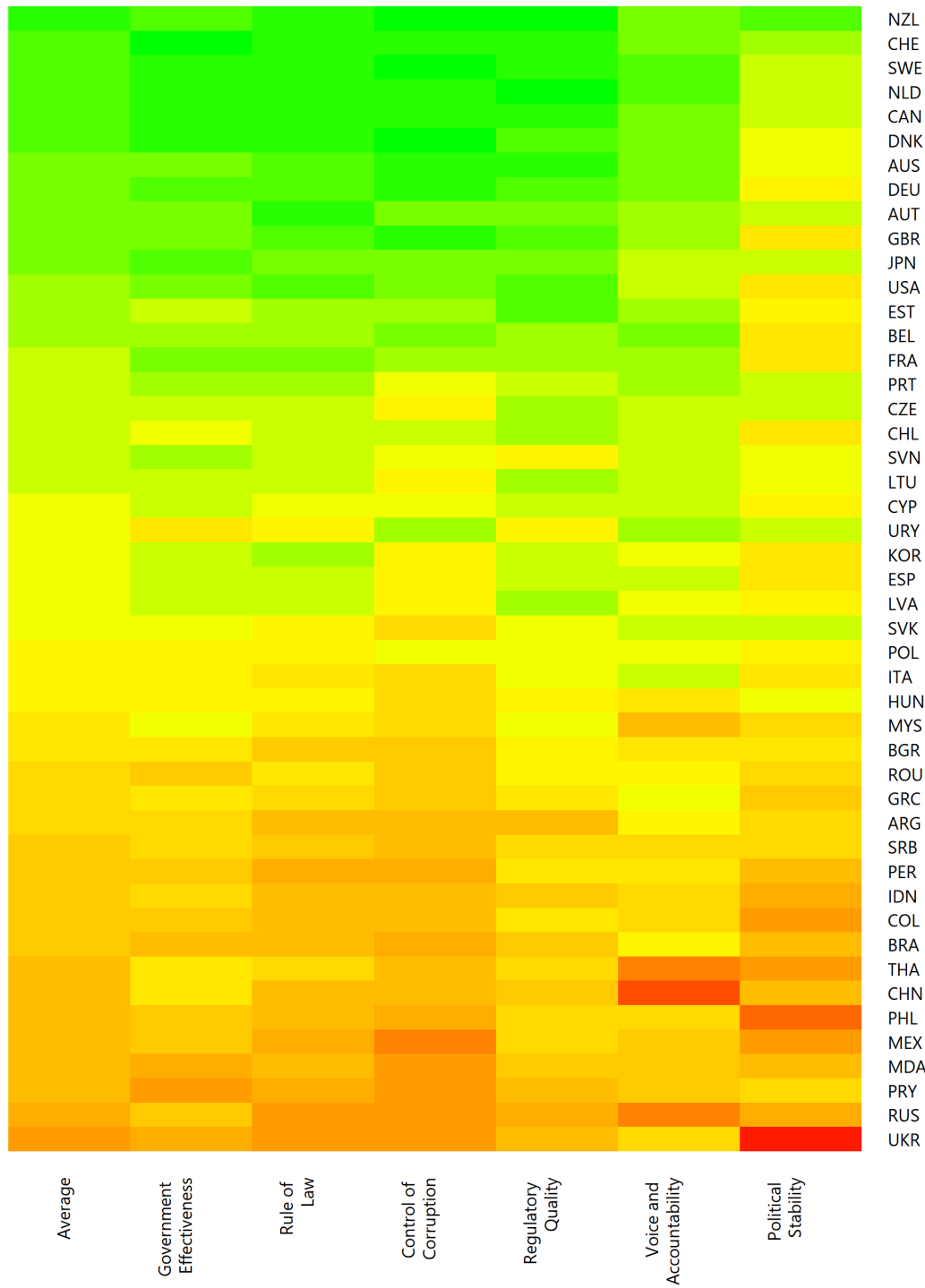

Source: World bank governance indicators, 2019 
Figure 5.3. Correlations of Governance Indicators with TFP
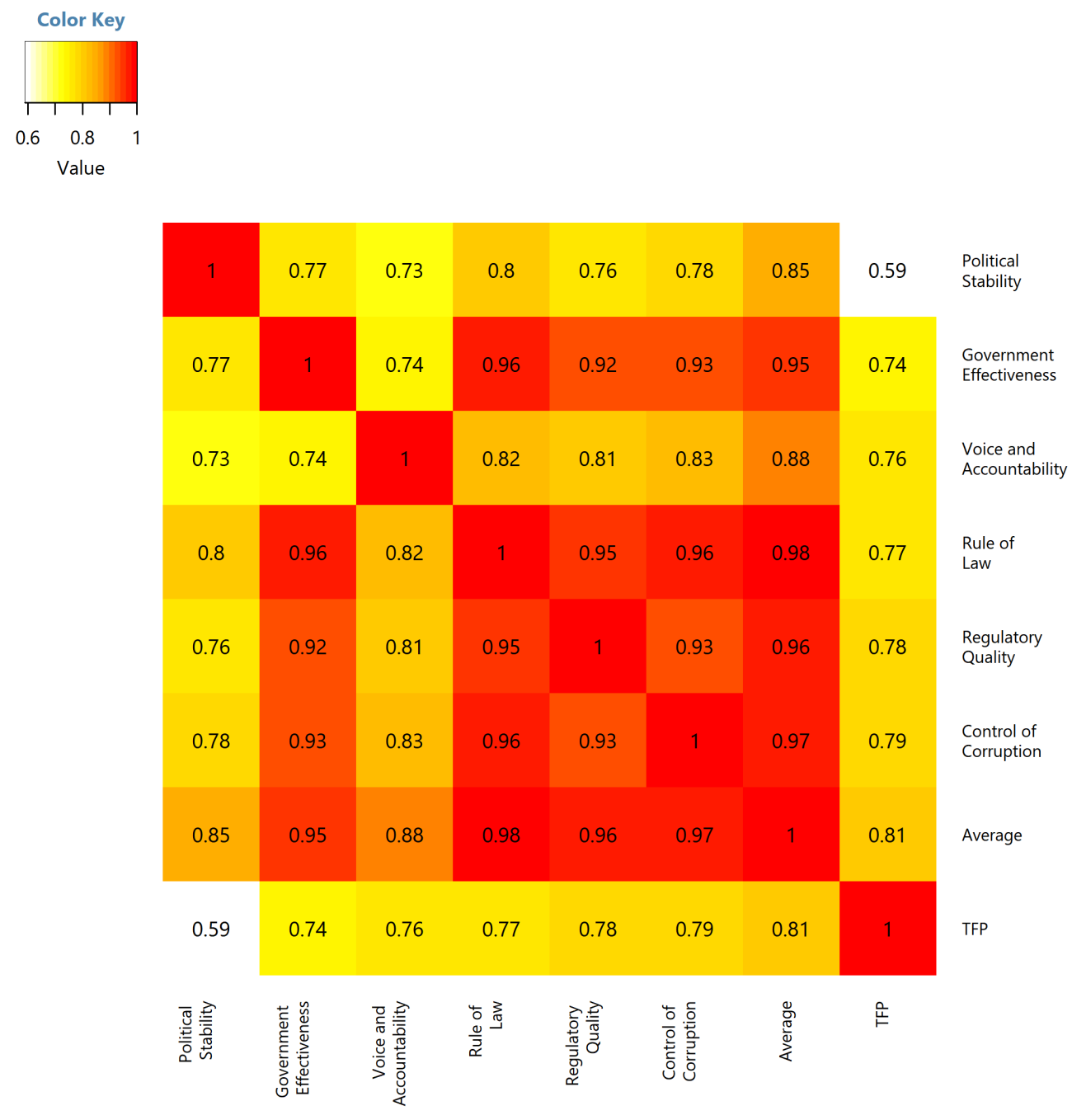

Source: World bank governance indicators, 2019 
Figure 5.4. World Economic Forum Global Competitiveness Indicators (Grouped by region)

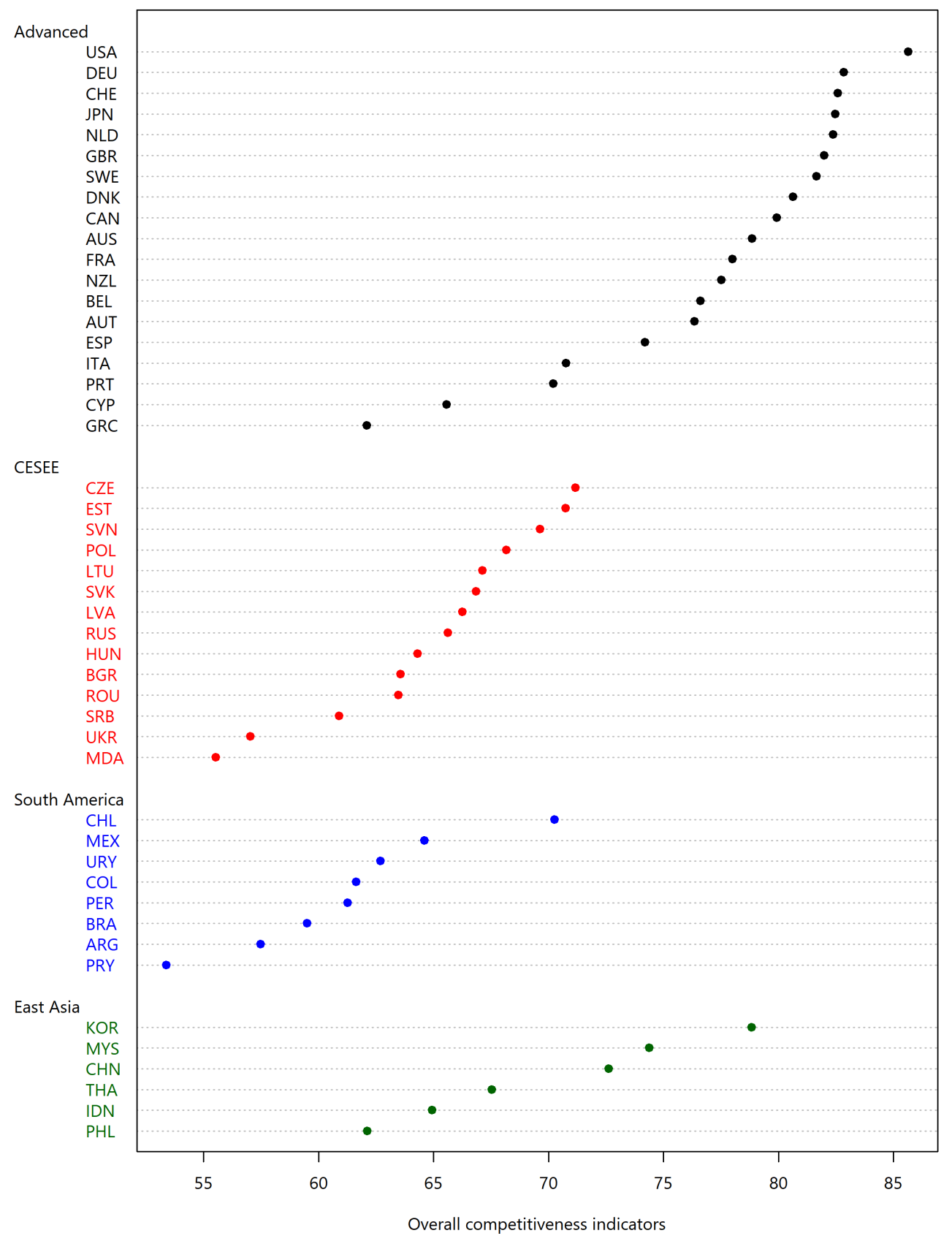

Source: World bank governance indicators, 2019 


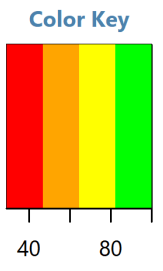

Figure 5.5. Global Competitiveness Indicator Scores

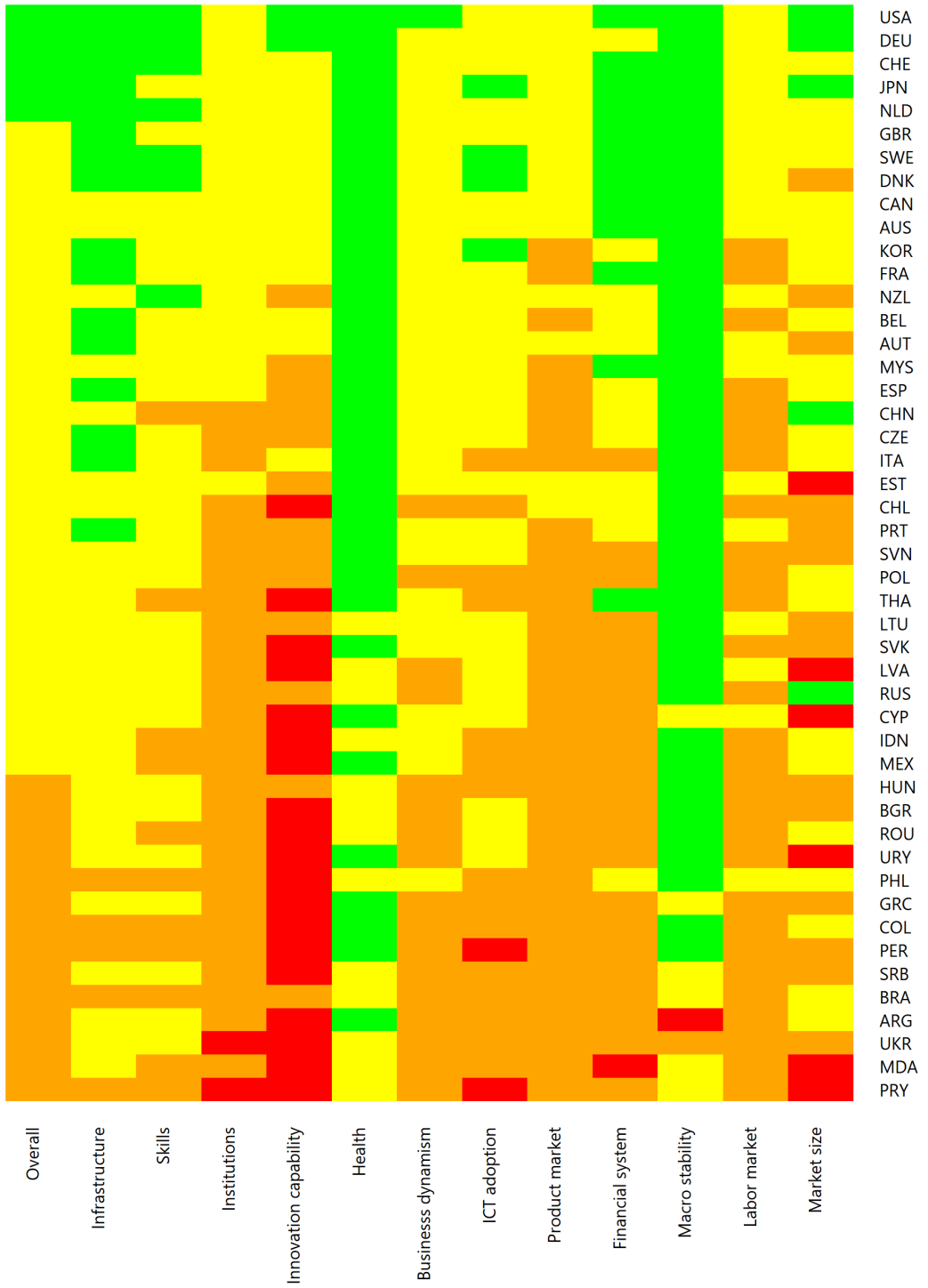

Source: World Economic Forum, The Global Competitiveness Index 4.0 2018 Dataset. 
Figure 5.6. Correlations of Competitiveness Indicators with TFP

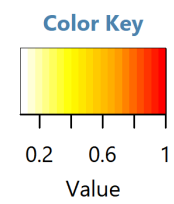

\begin{tabular}{|c|c|c|c|c|c|c|c|c|c|c|c|c|c|c|}
\hline 1 & 0.21 & 0.08 & 0.54 & 0.12 & 0.39 & 0.19 & 0.4 & 0.2 & 0.53 & 0.48 & 0.15 & 0.18 & 0.21 & Market size \\
\hline 0.21 & 1 & 0.46 & 0.61 & 0.58 & 0.65 & 0.39 & 0.51 & 0.61 & 0.52 & 0.69 & 0.49 & 0.6 & 0.43 & Macro stability \\
\hline 0.08 & 0.46 & 1 & 0.47 & 0.57 & 0.6 & 0.36 & 0.66 & 0.48 & 0.64 & 0.69 & 0.66 & 0.71 & 0.44 & ICT adoption \\
\hline 0.54 & 0.61 & 0.47 & 1 & 0.72 & 0.83 & 0.6 & 0.68 & 0.71 & 0.81 & 0.89 & 0.65 & 0.78 & 0.57 & Financial system \\
\hline 0.12 & 0.58 & 0.57 & 0.72 & 1 & 0.85 & 0.4 & 0.6 & 0.83 & 0.7 & 0.81 & 0.84 & 0.86 & 0.62 & Labor market \\
\hline 0.39 & 0.65 & 0.6 & 0.83 & 0.85 & 1 & 0.51 & 0.73 & 0.82 & 0.82 & 0.92 & 0.82 & 0.85 & 0.62 & Businesss dynamism \\
\hline 0.19 & 0.39 & 0.36 & 0.6 & 0.4 & 0.51 & 1 & 0.69 & 0.6 & 0.66 & 0.68 & 0.54 & 0.65 & 0.63 & Health \\
\hline 0.4 & 0.51 & 0.66 & 0.68 & 0.6 & 0.73 & 0.69 & 1 & 0.67 & 0.9 & 0.88 & 0.79 & 0.77 & 0.7 & Infrastructure \\
\hline 0.2 & 0.61 & 0.48 & 0.71 & 0.83 & 0.82 & 0.6 & 0.67 & 1 & 0.73 & 0.83 & 0.79 & 0.86 & 0.7 & Product market \\
\hline 0.53 & 0.52 & 0.64 & 0.81 & 0.7 & 0.82 & 0.66 & 0.9 & 0.73 & 1 & 0.95 & 0.82 & 0.83 & 0.71 & Innovation capability \\
\hline 0.48 & 0.69 & 0.69 & 0.89 & 0.81 & 0.92 & 0.68 & 0.88 & 0.83 & 0.95 & 1 & 0.85 & 0.91 & 0.73 & Overall \\
\hline 0.15 & 0.49 & 0.66 & 0.65 & 0.84 & 0.82 & 0.54 & 0.79 & 0.79 & 0.82 & 0.85 & 1 & 0.89 & 0.74 & Skills \\
\hline 0.18 & 0.6 & 0.71 & 0.78 & 0.86 & 0.85 & 0.65 & 0.77 & 0.86 & 0.83 & 0.91 & 0.89 & 1 & 0.76 & Institutions \\
\hline 0.21 & 0.43 & 0.44 & 0.57 & 0.62 & 0.62 & 0.63 & 0.7 & 0.7 & 0.71 & 0.73 & 0.74 & 0.76 & 1 & TFP \\
\hline 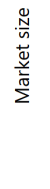 & 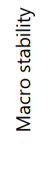 & $\begin{array}{l}\overline{0} \\
\frac{0}{0} \\
\frac{0}{0} \\
\frac{\sigma}{0} \\
\underline{v}\end{array}$ & 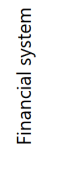 & 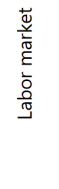 & 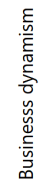 & 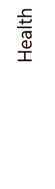 & 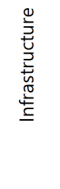 & 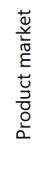 & 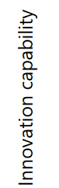 & $\begin{array}{l}\overline{\overline{0}} \\
\overline{0} \\
\overline{0}\end{array}$ & $\frac{n}{\bar{m}}$ & 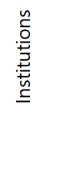 & 论 & \\
\hline
\end{tabular}




\subsection{Human Capital and TFP}

According to the economic literature, higher human capital is associated with higher income levels and faster growth. Having more skilled people facilitates a more rapid adoption of new technologies and production processes. ${ }^{12}$ It also facilitates the accumulation of knowledge, either through learning by doing (Romer, 1986, Stokey, 1988, Young, 1991) or through R\&D (Aghion and Howitt, 1992, Grossman and Helpman, 1991) or idea gaps (Romer, 1993).

Test scores (human capital output) may matter more than years of schooling (human capital input). Hanushek and Woessmann (2012) showed that differences in test scores (such as PISA) have much stronger explanatory power for growth differentials than years of schooling. Latin American countries score more poorly on test scores for each year of schooling than the average student in the rest of the world. According to Hanushek and Woessmann, poor human capital is one of the key reasons why Latin America has done relatively poorly.

Some authors have argued that institutions are more important than human capital. For example, Acemoglu et al. (2014) stresses that it is the impact of institutions on longrun development is robust, whereas the estimates of the effect of human capital are much reduced when controlling for the effect of institutions.

Two types of human capital indicators are commonly used in the literature:

- One is based on average years of schooling only. ${ }^{13}$ We will refer to this type of indicator as human capital input. The left panel of Figure 5.7 provides a cross-country comparison, based on Penn World Tables 9.1.

- The second focuses on what students have actually learned. We will refer to this type of indicator as human capital output. A well-known example are the OECD Pisa Scores. We will use the World Bank's Human Capital Index, which takes into account both quantity of education (years of schooling) and quality (harmonized test scores). The right panel of Figure 5.7 provides a cross-country comparison of this variable.

Countries with higher human capital input tend to have higher human capital output (Figure 5.8). However, some countries (including China, Japan and Korea) have human capital output scores well above what could be expected given human capital input, while some other countries (including in Latin America) have human capital scores well below what could be expected given human capital input.

Countries with higher human capital levels tend to have higher TFP levels (Figure 5.9). This link exists whether we use human capital input or human capital output. Interestingly, the variation in TPF is higher for countries with high human capital than for countries with low human capital, suggesting that high human capital is a necessary but not sufficient condition for high TFP.

\footnotetext{
${ }^{12}$ This is a central element of both endogenous growth models that stress innovation and ideas (Romer, 1990), and of models of technological diffusion and growth (Nelson and Phelps, 1966).

${ }^{13}$ The human capital index converts the years of schooling to an index.
} 


\subsection{Human Capital, Institutions and TFP}

Human capital and institutions both matter for TFP. Figure 5.10 shows that the only countries with high TFP are those with both high human capital and strong governance. Countries with high human capital and weak governance do not have high TFP. Figure 5.11 provides a similar picture for the link between human capital, the World Economic Forum competitiveness indicators and TFP. Only countries that score high on both indicators have high TFP. 
Figure 5.7. Human Capital, 2017
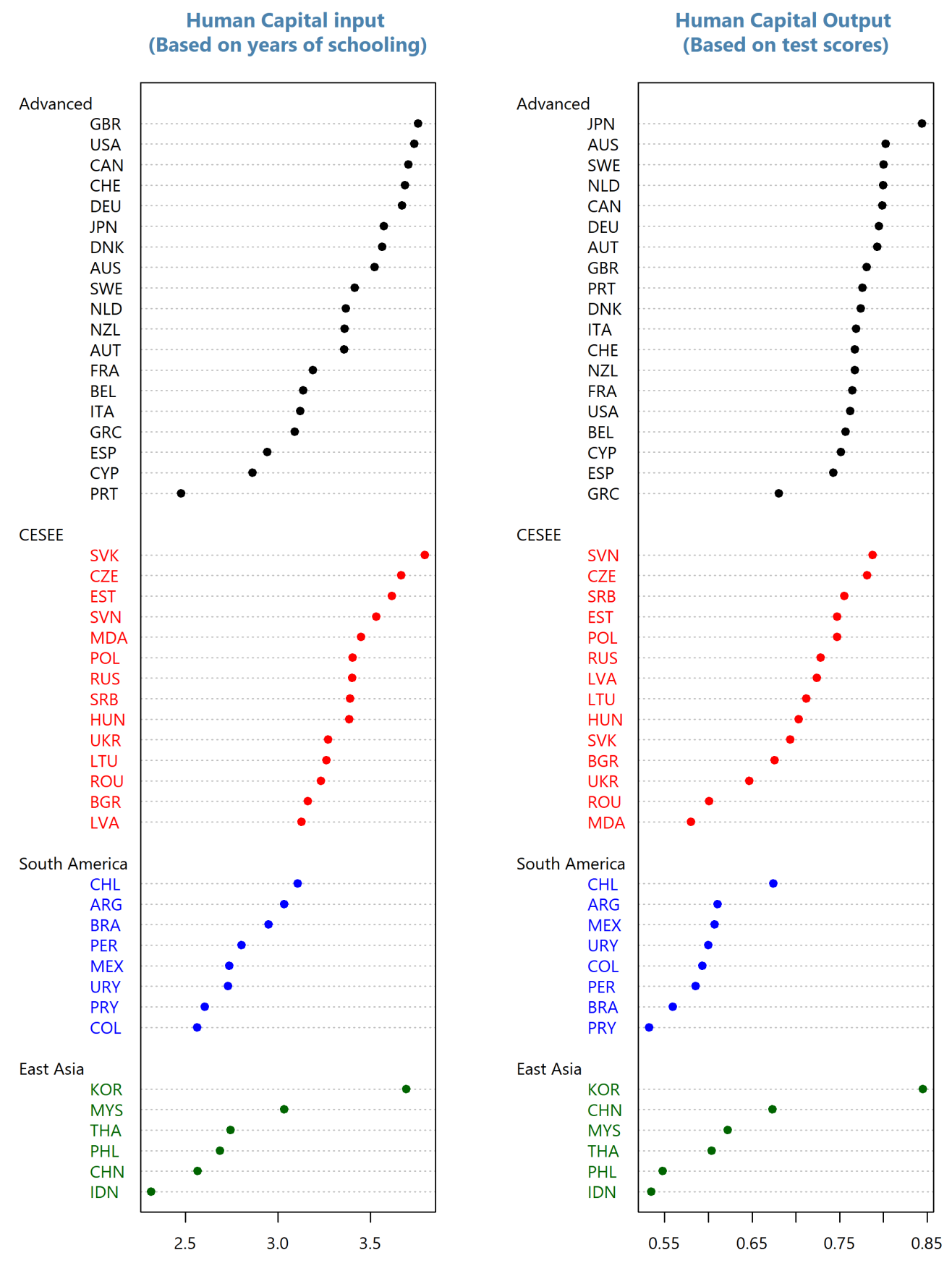

Source: Penn World Tables 9.1 and World Bank- Human capital index 
Figure 5.8. Human Capital Input and Output

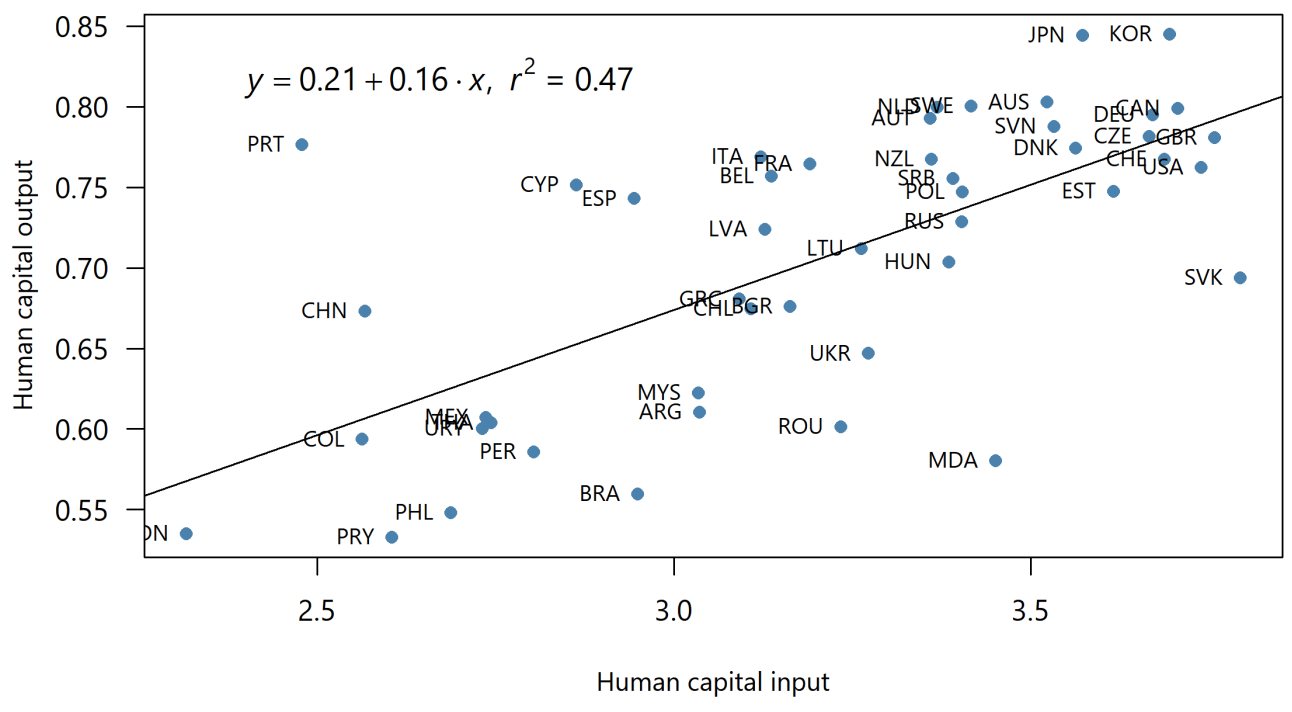

Source: Penn World Tables 9.1 and World Bank 
Figure 5.9. Human Capital and TFP, 2017.

Human Capital, Test Scores based

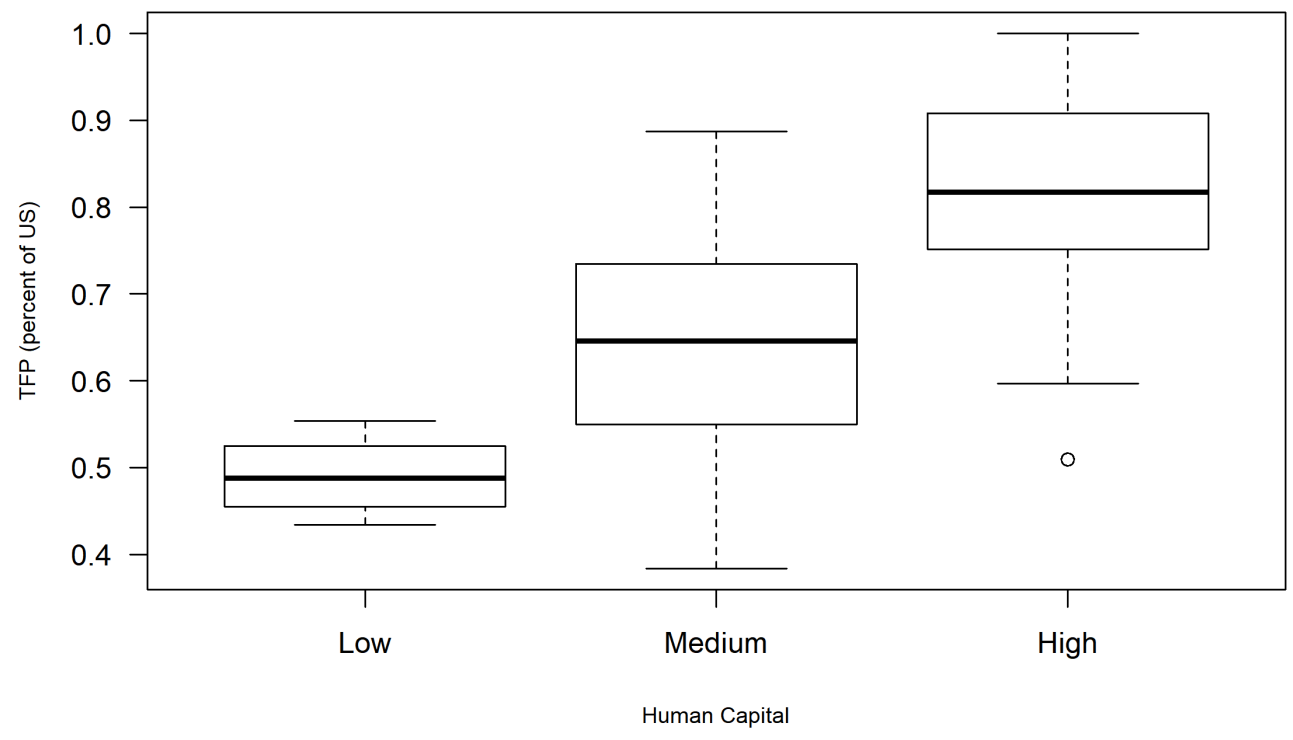

Human Capital, Years of schooling based

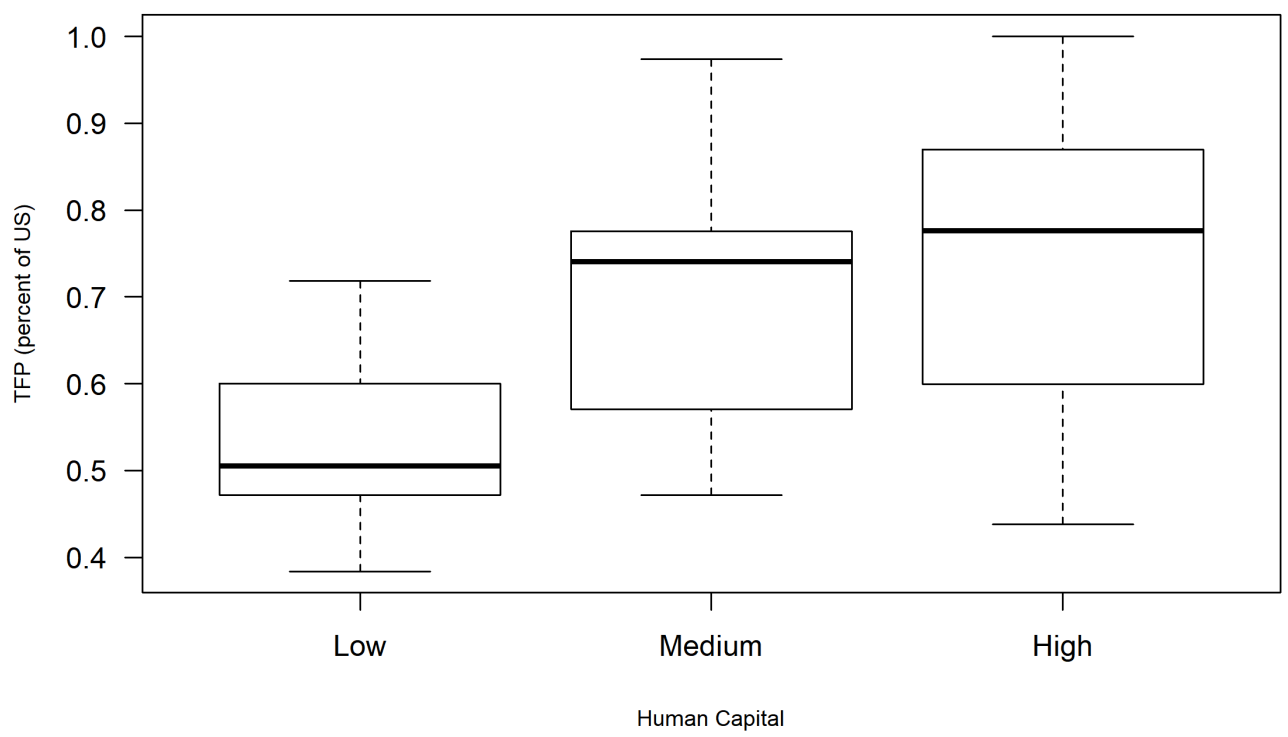

Source: Penn World Tables 9.1 and World Bank Human Capital Index 


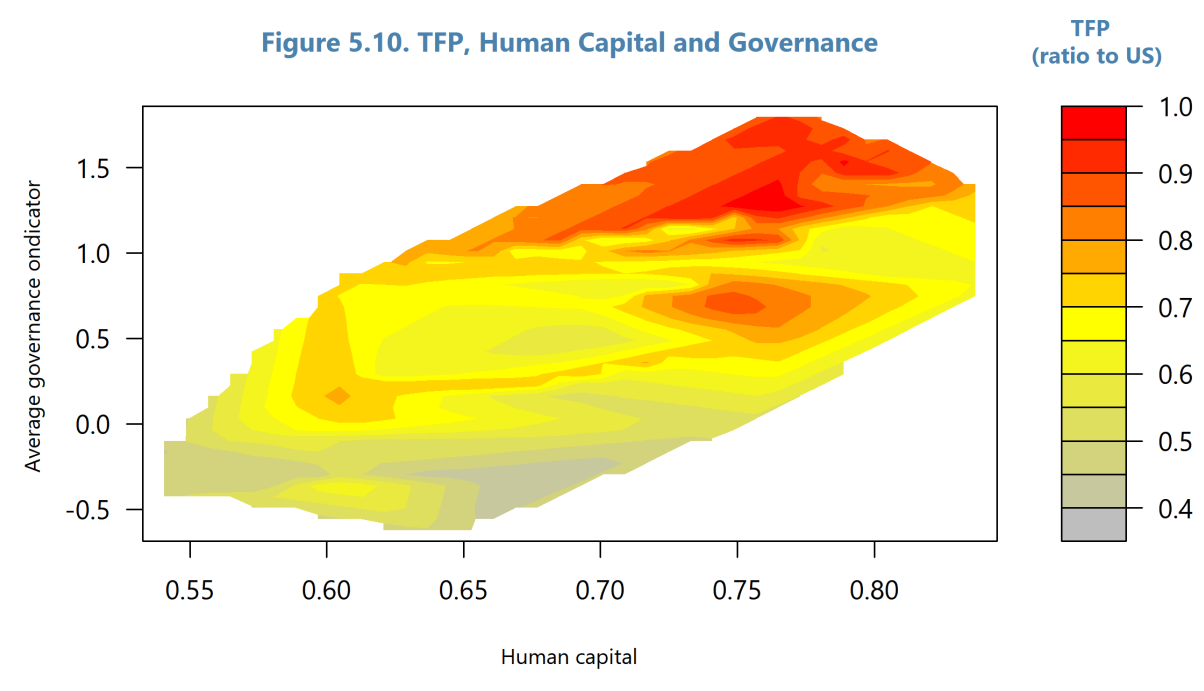

Source: Penn World Tables 9.1 and World Bank.

Includes 46 countries.

Figure 5.11. TFP, Human Capital and Global Competitiveness Indicator $\begin{gathered}\text { TFP } \\ \text { (ratio to US) }\end{gathered}$

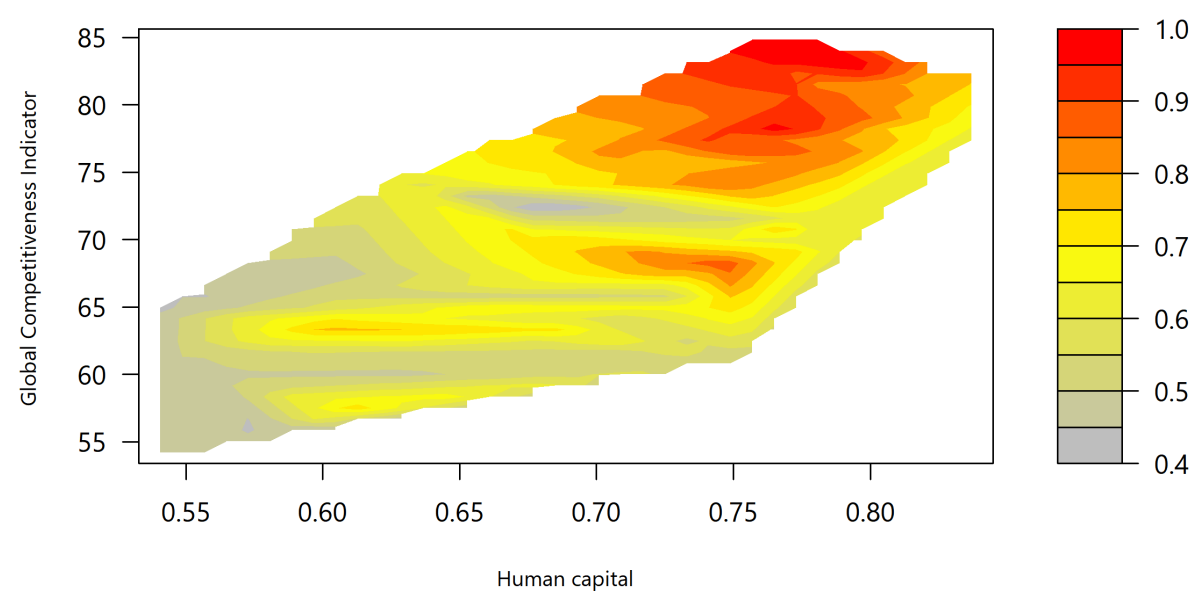

Source: Penn World Tables 9.1 and World Bank

Includes 46 countries. 


\section{What Explains Convergence?}

6 Income Levels, Institutions and Human Capital

If cross-country differences in income are the result of differences in human capital and TFP, and TFP depends on human capital and institutions, we would expect that cross-country differences in income levels are the result of differences in institutions and human capital. We show that this is indeed the case.

\subsection{Indicators of Institutional Strength, Competitiveness, Human Capital and GDP per Capita}

There is a strong link between indicators of institutional strength and GDP per capita levels. Figure 6.1 shows that countries that score better on government effectiveness tend to be richer. The link with the rule of law, control of corruption and regulatory quality is similarly strong (Table 1).

There is a similar association between the World Economic Forum global competitiveness indicators and GDP per capita levels. Figure 6.2 shows the link between the overall indicator and GDP per capita. The link with infrastructure, skills, institutions and innovation capability is also very strong (Table 2 ).

Indicators of human capital have a strong link with GDP per capita (Figure 6.3). The link exists whether we use human capital input or human capital output indicators. 
Figure 6.1. Governance and GDP per Capita, 2017.

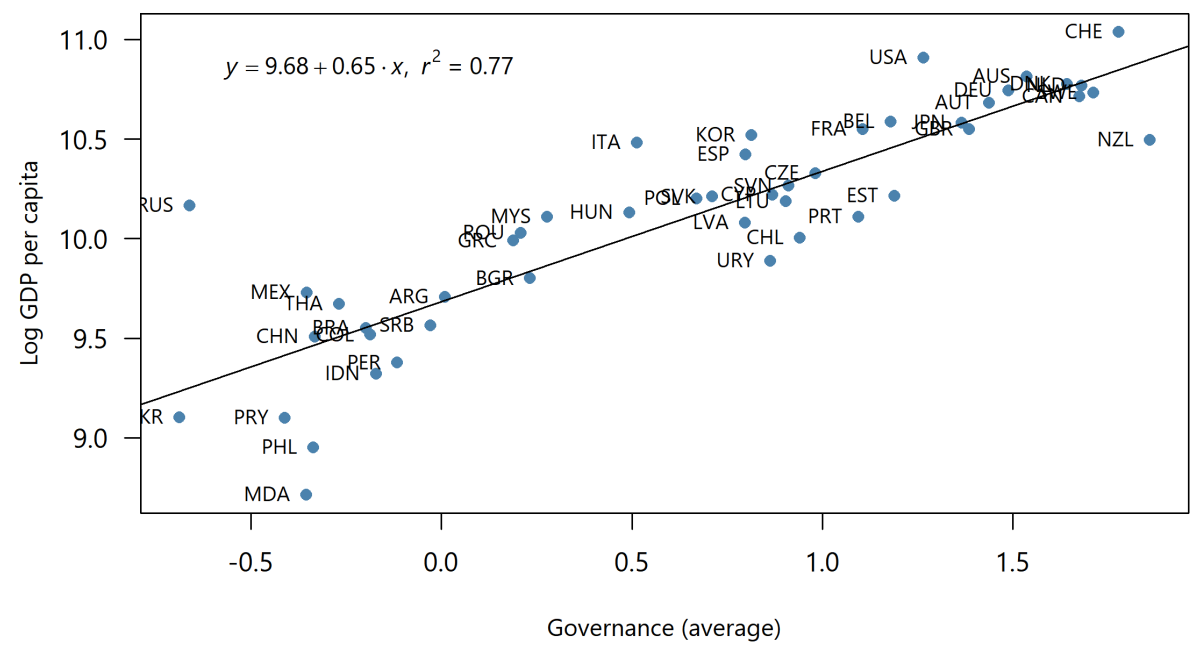

Source: Penn World Tables 9.1 and World bank governance indicators.

Figure 6.2. World Competitiveness Indicator and 2017 GDP per Capita

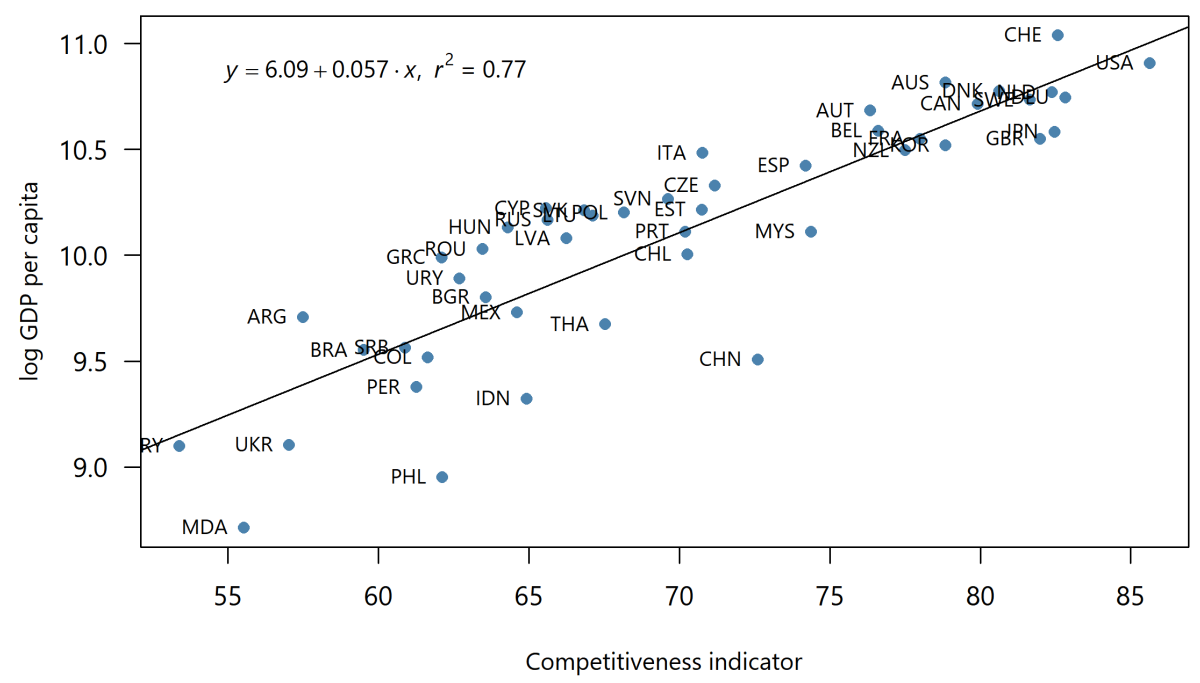

Source: Penn World Tables 9.1 and World competitiveness indicators. 
Table 1: Regression of log GDP per Capita on World Bank Governance Indicators

\begin{tabular}{rrrr}
\hline & Coefficient & t-value & $\mathrm{R} 2$ \\
\hline Rule of Law & 0.60 & 15.37 & 0.85 \\
Government Effectiveness & 0.69 & 15.05 & 0.84 \\
Average & 0.71 & 14.57 & 0.83 \\
Regulatory Quality & 0.69 & 12.29 & 0.78 \\
Control of Corruption & 0.51 & 11.37 & 0.75 \\
Voice and Accountability & 0.62 & 7.78 & 0.58 \\
Political Stability & 0.61 & 7.54 & 0.57 \\
\hline
\end{tabular}

Table 2: Regression of log GDP per Capita on Global Competitiveness Indicators and Subcomponents

\begin{tabular}{rrrr}
\hline & Coefficient & t-value & $\mathrm{R} 2$ \\
\hline Overall & 0.06 & 12.58 & 0.79 \\
Infrastructure & 0.05 & 11.77 & 0.76 \\
Innovation capability & 0.03 & 11.50 & 0.75 \\
Institutions & 0.05 & 11.09 & 0.74 \\
Skills & 0.06 & 10.90 & 0.73 \\
Health & 0.05 & 7.72 & 0.58 \\
Businesss dynamism & 0.05 & 7.37 & 0.56 \\
Product market & 0.06 & 6.91 & 0.53 \\
Financial system & 0.03 & 6.52 & 0.50 \\
Labor market & 0.05 & 6.06 & 0.46 \\
ICT adoption & 0.03 & 5.93 & 0.45 \\
Macro stability & 0.03 & 4.86 & 0.35 \\
Market size & 0.01 & 2.05 & 0.09 \\
\hline
\end{tabular}


Figure 6.3. Human Capital and GDP per Capita, 2017.

Human capital input score vs GDP per capita

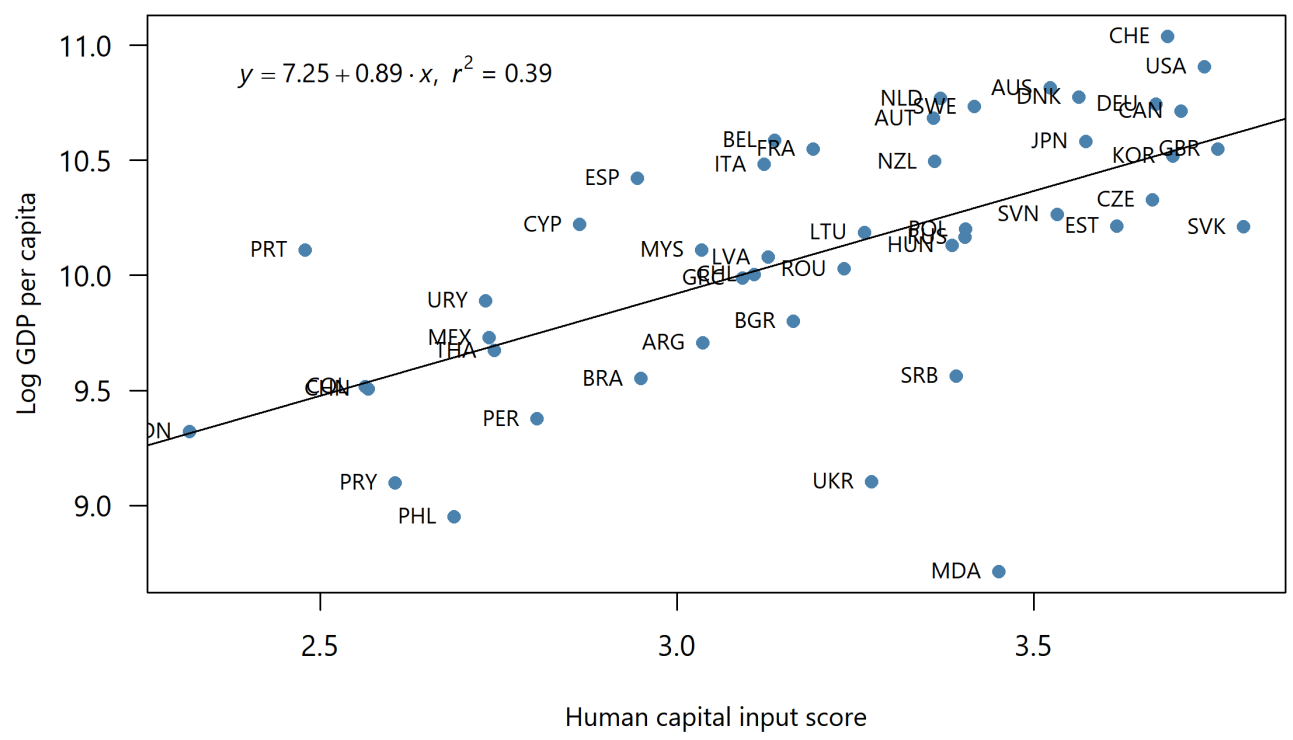

Human capital output score vs GDP per capita

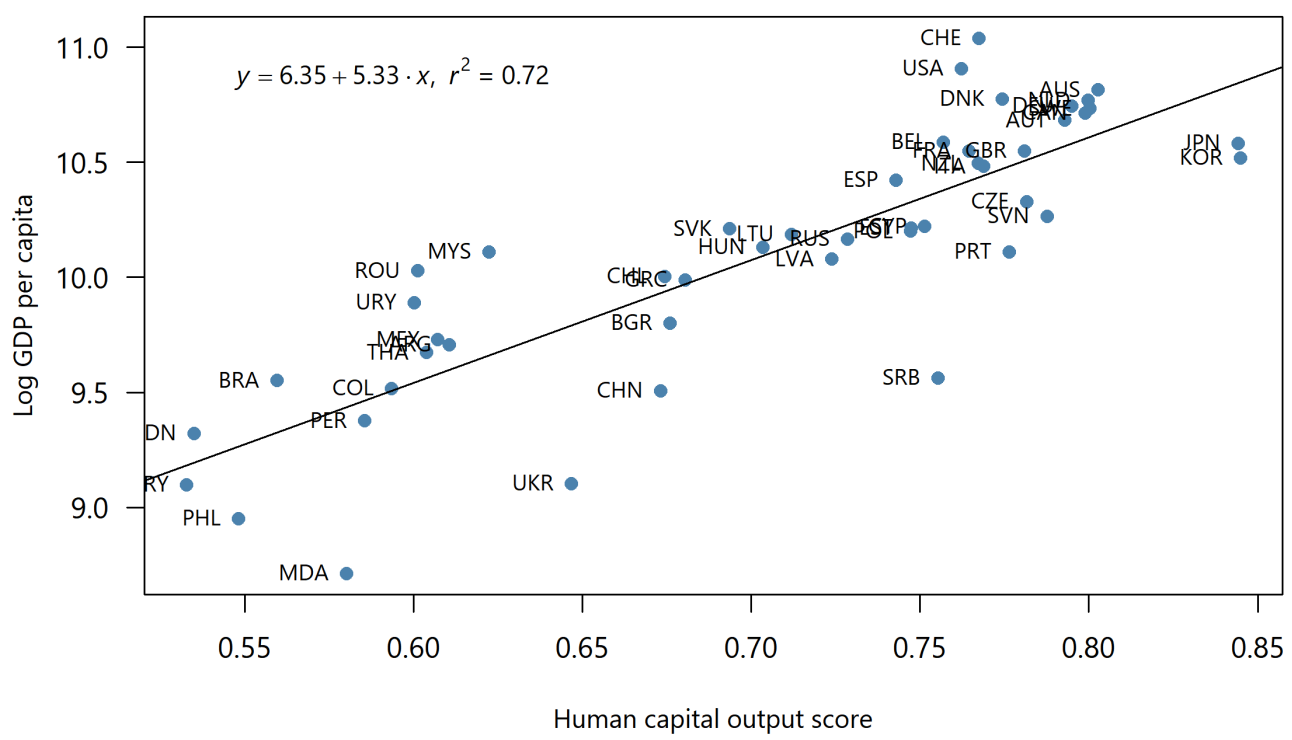

Source: Penn World Tables 9.1 and World Bank 


\subsection{Disentangling the importance of the various factors}

We run regressions to disentangle the role of the various explanatory variables. We regress log GDP per capita in 2017 on governance, competitiveness, human capital input and human capital output (Table 3). All variables are highly significant and the relationships are very strong. In terms of the $R^{2}$, the strongest is with governance, competitiveness followed by human capital output and human capital input. With adding government effectiveness and human capital all variables are still highly significant, and the $R^{2}$ is very high.

Figures 6.4 and 6.5 show that human capital is a necessary but not sufficient condition for high GDP . Rich countries have both high human capital and strong institutions. Countries with high human capital but weak institutions are relatively poor.

Table 3: Regressions of 2017 GDP per Capita Levels

\begin{tabular}{|c|c|c|c|c|c|c|}
\hline & \multicolumn{6}{|c|}{ Log GDP per capita, 2017} \\
\hline & (1) & (2) & (3) & $(4)$ & $(5)$ & (6) \\
\hline Governance & $\begin{array}{c}0.705^{* * *} \\
(0.048)\end{array}$ & & & & $\begin{array}{c}0.516^{* * *} \\
(0.079)\end{array}$ & \\
\hline Competitiveness & & $\begin{array}{c}0.058^{* * *} \\
(0.005)\end{array}$ & & & & $\begin{array}{c}0.038^{* * *} \\
(0.007)\end{array}$ \\
\hline Human capital input & & & $\begin{array}{c}0.914^{* * *} \\
(0.171)\end{array}$ & & & \\
\hline Human capital output & & & & $\begin{array}{c}5.347^{* * *} \\
(0.512)\end{array}$ & $\begin{array}{c}1.876^{* * *} \\
(0.644)\end{array}$ & $\begin{array}{c}2.434^{* * *} \\
(0.641)\end{array}$ \\
\hline Constant & $\begin{array}{c}9.630^{* * *} \\
(0.048)\end{array}$ & $\begin{array}{c}6.009^{* * *} \\
(0.328)\end{array}$ & $\begin{array}{c}7.168^{* * *} \\
(0.554)\end{array}$ & $\begin{array}{c}6.336^{* * *} \\
(0.364)\end{array}$ & $\begin{array}{c}8.435^{* * *} \\
(0.413)\end{array}$ & $\begin{array}{c}5.710^{* * *} \\
(0.297)\end{array}$ \\
\hline$N$ & 45 & 45 & 45 & 45 & 45 & 45 \\
\hline $\mathrm{R}^{2}$ & 0.832 & 0.786 & 0.399 & 0.717 & 0.860 & 0.841 \\
\hline Adjusted $\mathrm{R}^{2}$ & 0.828 & 0.781 & 0.385 & 0.711 & 0.853 & 0.833 \\
\hline
\end{tabular}


Figure 6.4. GDP per Capita, Human Capital and Governance
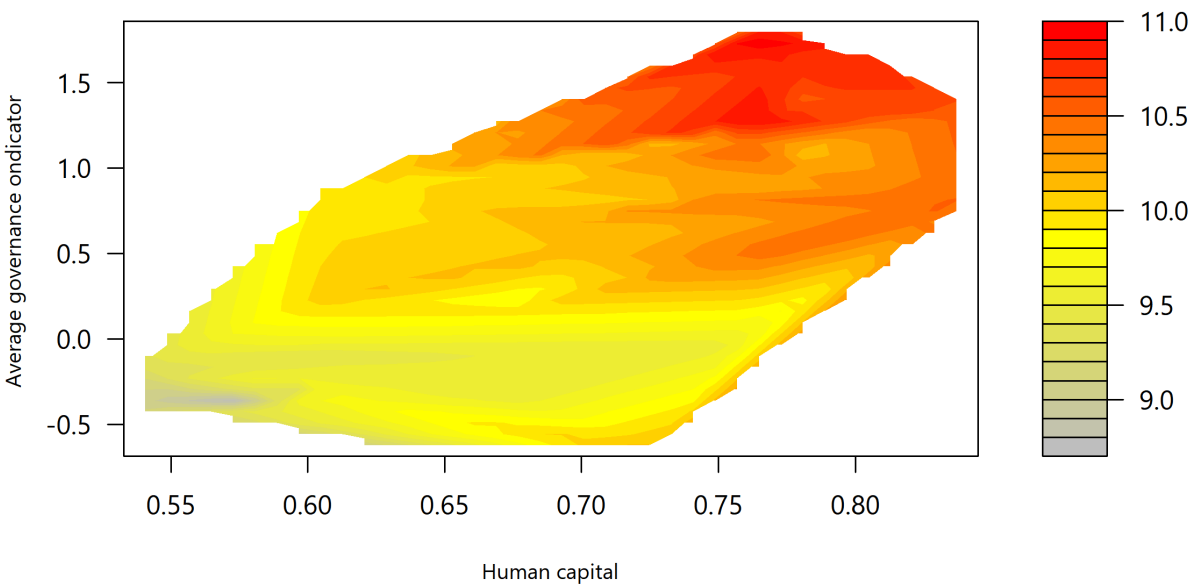

Source: Penn World Tables 9.1, World Bank human capital and governance indicators. Includes all 46 countries.

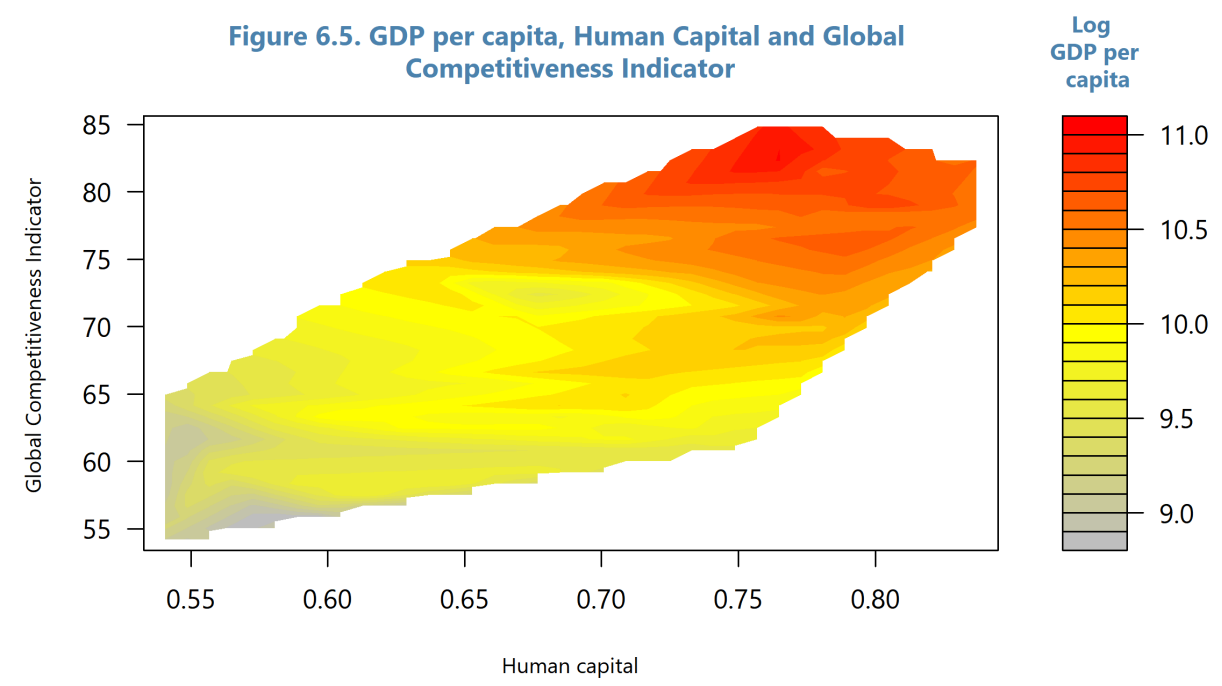

Source: Penn World Tables 9.1, World Bank human capital and global competitive indicators. Includes all 46 countries. 
7 Convergence: The Role of Changes in Fundamentals

If income levels depend on institutions and human capital, then for convergence to occur either (i) institutions and human capital need to improve or (ii) initial income levels start below those suggested by "fundamentals"—i.e., institutions and human capital.

We demonstrate that once levels of human capital and governance are taken into account, there is indeed strong conditional cross-country convergence. Poor countries with high levels of human capital, governance or business climate indicators converge rapidly. Poor countries without those attributes do not.

\subsection{Conditional convergence with Initial Income Levels and Fundamentals}

The discussion so far suggests that GDP growth not only depends on income levels (the poorer the country, the faster it grows), but also on the strength of institutions and human capital. We therefore regress the following equation:

$$
\log Y_{i}^{2017}-\log Y_{i}^{1996}=\pi-\alpha Y_{i}^{1996}+\beta I_{i}^{2017}+\gamma H_{i}^{2017}
$$

where $Y$ stands for GDP per capita, $I$ for institutions (governance or competitiveness), and $H$ for human capital. The results are in Table 4. Column 1 shows the regression of the change in GDP per capita between 1996 and 2017 on GDP per capita in 1996. The coefficient is highly significant. Its value is about 0.3 , suggesting that 30 percent of initial income differences disappeared over the 21-year period. Adding the 2017 level of government effectiveness and human capital significantly raises the fit; it also increases the value of the convergence coefficient. Our preferred specification is in Column 5. This equation shows that once human capital output and governance are taken into account, more than half of the income differentials disappeared during the 1996-2017 period. We also obtain similar results when running the same regression but but replaced governance with competitiveness (Column 6);

We can also link convergence to the strength of institutions and human capital in the starting year:

$$
\log Y_{i}^{2017}-\log Y_{i}^{1996}=\pi-\alpha Y_{i}^{1996}+\beta I_{i}^{1996}+\gamma H_{i}^{1996}
$$

One problem is that the human capital output variable is not available for 1996. We therefore use human capital input. The results are in table 5. Governance is highly significant; human capital input barely.

The regression results in table 4 and 5 confirm our conjecture that both initial income levels and "fundamentals" matter. Conditional convergence is much stronger than unconditional convergence.

This finding is in line with the literature that there is little evidence of unconditional convergence, but there is evidence of conditional convergence. Jones (2016) shows that while 
incomes of OECD countries tend to converge, incomes of a broader group of economies do not. Mankiw et al. (1992) and Barro (1996) argue that countries that share similar sets of characteristics (such as saving rates, population growth rates and TFP), tend to converge to the same income level. 
Table 4: Regressions of Change in GDP per capita, 1996-2017

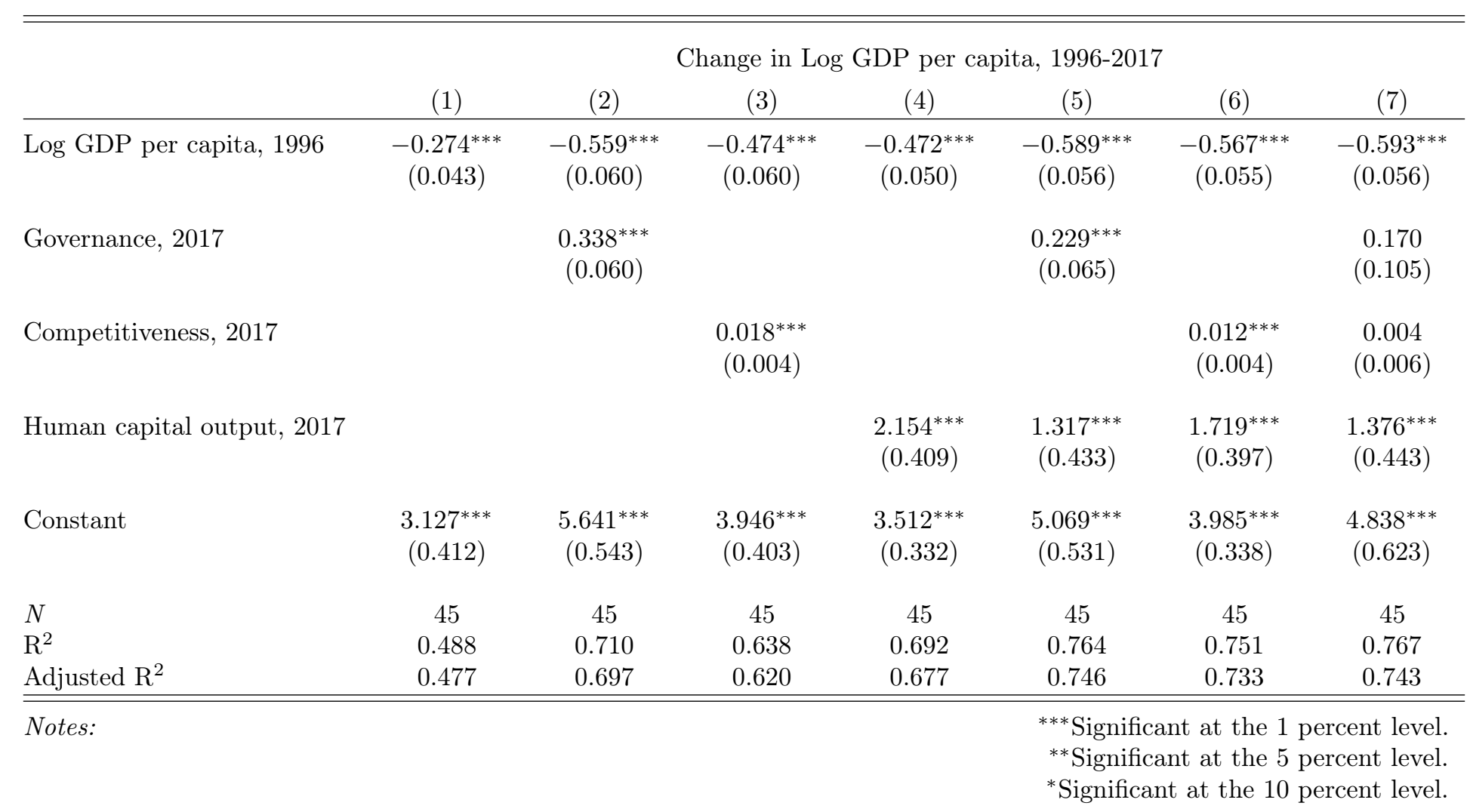


Table 5: Regressions of Change in GDP per capita, 1996-2017

\begin{tabular}{|c|c|c|c|c|}
\hline & \multicolumn{4}{|c|}{ Change in Log GDP per capita, 1996-2017 } \\
\hline & $(1)$ & $(2)$ & $(3)$ & $(4)$ \\
\hline Log GDP per capita, 1996 & $\begin{array}{c}-0.274^{* * *} \\
(0.043)\end{array}$ & $\begin{array}{c}-0.388^{* * *} \\
(0.050)\end{array}$ & $\begin{array}{c}-0.468^{* * *} \\
(0.083)\end{array}$ & $\begin{array}{c}-0.492^{* * *} \\
(0.077)\end{array}$ \\
\hline Governance, 1996 & & $\begin{array}{c}0.282^{* * *} \\
(0.079)\end{array}$ & & $\begin{array}{c}0.233^{* * *} \\
(0.082)\end{array}$ \\
\hline Human capital input, 1996 & & & $\begin{array}{l}0.198^{* *} \\
(0.074)\end{array}$ & $\begin{array}{l}0.126^{*} \\
(0.073)\end{array}$ \\
\hline Constant & $\begin{array}{c}3.127^{* * *} \\
(0.412)\end{array}$ & $\begin{array}{c}3.429^{* * *} \\
(0.375)\end{array}$ & $\begin{array}{c}4.857^{* * *} \\
(0.756)\end{array}$ & $\begin{array}{c}4.481^{* * *} \\
(0.712)\end{array}$ \\
\hline$N$ & 45 & 45 & 45 & 45 \\
\hline $\mathrm{R}^{2}$ & 0.488 & 0.608 & 0.562 & 0.634 \\
\hline Adjusted $\mathrm{R}^{2}$ & 0.477 & 0.589 & 0.541 & 0.608 \\
\hline
\end{tabular}

\subsection{Conditional convergence with Initial Income Gap and Change in Fundamentals}

We will now show that convergence depends on both initial "income gaps" and the change in fundamentals. We determine initial income gaps as the residual in the following regression:

$$
\log Y_{i}^{1996}=\lambda+\theta I_{i}^{1996}+\phi H_{i}^{1996}
$$

If GDP per capita in 1996 is lower than what would be expected given levels of human capital and institutions, the residual will be negative, and we would expect subsequent GDP growth to be relatively rapid. We then use the residual in the following regression:

$$
\log Y_{i}^{2017}-\log Y_{i}^{1996}-\pi-\gamma g a p_{i}+\alpha\left(I_{i}^{2017}-I_{i}^{1996}\right)+\beta\left(H_{i}^{2017}-H_{i}^{1996}\right)
$$

where gap is the income gap, i.e., the residual in equation (19). The results are in Table 6 .

Column 1 shows that the initial income gap matters: the coefficient of the residual is highly significant. Its value is about 0.47 , suggesting that about half of the income gap disappears during the 1996-2017 period.

Our preferred specification is in Column 4. This equation suggests that changes in government effectiveness and human capital matter as well. 
Overall, these results confirm the view that convergence depends on both initial income gaps and the change in fundamentals.

Table 6: Regressions of Change in Log GDP per capita, 1996-2017

\begin{tabular}{|c|c|c|c|c|}
\hline & \multicolumn{4}{|c|}{ Change in Log GDP per capita, 1996-2017 } \\
\hline & $(1)$ & $(2)$ & $(3)$ & $(4)$ \\
\hline Income gap, 1996 & $\begin{array}{c}-0.492^{* * *} \\
(0.100)\end{array}$ & $\begin{array}{c}-0.527^{* * *} \\
(0.073)\end{array}$ & $\begin{array}{c}-0.475^{* * *} \\
(0.096)\end{array}$ & $\begin{array}{c}-0.511^{* * *} \\
(0.068)\end{array}$ \\
\hline Change in governance, 1996-2017 & & $\begin{array}{c}0.532^{* * *} \\
(0.086)\end{array}$ & & $\begin{array}{c}0.518^{* * *} \\
(0.080)\end{array}$ \\
\hline Change in human capital input, 1996-2017 & & & $\begin{array}{l}0.427^{* *} \\
(0.189)\end{array}$ & $\begin{array}{c}0.374^{* * *} \\
(0.135)\end{array}$ \\
\hline Constant & $\begin{array}{c}0.493^{* * *} \\
(0.035)\end{array}$ & $\begin{array}{c}0.491^{* * *} \\
(0.025)\end{array}$ & $\begin{array}{c}0.324^{* * *} \\
(0.081)\end{array}$ & $\begin{array}{c}0.344^{* * *} \\
(0.058)\end{array}$ \\
\hline$N$ & 45 & 45 & 45 & 45 \\
\hline $\mathrm{R}^{2}$ & 0.361 & 0.666 & 0.431 & 0.718 \\
\hline Adjusted $\mathrm{R}^{2}$ & 0.346 & 0.650 & 0.404 & 0.698 \\
\hline
\end{tabular}

Notes:

*** Significant at the 1 percent level. ** Significant at the 5 percent level. *Significant at the 10 percent level. 


\section{Wart III has Latin America not converged like CESEE?}

8 Explaining the differences in convergence between Latin America and
CESEE

We previously discussed that for convergence to occur either (i) institutions and human capital need to improve or (ii) initial income levels start below those suggested by "fundamentals"-i.e., institutions and human capital.

In practice, both factors explain why CESEE has converged and Latin America has not:

- CESEE and East and Southeast Asia have seen an improvement in institutions in the past 25 years, unlike South America and Mexico. Between 1995 an 2017, countries in CESEE and East and Southeast Asia saw an improvement in government effectiveness, rule of law, regulatory quality and control of corruption (Figure 8.1). By contrast, many countries in South America and Mexico saw a deterioration in these indicators. Most countries saw an improvement in human capital. Countries in East and Southeast Asia saw the strongest improvement, but there were also improvements in many countries in CESEE and in South America (Figure 8.2).

- Many countries in CESEE had income levels in the mid-1990s that were below what could expected given their human capital (Figure 8.3). As a result, strong growth ensued. 
Figure 8.1. Changes in Governance Indicators, 1996-2017

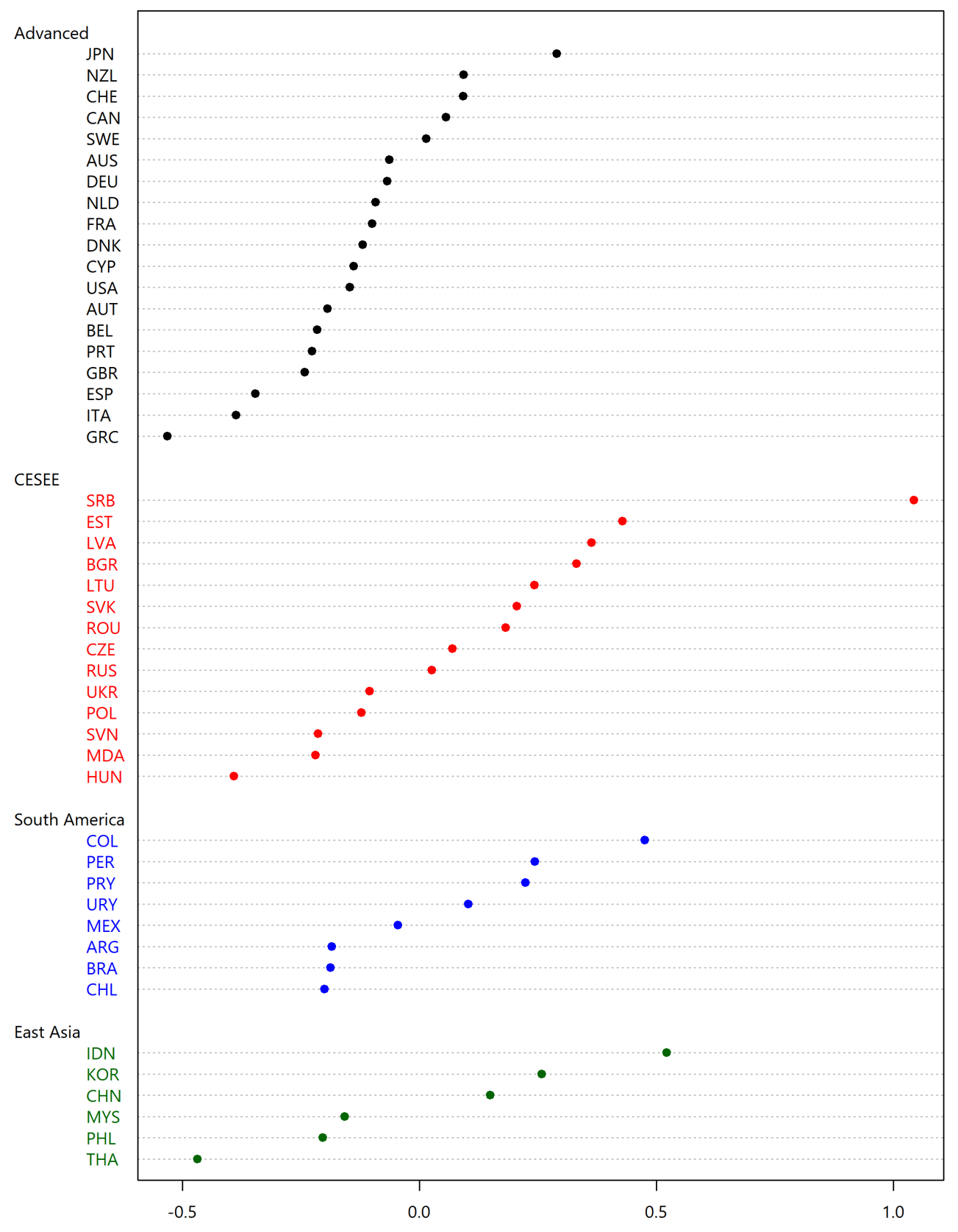

Source: World Bank Governance Indicators 
Figure 8.2. Changes in Human Capital (based on years of schooling), 1995-2017

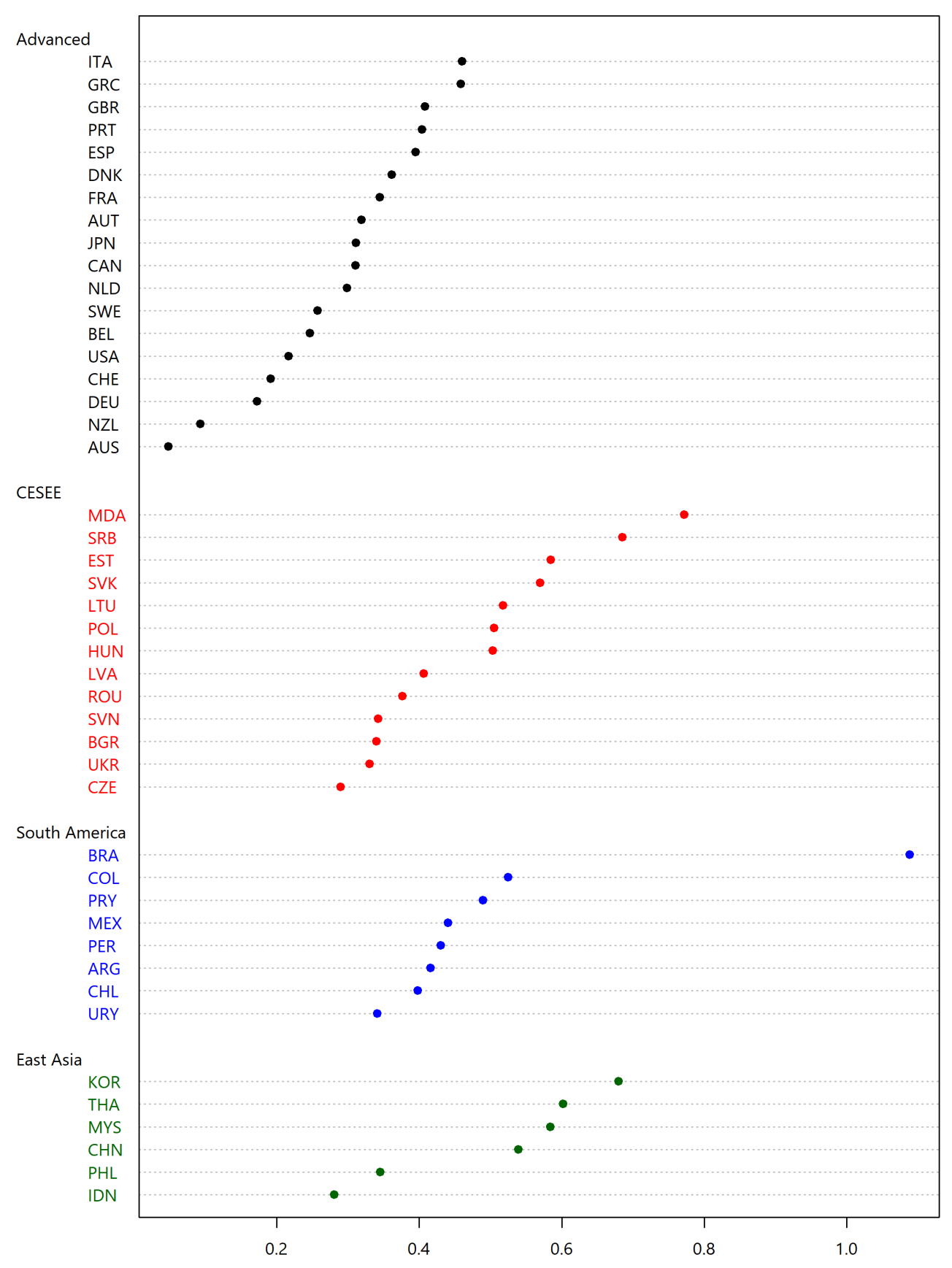

Source: Penn World Tables, 9.1 
Figure 8.3. Income gap in 1996 and GDP per capita growth, 1996-2017

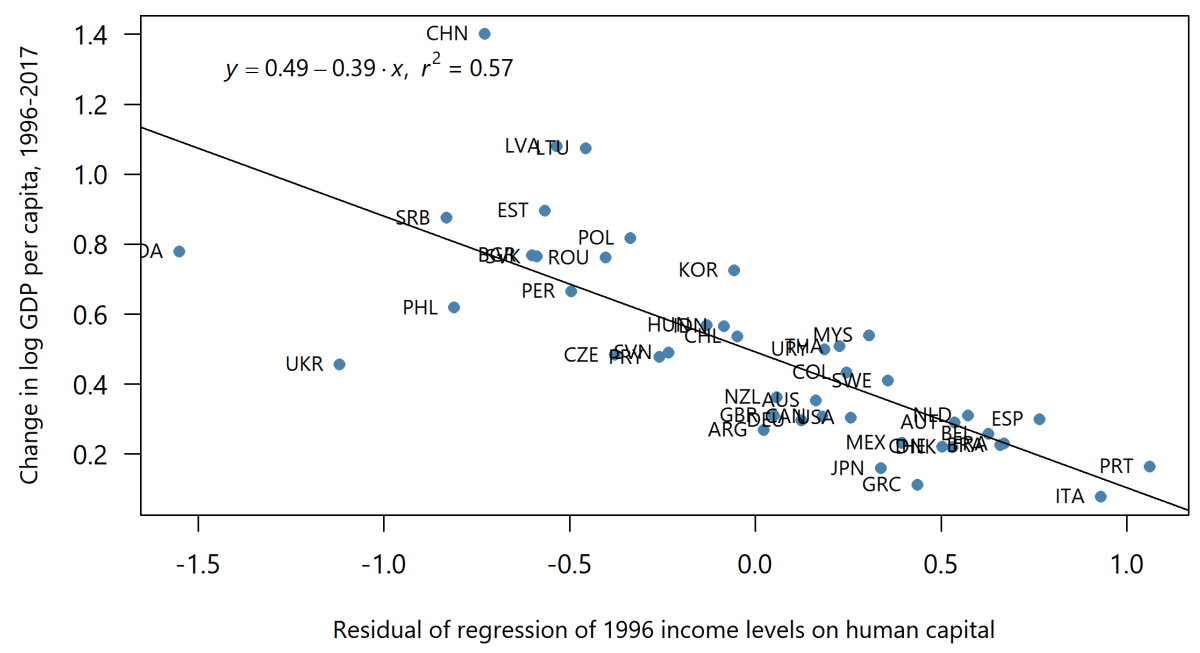

Source: World Bank Governance Indicators 


\subsection{Why has CESEE converged rapidly?}

In the past 25 years there has been rapid convergence of GDP per capita levels in CESEE with those in Western Europe. In 1989, on the eve of the fall of the Berlin wall, CESEE countries were still much poorer than Western Europe. Now, some parts of CESEE now have income levels similar to Spain and Italy. However, not all countries have done equally well. Ukraine and Moldova are still poorer than they were in $1989 .{ }^{14}$

Rapid convergence was associated with rapid and deep reforms. In the early 1990s, there was a debate whether reforms should be gradual. The worry was that more rapid reforms would be too painful. Rapid reforms were indeed painful-unemployment in early reformers rose sharply. However, countries that postponed reforms had a much longer and deeper initial recession, as without a hard budget constraint on firms, it was hard to get credit growth and inflation under control. Poland reformed early and started growing again in 1992 (Figure 8.4), after its economy had shrunk by 15 percent; Ukraine reformed later and partial, and its economy started growing again only in 1999, after GDP had shrunk by two thirds. Weaker growth in early transition was not compensated by faster growth later.

Convergence was most rapid in the EU New Member States. EU accession was a powerful catalyst for reforms and upgrading of institutional frameworks. Prospects of EU membership led to more reforms (Figure 8.5) and higher growth. The result was convergence of institutional strength among EU members and candidates (Figure 8.6), which contributed to convergence of income levels (Alcidi et al., 2018, Próchniaka and Witkowski, 2014a). In the CIS countries, where there were no such prospects, reforms were much slower. In the Western Balkans, which suffered from a 'lost decade' due to the post-Yugoslavian wars, reforms started later as well (Piotr and Li, 2018).

Rapid growth in EU New Member States was largely driven by TFP, which far exceeded that in Western Europe (see Figure 4.6). Capital inflows were large in the pre-crisis boom years (Bakker and Klingen, 2012), but increases of capital-output ratios did not contribute much to growth in most countries.

High levels of human capital significantly contributed to CESEE convergence. CESEE countries inherited high levels of human capital when communism collapsed (Zoega and Phelps, 2019). Indeed, human capital levels in CESEE were not very different from those in Western Europe, but income levels were much lower (Figure 8.7) ${ }^{15}$

Improvements in institutional quality also helped. Masuch and Moshammer (2016) show that institutional quality is an important explanatory variable for cross-country growth differentials across the EU and long-term growth in European economies. Political and economic integration with the EU with phased policy reforms to modernize institutions and

\footnotetext{
${ }^{14}$ In 1989, Poland and Ukraine had similar income levels, now Poland is about 3 times as rich.

${ }^{15}$ Bobetko and Josip (2017) show a strong positive relationship between the level of human capital (proxied by some measure of cognitive skills) and economic growth for CESEE. Kutan and Yigit (2009) found that human capital is the most important domestic source of labor productivity growth and real convergence in CESEE.
} 
greater financial integration that further propelled innovation activity and institutional changes were especially important for convergence of the EU New Member States to the EU (see Grela et al., 2017, IMF, 2015, Schadler et al., 2006). Good governance, economic freedom, as well as business regulations facilitating foreign investment and improving availability of private credit are also important factors for convergence (Dall'Olio Andrea and Federica, 2014, Próchniaka and Witkowski, 2014b). 
Figure 8.4. Poland and Ukraine: Transition
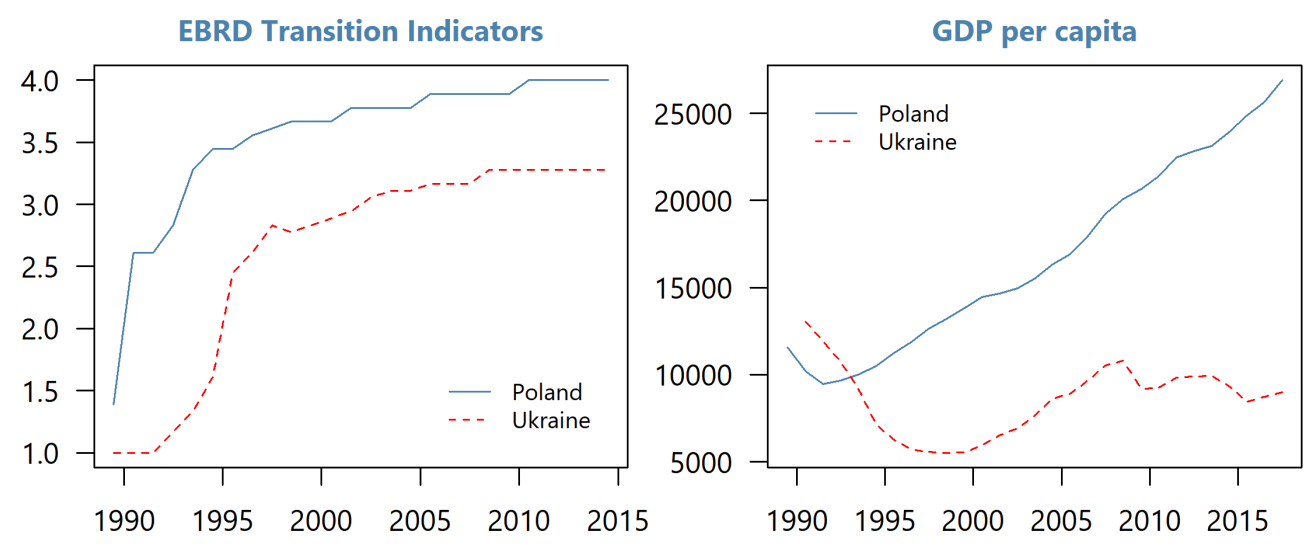

Source: Penn World Tables 9.1 and EBRD Transition Indicators.

Transition indicators measures transition from centrally planned to market economy. Higher scores are better.

Figure 8.5. EBRD Transition Indicators

(Higher is better)
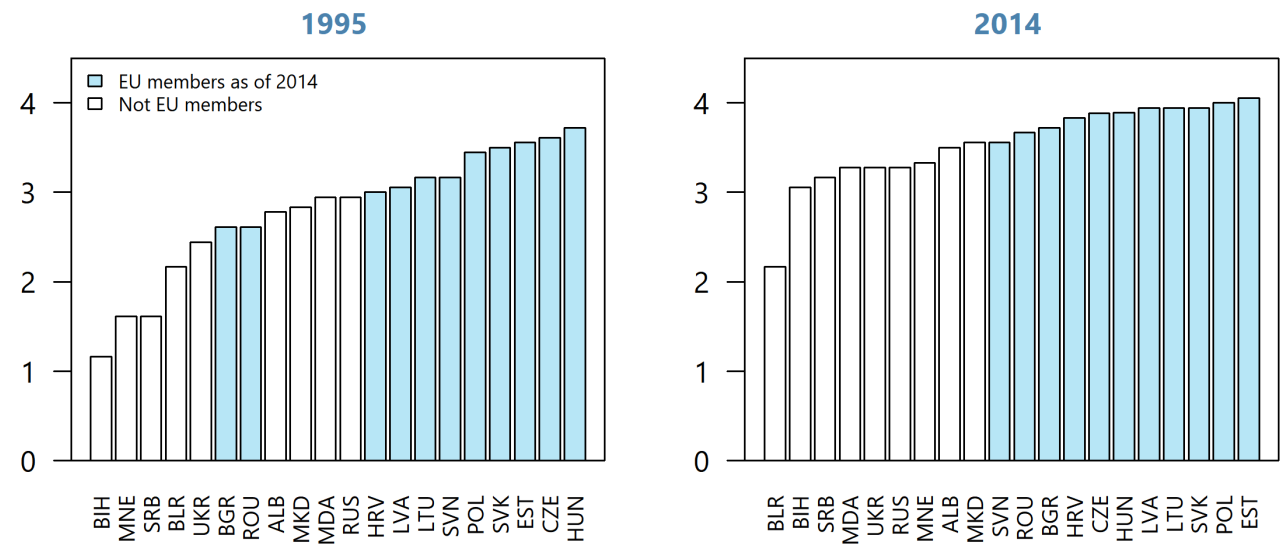

Source: EBRD Transition Indicators

All CESEE EU members joined in 2004, with the exception of Bulgaria and Romania (2007) and Croatia (2013) 
Figure 8.6. Convergence of Government Effectiveness, EU members and Candidate Countries

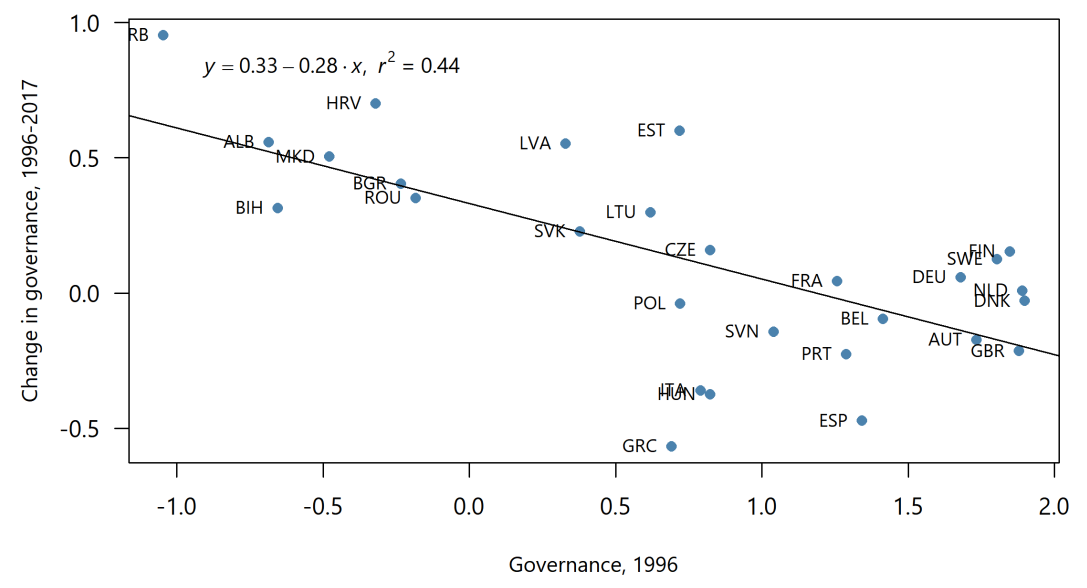

Source: World Bank governance indicators

Average of government effectiveness, rule of law, regulatory quality and control of corruption.

Figure 8.7. Human Capital and GDP per capita, 1996 EU Members and Candidates

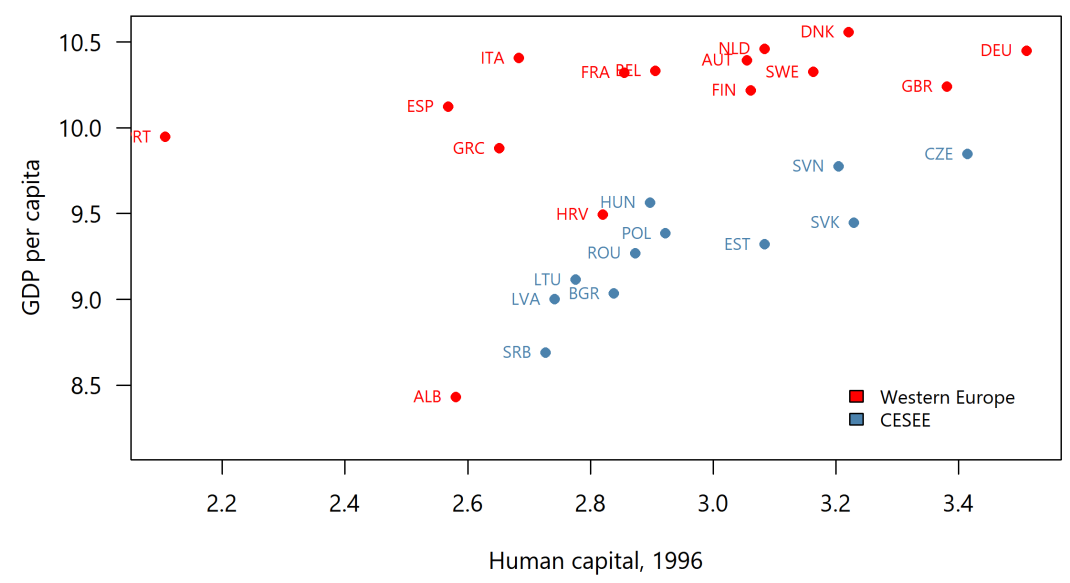

Source: Penn world tables 9.1 


\subsection{Why has Latin America not converged?}

Latin America did not see similar convergence as CESEE because it did not have the large gap between (high) human capital and (low) GDP per capita that CESEE had, and because its institutions did not improve.

- In the mid-1990s, Latin American countries started out with GDP per capita levels that were somewhat above what could be expected given their levels of human capital (Figure 8.8). This was very different from CESEE, where income levels were well below what could be expected.

- Latin America also did not have the strong improvement in institutions that CESEE had. Indeed, there was no convergence of institutional strength with advanced countries (Figure 8.9).

Why did institutions not improve? In the 1980s and early 1990s, many Latin America countries had embarked structural reform, from economic liberalization to political liberalization. Why did reforms not continue?

The economic literature points to reform fatigue. According to Lora et al. (2004), pro-market reform in Latin America countries advanced from the mid-1980s to the mid1990s but showed signs of stall afterward. ${ }^{16}$ They judged that only ten out of twenty Latin America countries continued to make progress in reform in early 2000s while seven countries showed no sign of further reform. Lora et al. (2004) argued that the slow-to-no-progress in reform reflects the reform fatigue. Echoing this, Birdsall et al. (2010) noted that the region entered into a period reform fatigue in 2000s when policy makers in the region found little or no ground to push further additional reforms after many countries had been disappointed by the outcome of the earlier reforms.

Reform fatigue is a result of a mixture of factors. Reviewing the reform experience in Latin America countries in 1990s and 2000s, Powell (2013) noted that a mixture of inappropriate reform measures, poor reform sequencing, and the lack of political viability or institutional capacity linked to incomplete reforms. Incomplete reforms yielded weakerthan-expected growth and increased vulnerability. The experience led to reform fatigue and fall in reform activity subsequently. ${ }^{17}$ Lora et al. (2004) argued that the public's perception that reforms led to weaker growth and higher inequality, despite lack of conclusive evidence, changed the society's attitudes towards pro-market reform negatively and contributed to reform fatigue. 18

\footnotetext{
${ }^{16}$ The extent of pro-market reform in Latin America countries was measured by a composite index constructed in Lora and Panizza (2002).

${ }^{17}$ Birdsall et al. (2010) discussed three widely debated views on why the reform programs in the region did not yield the expected result and often considered ended badly, which includes 1) the implementation of the reform was flawed; 2) the reform program was flawed in itself and 3) the reform program did not include all that was needed.

${ }^{18}$ For example, they found that the attitude of Latin Americans towards pro-market reforms that started
} 
in the 90s had become increasingly critical entering 2000s. According to their study, in 1998, more than 50 percent of Latin Americans thought that privatization was beneficial, but this percentage dropped to 25 percent in 2003. At the same time, the percentage of Latin American thought that a market economy was good for the country dropped from 77 in 1998 to only 18 percent in 2003. Lora and Olivera (2004) found empirically that the incumbent political party would be more likely to loss vote in the next general elections if the government pursued aggressive structural reforms. 
Figure 8.8. Human Capital vs GDP per Capita, 1996

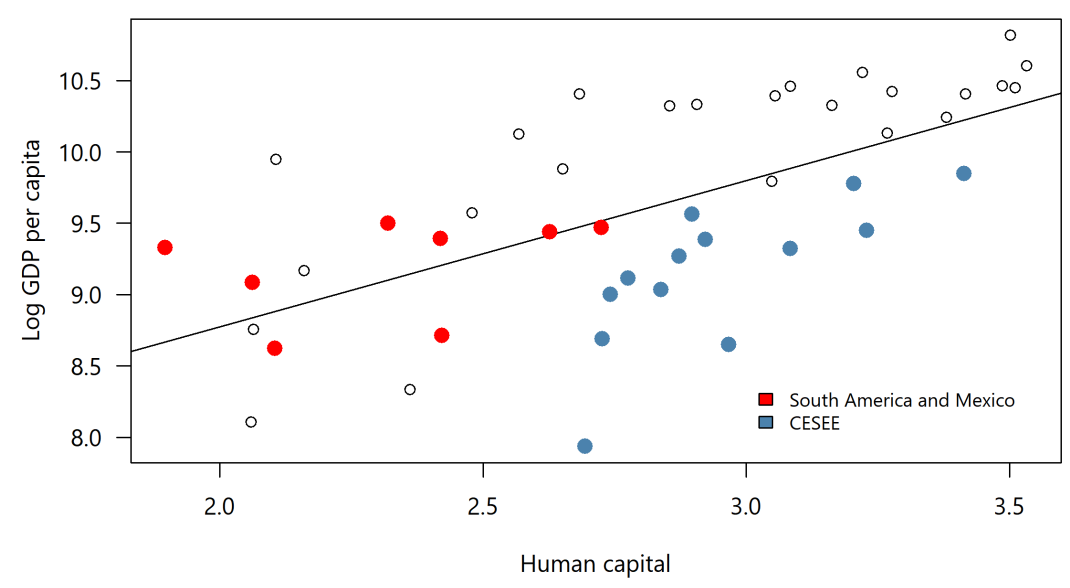

Source: Penn world tables 9.1

Figure 8.9. Convergence of governance, Western Hemisphere

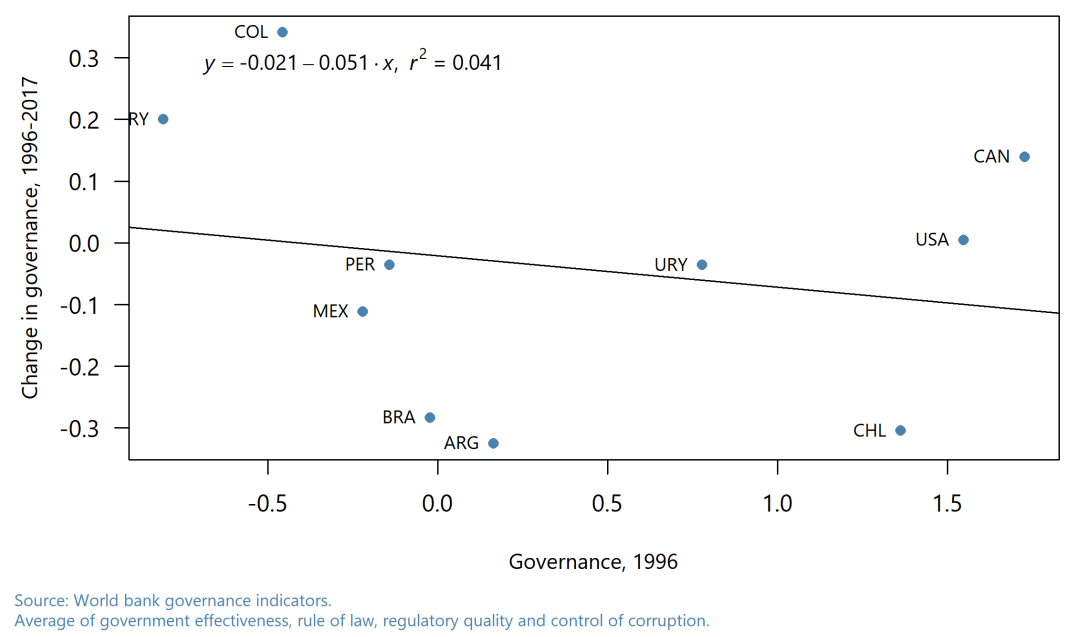

63

CInternational Monetary Fund. Not for Redistribution 
9 Is low investment in Latin America endogenous?

As is well known, there is a strong link between investment and growth. Higher growth is associated with higher investment but could it be the other way around? Blomström et al. (1996) showed that output growth Granger-causes investment. Similarly, Carroll and Weil (1994) showed that causality tends to run from output growth to savings, not the other way around.

Asia has high growth and high investment. Latin America has low growth and low investment. It is tempting to blame low growth on low investment.

Assume that investment is endogenous. The marginal return on $\mathrm{K}$ is the same everywhere.

Then we would expect high investment in countries where $A$ increases rapidly, and low investment in countries where $A$ increases slowly.

\subsection{Why faster TFP and population growth leads to higher investment: Theory}

Production follows a Cobb-Douglas production function: ${ }^{19}$

$$
Y=K^{\alpha \gamma}(A L)^{1-\alpha}
$$

where $A$ is labor-augmenting technological progress, which grows at rate $g$ :

$$
\Delta \log A=g
$$

We assume wages are flexible - labor is fully employed. The labor force is a constant fraction of the population, which grows at rate $n$ :

$$
\Delta \log L=n
$$

Taking logs and differences we can write equation (21) as

$$
y=\alpha \gamma k+(1-\alpha)(n+g)
$$

The capital stock

Firms will expand the capital stock until the marginal product of capital is equal to the cost of capital $\left(r_{c}\right)$ plus depreciation $(\delta)$ :

$$
\max _{K} K^{\alpha \gamma}(A L)^{1-\alpha}-\left(r_{c}+\delta\right) K-w L
$$

It follows that

$$
r_{c}+\delta=\alpha \gamma \frac{Y}{K}
$$

\footnotetext{
${ }^{19}$ This section is based on Bakker (2019).
} 


\section{Steady state}

In the steady state, the capital stock and GDP grow at the same rate, while the investment rate $i$ and $r_{c}$ are constant. It follows from equation (24) that

$$
y=k=\left(\frac{1-\alpha}{1-\alpha \gamma}\right)(n+g)
$$

\section{Investment rate}

The growth rate of the capital stock is equal to:

$$
k=\frac{\dot{K}}{K}=\frac{i Y-\delta K}{K}=\frac{i Y}{K}-\delta
$$

Combining equations (27) and (28) we get:

$$
i=\left(\frac{\alpha \gamma}{r_{c}+\delta}\right)\left(\left(\frac{1-\alpha}{1-\alpha \gamma}\right)(n+g)+\delta\right)
$$

The faster $n+g$, the higher the investment rate. Since we also have $y=\left(\frac{1-\alpha}{1-\alpha \gamma}\right)(n+g)$, we can rewrite equation (29) as

$$
i=\left(\frac{\alpha \gamma}{r_{c}+\delta}\right)(y+\delta)
$$

The faster GDP growth, the higher the investment rate.

\section{Does higher investment lead to higher GDP growth?}

It should be noted that while GDP growth will lead to higher investment rates, the reverse does not hold true. If countries with low $n+g$ have high investment rates, they will end up with high capital-output ratios and high capital consumption to GDP ratios (Bakker, 2019). Japan is a good example of this mechanism. Japan has a gross investment rate of 24 percent of GDP, which is very high given that growth has averaged only [0.5] percent since [2010]. However, capital consumption is 22 percent of GDP, making net investment only 2 percent of GDP, which together with a high capital-output ratio results in low growth. 


\section{Conclusion}

In the past 25 years there has been little convergence of income levels in Latin America with those in the United States. This is sharp contrast with East and Southeast Asia, and Central, Eastern and Southeastern Europe, which have seen rapid convergence.

It has often been argued that the lack of convergence of Latin America is the result of low investment. Investment in Emerging Asia is about [40] percent of GDP, [double] the [20] percent of GDP in Latin America. However, the rapid convergence of Emerging Europe, which has had much more modest investment levels, casts doubt on the narrative that low investment is to blame.

This paper has argued that low investment in Latin America is not the cause but the result of low growth.

- Growth has been low because TFP growth has been low, held back by relatively weak governance and business climate indicators, and by lower levels of human capital. The paper has shown that while unconditional convergence is quite weak, once we take levels of governance, business climate and human capital into account, conditional convergence is strong. Poor countries with high levels of human capital, governance or business climate indicators converge rapidly. Poor countries without those attributes do not.

- Investment has been low because TFP growth has been low. High investment with low TFP growth will lead to a sharp increase in the capital-output ratio and an equivalent drop in the return on capital and net investment (Bakker (2019)). 


\section{Bibliography}

Acemoglu, Daron, Francisco A. Gallego, and James A. Robinson (2014), "Institutions, human capital and development." Annual Review of Economics, 6, 875-912.

Acemoglu, Daron, James Robinson, and Simon Johnson (2005), "Institutions as the fundamental cause of long-run growth." Handbook of Economic Growth, 1A, 386-472.

Aghion, Philippe and Peter Howitt (1992), "A model of growth through creative destruction." Econometrica, 60, 323-351, URL http://www. jstor.org/stable/2951599.

Alcidi, Cinzia, Jorge Ferrer, Roberto Musmeci, Mattia Di Salvo, and Marta Pilati (2018), "Income convergence in the EU: Within-country regional patterns." CEPS, 1-16.

Bakker, Bas B. (2019), "What happens if central banks misdiagnose a slowdown in potential output." IMF Working Paper WP/19/208, International Monetary Fund.

Bakker, Bas B. and Christoph A. Klingen (2012), How emerging Europe came through the 2008/09 Crisis:an account by the staff of the IMF's European Department. International Monetary Fund.

Barro, Robert J (1996), "Determinants of economic growth: A cross-country empirical study." NBER Working Paper 5698, National Bureau of Economic Research, URL http: //www. nber.org/papers/w5698.

Birdsall, Nancy, Augusto de la Torre, and Felipe Valencia Caicedo (2010), "The Washington consensus : assessing a damaged brand." Policy Research Working Paper 5316, The World Bank.

Blomström, Magnus, Robert E. Lipsey, and Mario Zejan (1996), "Is fixed investment the key to economic growth?" The Quarterly Journal of Economics, 111, 269-276, URL http://www.jstor.org/stable/2946665.

Bobetko, Draženović Ivana, Alan and Funda Josip (2017), "Human capital and economic growth in cee countries and other emerging markets." Croatian National Bank, 1-19.

Carroll, Christopher D. and David N. Weil (1994), "Saving and growth: a reinterpretation." Carnegie-Rochester Conference Series on Public Policy, 40, 133-192, URL https:// ideas.repec.org/a/eee/crcspp/v40y1994ip133-192.html.

Comin, Diego (2008), "Total factor productivity." In The New Palgrave Dictionary of Economics (Steven Derlauf and Larry Blume, eds.), second edition, Palgrave Macmillan, Hampshire, U.K.

Dall'Olio Andrea, Kanehira Naoto, Iootty Mariana and Saliola Federica (2014), "Enterprise productivity a three-speed europe." ECB Working paper No 1748, 1-35. 
Easterly, William and Ross Levine (2001), "What have we learned from a decade of empirical research on growth? it's not factor accumulation: Stylized facts and growth models." The World Bank Economic Review, 15, 177-219, URL http://elibrary.worldbank. org/doi/abs/10.1093/wber/15.2.177.

Fadiran, David and Olusegun A. Akanbi (2017), "Institutions and other determinants of total factor productivity in sub-saharan africa." Economic Research Southern Africa (ERSA), 1-29.

Giang, Huong, Xuan Mai, Tran Dang, Bui Huy Trung, Mai Thanh Que, and Yuichiro Yoshida (2018), "Impact of investment climate on total factor productivity of manufacturing firms in vietnam." Sustainability, 10, 1-18.

Grela, Marcin, Aleksandra Majchrowska, Tomasz Michałlek, Jakub Mućk, Agnieszka Stążka-Gawrysiak., Grzegorz Tchorek., and Marcin Wagner (2017), "Is central and eastern europe converging towards the eu-15?" NBP Working Paper No. 264, 1-116.

Grossman, Gene M. and Elhanan Helpman (1991), "Quality ladders in the theory of growth." The Review of Economic Studies, 58, 43-61, URL http://www.jstor.org/ stable/2298044.

Hall, Robert E. and Charles I. Jones (1999), "Why do some countries produce so much more output per worker than others." The Quarterly Journal of Economics, 114, 83-116.

Hanushek, Eric A. and Ludger Woessmann (2012), "Do better schools lead to more growth? cognitive skills, economic outcomes, and causation." Journal of Economic Growth, 17, 267-321, URL https://doi.org/10.1007/s10887-012-9081-x.

Hulten, Charles and Anders Isaksson (2007), "Why development levels differ: The sources of differential economic growth in a panel of high and low income countries." NBER Working Paper Number 13469, National Bureau of Economic Research.

IMF (2015), "Central and eastern europe: New member states (nms) policy forum, 2014." Staff Report on Cluster Consultations - Common Policy Frameworks and Challenges, Country Report, 15/97., 1-40.

Inklaar, Robert, Pieter Woltjer, and Daniel Gallardo Albarrán (2019), "The Composition of Capital and Cross-Country Productivity Comparisons." International Productivity Monitor, 36, 34-52, URL https://ideas.repec.org/a/sls/ipmsls/v36y20192.html.

Joilson, Dias and Tebaldi Edinaldo (2012), "Institutions, human capital, and growth: The institutional mechanism." Structural Change and Economic Dynamics, 23, 300-312.

Jones, Charles. I. (2016), "Chapter 1 - the facts of economic growth." In Handbook of Macroeconomics (John B. Taylor and Harald Uhlig, eds.), volume 2, 3 - 69, Elsevier, URL http://www.sciencedirect.com/science/article/pii/S1574004816000033. 
Kim, Young Eun and Norman Loayza (2017), "Productivity and its determinants: Innovation, education, efficiency, infrastructure, and institutions.", URL http://pubdocs.worldbank.org/en/378031511165998244/ Productivity-and-its-determinants-25-October-2017.pdf. Unpublished Background Paper.

Klenow, Peter J. and Andrés Rodríguez-Clare (1997), "Economic growth: A review essay." Journal of Monetary Economics, 40, 597 - 617, URL http://www.sciencedirect.com/ science/article/pii/S0304393297000500.

Kutan, Ali and Taner Yigit (2009), "European integration, productivity growth and real convergence: Evidence from the new member states." Economic Systems, 33, 127-137.

Lora, Eduardo and Mauricio Olivera (2004), "What makes reforms likely: Political economy determinants of reforms in latin america." Journal of Applied Economics, 7, 99-135, URL https://EconPapers.repec.org/RePEc:cem: jaecon:v:7:y:2004:n:1:p:99-135.

Lora, Eduardo and Ugo Panizza (2002), "Structural reforms in latin america under scrutiny." IDB Working Paper No. 394, Inter-American Development Bank.

Lora, Eduardo, Ugo Panizza, and Myriam Quispe-Agnoli (2004), "Reform fatigue: symptoms, reasons, and implications." Federal Reserve Bank of Kansas City Economic Review, 1-28, URL https://ideas.repec.org/a/fip/fedaer/y2004iq2p1-28nv.89no. 2.html.

Mankiw, N. Gregory, David Romer, and David N. Weil (1992), "A contribution to the empirics of economic growth." The Quarterly Journal of Economics, 107, 407-437, URL https://doi.org/10.2307/2118477.

Masuch, Klaus and Edmund Moshammer (2016), "Institutions and growth in europe." CEPS Working Document No. 421, 1-116.

Nelson, Richard R. and Edmund S. Phelps (1966), "Investment in humans, technological diffusion, and economic growth." The American Economic Review, 56, 69-75, URL http: //www. jstor.org/stable/1821269.

Nguyen, Ha and Patricio Jamarillo (2014), "Institutions and firms' return to innovation: Evidence from the world bank enterprise survey." Policy Research Working Paper Number 6918, The World Bank.

North, Douglass (1990), Institutions, Institutional Change and Economic Performance. Cambridge University Press.

Piotr, Żuk and Savelin Li (2018), "Real convergence in central, eastern and southeastern europe." ECB Occasional Paper, 1-57. 
Powell, Andrew (2013), "2013 latin american and caribbean macroeconomic report: Rethinking reforms: How latin america and the caribbean can escape suppressed world growth." Technical report, The Inter-American Development Bank, URL https://publications.iadb.org/en/publication/10800/ 2013-latin-american-and-caribbean-macroeconomic-report-rethinking-reforms-how.

Próchniaka, Mariusz and Bartosz Witkowski (2014a), "On the stability of the catching-up process among old and new eu member states." Eastern European Economics, 52, 2, $5-27$.

Próchniaka, Mariusz and Bartosz Witkowski (2014b), "Alternative weighting schemes in spatial analysis of gdp per capita convergence." Qualitative Methods in Economics, XV(2), 198-208.

Restuccia, Diego and Richard Rogerson (2013), "Misallocation and productivity." Review of Economic Dynamics, 16, 1 - 10, URL http://www.sciencedirect.com/science/ article/pii/S1094202512000725. Special issue: Misallocation and Productivity.

Romer, David (1993), "Do students go to class? should they?" Journal of Economic Perspectives, 7, 167-174, URL http://www.aeaweb.org/articles?id=10.1257/jep.7.3. 167.

Romer, David (2019), Advanced macroeconomics, 5th edition. McGraw-Hill Publishing, URL http://highered.mheducation.com/sites/1260185214/ information $\left\{\right.$ $_{-}$center $\left\{\_\right.$\}view0/index.html.

Romer, Paul M. (1986), "Increasing returns and long-run growth." Journal of Political Economy, 94, 1002-1037, URL http://www.jstor.org/stable/1833190.

Romer, Paul M. (1990), "Endogenous technological change." Journal of Political Economy, 98, S71-S102, URL https://doi.org/10.1086/261725.

Schadler, Susan, Ashoka Mody, Abdul Abiad, and Daniel Leigh (2006), "Growth in the central and eastern european countries of the european union." IMF Occasional paper 252, 1-12.

Stokey, Nancy L. (1988), "Learning by doing and the introduction of new goods." Journal of Political Economy, 96, 701-717, URL http://www.jstor.org/stable/1830470.

Tebaldia, Edinaldo and Bruce Elmslieb (2013), "Does institutional quality impact innovation? evidence from cross-country patent grant data." Applied Economics, 45:7, 887-900.

Veeramani, C. and Goldar Bishwanath (2004), "Manufacturing productivity in indian states: Does investment climate matter?" Economic and political weekly, 40, 2413-2420. 
Young, Alwyn (1991), "Learning by doing and the dynamic effects of international trade." The Quarterly Journal of Economics, 106, 369-405, URL http://www.jstor.org/ stable/2937942.

Young, Alwyn (1995), "The tyranny of numbers: Confronting the statistical realities of the east asian growth experience." The Quarterly Journal of Economics, 110, 641-680, URL http://www. jstor.org/stable/2946695.

Zoega, Gylfi and Edmund Phelps (2019), "Values, institutions and the rise of eastern europe." Economics of Transition and Institutional Change, 27.1, 247-265. 
A Countries included

In this paper, we compare countries in South America and Mexico with those in Central, Eastern and Southeastern Europe, emerging East and Southeast Asia, and advanced countries. We exclude OPEC countries and other major oil exporters, small countries and city states. We also drop countries for which some of the data used in the paper are not available. This leaves us with a group of 47 countries (Table 6).

Table 7: Countries included

\begin{tabular}{llll}
\hline & & & \\
Advanced & South America and Mexico & CESEE & East and Southeast Asia \\
& & & \\
Cyprus & Argentina & & \\
Greece & Brazil & Bulgaria & China \\
Austria & Chile & Czechia & Indonesia \\
Belgium & Colombia & Estonia & Korea \\
Denmark & Mexico & Hungary & Malaysia \\
France & Peru & Latvia & Philippines \\
Germany & Uruguay & Lithuania & Thailand \\
Italy & Paraguay & Moldova & \\
Netherlands & & Poland & \\
Portgual & & Romania & \\
Spain & & Russia & \\
Sweden & & Serbia & \\
Switzerland & & Slovakia & \\
Great Britain & & Slovenia & \\
United States & & Ukraine & \\
Canada & & \\
Japan & & & \\
New Zealand & & & \\
Australia & & & \\
& & & \\
\hline
\end{tabular}


B Data Sources

- Penn World Tables (PWT) - PWT version 9.1 is a database with information on relative levels of income, output, input and productivity, covering 182 countries between 1950 and 2017.

- The Conference Board Total Economy Database ${ }^{T M}$, April 2019 release - A comprehensive database with annual data covering GDP, population, employment, hours, labor quality, capital services, labor productivity, and Total Factor Productivity for 123 countries in the world. ${ }^{20}$

- The Worldwide Governance Indicators (WGI), 2019 Update - A project reports aggregate and individual governance indicators for over 200 countries and territories over the period 1996-2018, for six dimensions of governance. These aggregate indicators combine the views of a large number of enterprises, citizens and expert survey respondents in industrial and developing countries. They are based on over 30 individual data sources produced by a variety of survey institutes, think tanks, non-governmental organizations, international organizations, and private sector firms.

- The Global Competitiveness Index (GCI) 4.0, Dataset Version 20181013 - The GCI analyze competitiveness along 12 pillars: institutions, infrastructure, macroeconomic environment, health and primary education, higher education and training, goods market efficiency, labour market efficiency,financial market development, technological readiness, market size, business sophistication and innovation. These are, in turn, organized into three subindices in line with three main stages of development: basic requirements, efficiency enhancers, and innovation and sophistication factors. The three subindices are given different weights in the calculation of the overall index, depending on each economy's stage of development, as proxied by its GDP per capita and share of exports represented by mineral raw materials. The index maps the competitiveness landscape of 141 economies through 103 indicators organized into 12 themes. Each indicator, using a scale from 0 to 100, shows how close an economy is to the ideal state or "frontier" of competitiveness.

- World Bank Human Capital Index. The index measures human capital, looking at both health and education. The Index is grounded on three pillars: Survival (share of children surviving past the age of 5 in percent); School, which includes both quantity of education (expected years of schooling by age 18) and quality of education (harmonized test scores); and health (which includes both adult survival rates (share of 15-year-olds who survive until age 60 in percent) and healthy growth among children (stunting rates of children under 5 in percent.)

\footnotetext{
${ }^{20}$ Chinese data is presented in two series, 'China (Alternative)' and 'China (Official)'. The latter is based on official data, while 'China (Alternative)' is from Wu (2014), revised and updated in 2018.
} 
Table 8: Data Sources and Description

\begin{tabular}{|c|c|c|c|c|}
\hline Figure & Variable & Source & Code & Description \\
\hline 1.1 & GDP per capita & WEO & ppppc & $\begin{array}{l}\text { Purchasing Power Parity per capita (PPP } \\
\text { dollars, Units) }\end{array}$ \\
\hline 1.2 & $\begin{array}{l}\text { Investment to } \\
\text { GDP ratio }\end{array}$ & WEO & nid_gdp & $\begin{array}{l}\text { Gross capital formation, current prices in } \\
\text { U.S. dollars, percent of GDP in dollars }\end{array}$ \\
\hline \multirow[t]{4}{*}{1.3} & $\begin{array}{l}\text { Investment to } \\
\text { GDP ratio }\end{array}$ & WEO & nid_gdp & $\begin{array}{l}\text { Gross capital formation, current prices in } \\
\text { U.S. dollars, percent of GDP in dollars }\end{array}$ \\
\hline & Real GDP & WEO & ngdp_r & $\begin{array}{l}\text { Gross domestic product, constant prices } \\
\text { (National Currency, Billions) }\end{array}$ \\
\hline & Population & WEO & lp & Population (Persons, Millions) \\
\hline & GDP per capita & $\begin{array}{l}\text { Staff } \\
\text { Calculations }\end{array}$ & ngdp_r/lp & \\
\hline \multirow[t]{3}{*}{1.4} & $\mathrm{Y}$ & PWT 9.1 & rgdpna & $\begin{array}{l}\text { Real GDP at constant } 2011 \text { national prices } \\
\text { (in mil. 2011US\$) }\end{array}$ \\
\hline & $\mathrm{K}$ & PWT 9.1 & rnna & $\begin{array}{l}\text { Capital Stock at constant } 2011 \text { national } \\
\text { prices (in mil. } 2011 \text { US\$) }\end{array}$ \\
\hline & $\begin{array}{l}\text { Capital-output } \\
\text { ratio }\end{array}$ & $\begin{array}{l}\text { Staff } \\
\text { calculation }\end{array}$ & $\mathrm{K} / \mathrm{Y}$ & \\
\hline \multirow[t]{7}{*}{1.5} & $\begin{array}{l}\text { Real return on } \\
\text { capital }\end{array}$ & PWT 9.1 & irr & Real internal rate of return \\
\hline & & PWT 9.1 & labsh & $\begin{array}{l}\text { Share of labor compensation in GDP at } \\
\text { current national prices }\end{array}$ \\
\hline & $\mathrm{Y}$ & PWT 9.1 & rgdpna & $\begin{array}{l}\text { Real GDP at constant } 2011 \text { national prices } \\
\text { (in mil. 2011US\$) }\end{array}$ \\
\hline & $\mathrm{tfp}$ & PWT 9.1 & rtfpna & TFP at constant national prices $(2011=1)$ \\
\hline & $\mathrm{K}$ & PWT 9.1 & rnna & $\begin{array}{l}\text { Capital stock at constant } 2011 \text { nationa } \\
\text { prices (in mil. } 2011 \text { US\$) }\end{array}$ \\
\hline & $\mathrm{P}$ & PWT 9.1 & pop & Population (in millions) \\
\hline & GDP per capita & $\begin{array}{l}\text { Staff } \\
\text { Calculation }\end{array}$ & $\mathrm{Y} / \mathrm{P}$ & \\
\hline
\end{tabular}




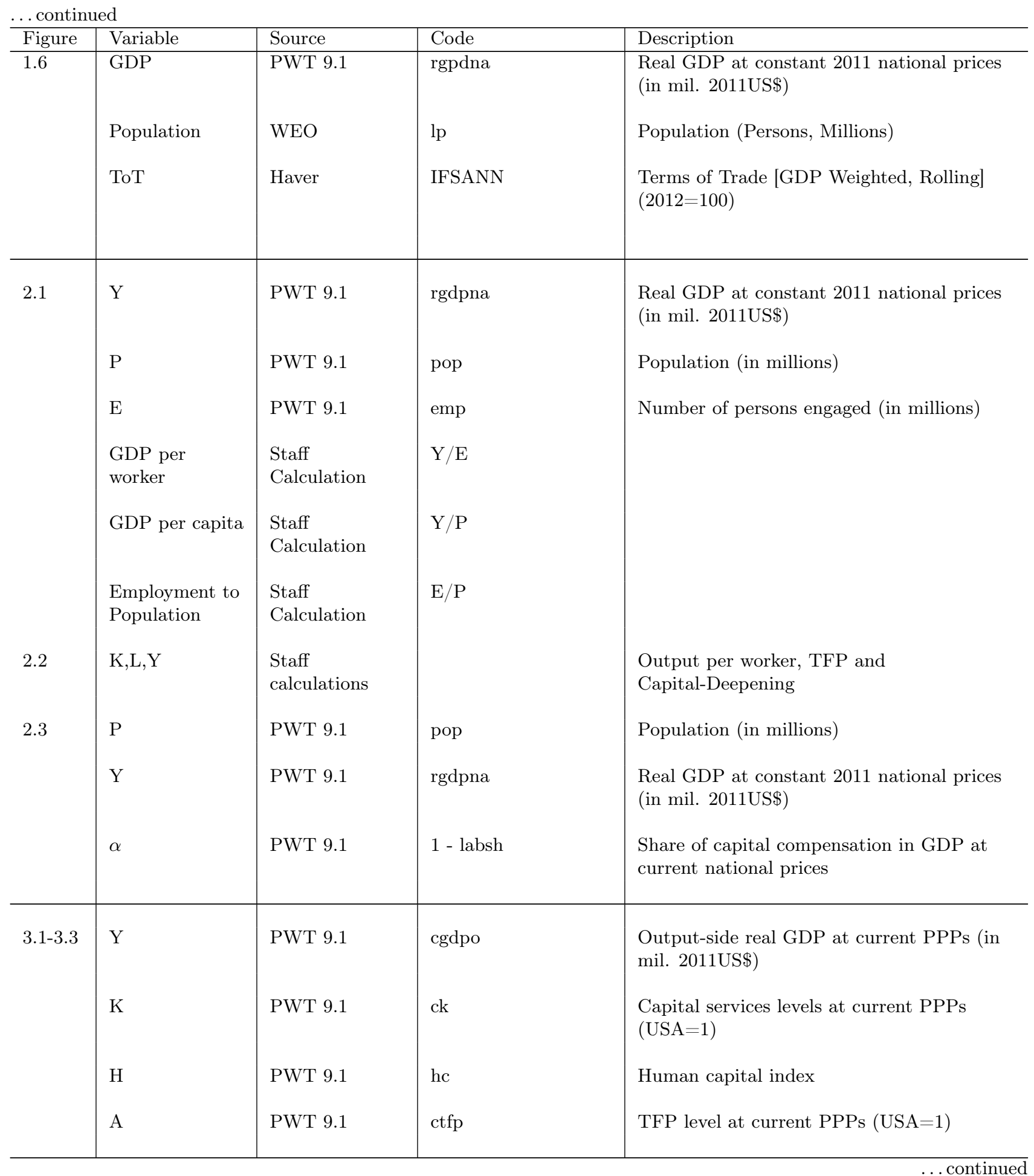




\begin{tabular}{|c|c|c|c|c|}
\hline \multirow[t]{8}{*}{ Figure } & Variable & Source & Code & Description \\
\hline & $\mathrm{L}$ & $\begin{array}{l}\text { Staff } \\
\text { calculations }\end{array}$ & $\mathrm{avh}^{*} \mathrm{emp}$ & \\
\hline & $\mathrm{E}$ & PWT 9.1 & emp & Number of persons engaged (in millions) \\
\hline & & PWT 9.1 & avh & $\begin{array}{l}\text { Average annual hours worked by persons } \\
\text { engaged (source: The Conference Board) }\end{array}$ \\
\hline & $\mathrm{P}$ & PWT 9.1 & pop & Population (in millions) \\
\hline & & PWT 9.1 & labsh & $\begin{array}{l}\text { Share of labour compensation in GDP at } \\
\text { current national prices }\end{array}$ \\
\hline & $\alpha$ & $\begin{array}{l}\text { Staff } \\
\text { calculation }\end{array}$ & 1-labsh & \\
\hline & $\begin{array}{l}\text { Real return on } \\
\text { capital }\end{array}$ & PWT 9.1 & irr & Real internal rate of return \\
\hline \multirow[t]{9}{*}{ 4.1-4.6 } & $\mathrm{y}$ & PWT 9.1 & GDP_g & Growth of GDP, change in the natural log \\
\hline & $\mathrm{k}$ & PWT 9.1 & KSERV_g & $\begin{array}{l}\text { Growth of Total Capital Services, change in } \\
\text { the natural log }\end{array}$ \\
\hline & 1 & PWT 9.1 & Labor_g & $\begin{array}{l}\text { Growth of Labor Quantity, change in the } \\
\text { natural log (in hours) }\end{array}$ \\
\hline & $\mathrm{h}$ & PWT 9.1 & LQ_g & $\begin{array}{l}\text { Growth of Labor Quality, change in the } \\
\text { natural log }\end{array}$ \\
\hline & g & PWT 9.1e & TFP_g & Growth of Total Factor Productivity \\
\hline & $\mathrm{p}$ & PWT 9.1 & & $\begin{array}{l}\text { Growth of population, change in the natural } \\
\text { log }\end{array}$ \\
\hline & & PWT 9.1 & POP & Midyear population (thousands) \\
\hline & & PWT 9.1 & LSH & Share of Total Labor Compensation in GDP \\
\hline & $\alpha$ & $\begin{array}{l}\text { Staff } \\
\text { calculations }\end{array}$ & 1-LSH & \\
\hline \multirow[t]{2}{*}{4.7} & $\mathrm{tfp}$ & PWT 9.1 & rtfpna & TFP at constant national prices $(2011=1)$ \\
\hline & $\mathrm{K}$ & PWT 9.1 & rnna & $\begin{array}{l}\text { Capital Stock at constant } 2011 \text { national } \\
\text { prices (in mil. } 2011 \text { US\$) }\end{array}$ \\
\hline
\end{tabular}




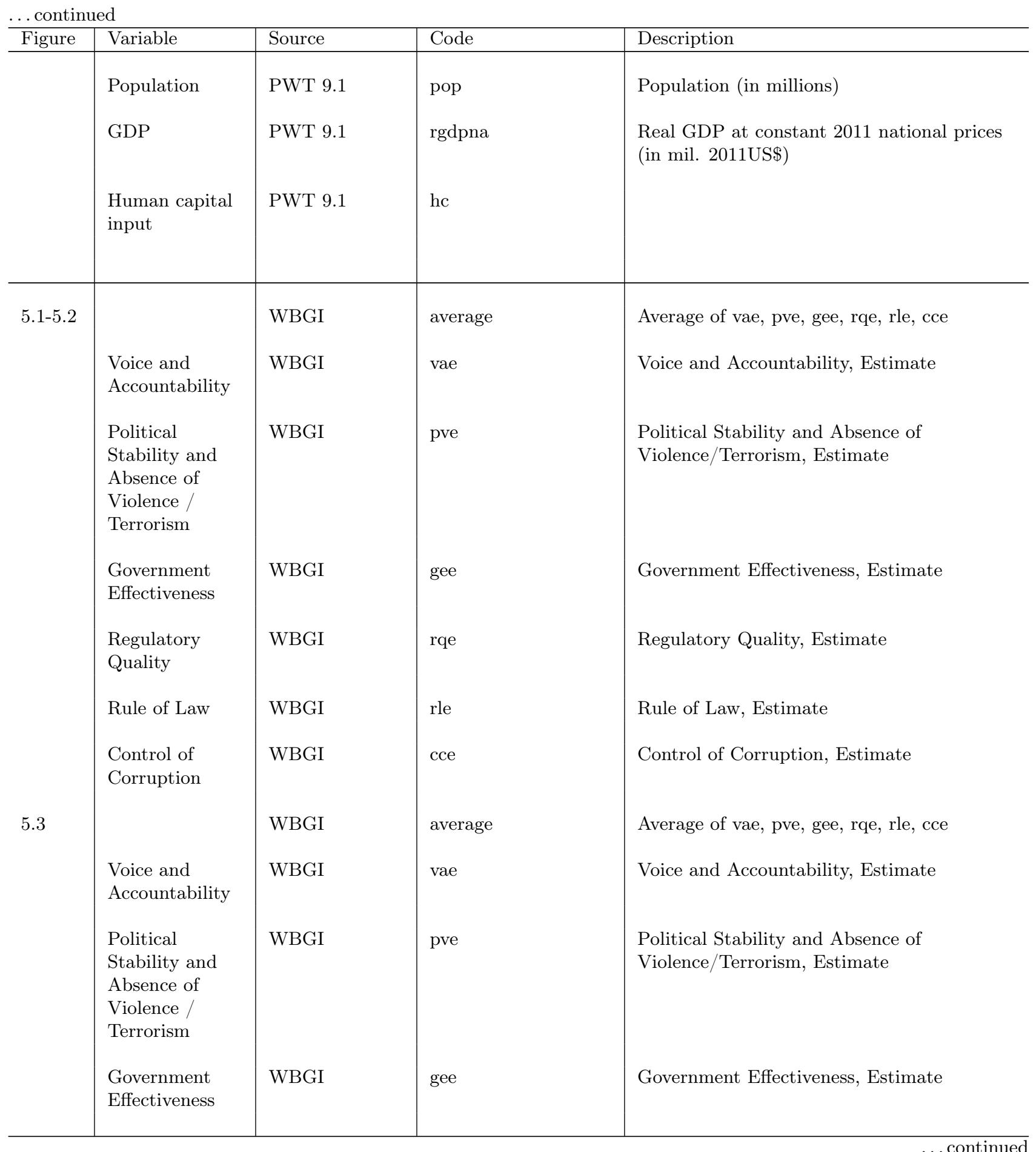




\begin{tabular}{|c|c|c|c|c|}
\hline Figure & Variable & Source & Code & Description \\
\hline \multirow{15}{*}{$5.4-5.5$} & $\begin{array}{l}\text { Regulatory } \\
\text { Quality }\end{array}$ & WBGI & rqe & Regulatory Quality, Estimate \\
\hline & Rule of Law & WBGI & rle & Rule of Law, Estimate \\
\hline & Control of & WBGI & cce & Control of Corruption, Estimate \\
\hline & - & & & \\
\hline & TFP & PWT 9.1 & ctfp & TFP level at current PPPs $(\mathrm{USA}=1)$ \\
\hline & Overall & GCI & GCI4_SCORE & Overall \\
\hline & Institutions & GCI & GCI4.A.01_SCORE & 1: Institutions \\
\hline & Infrastructure & GCI & GCI4.A.02_SCORE & 2: Infrastructure \\
\hline & ICT adoption & GCI & GCI4.A.03_SCORE & 3: ICT adoption \\
\hline & Macro stability & GCI & GCI4.A.04_SCORE & 4. Macro stability \\
\hline & Health & GCI & GCI4.B.05_SCORE & 5: Health \\
\hline & Skills & GCI & GCI4.B.06_SCORE & 6: Skills \\
\hline & Product market & GCI & GCI4.C.07_SCORE & 7: Product market \\
\hline & Labour market & GCI & GCI4.C.08_SCORE & 8: Labour market \\
\hline & Financial & GCI & GCI4.C.09_SCORE & 9: Financial system \\
\hline \multirow{8}{*}{5.6} & Market size & GCI & GCI4.C.10_SCORE & 10: Market size \\
\hline & $\begin{array}{l}\text { Business } \\
\text { dynamism }\end{array}$ & GCI & GCI4.D.11_SCORE & 11: Business dynamism \\
\hline & $\begin{array}{l}\text { Innovation } \\
\text { Capacity }\end{array}$ & GCI & GCI4.D.12_SCORE & 12: Innovation \\
\hline & Overall & GCI & GCI4_SCORE & Overall \\
\hline & Institutions & GCI & GCI4.A.01_SCORE & 1: Institutions \\
\hline & Infrastructure & GCI & GCI4.A.02_SCORE & 2: Infrastructure \\
\hline & ICT adoption & GCI & GCI4.A.03_SCORE & 3: ICT adoption \\
\hline & Macro stability & GCI & GCI4.A.04 SCORE & 4. Macro stability \\
\hline
\end{tabular}




\begin{tabular}{|c|c|c|c|c|}
\hline Figure & Variable & Source & Code & Description \\
\hline & Health & GCI & GCI4.B.05_SCORE & 5: Health \\
\hline & Skills & GCI & GCI4.B.06_SCORE & 6: Skills \\
\hline & Product market & GCI & GCI4.C.07_SCORE & 7: Product market \\
\hline & Labour market & GCI & GCI4.C.08_SCORE & 8: Labour market \\
\hline & $\begin{array}{l}\text { Financial } \\
\text { system }\end{array}$ & GCI & GCI4.C.09_SCORE & 9: Financial system \\
\hline & Market size & GCI & GCI4.C.10_SCORE & 10: Market size \\
\hline & $\begin{array}{l}\text { Business } \\
\text { dynamism }\end{array}$ & GCI & GCI4.D.11_SCORE & 11: Business dynamism \\
\hline & Innovation & GCI & GCI4.D.12_SCORE & 12: Innovation \\
\hline \multirow[t]{2}{*}{$5.7-5.8$} & $\begin{array}{l}\text { Human capital } \\
\text { input }\end{array}$ & PWT 9.1 & hc & \\
\hline & $\begin{array}{l}\text { Human capital } \\
\text { output }\end{array}$ & $\begin{array}{l}\text { Worldbank } \\
\text { Human Capital } \\
\text { Index }\end{array}$ & hci & \\
\hline \multirow[t]{4}{*}{5.9} & TFP & PWT 9.1 & $\operatorname{ctfp}$ & TFP level at current PPPs $(\mathrm{USA}=1)$ \\
\hline & GDP & PWT 9.1 & rgdpna & $\begin{array}{l}\text { Real GDP at constant } 2011 \text { national prices } \\
\text { (in mil. } 2011 \text { US } \$ \text { ) }\end{array}$ \\
\hline & Population & PWT 9.1 & pop & Population (in millions) \\
\hline & $\begin{array}{l}\text { Human capital } \\
\text { input }\end{array}$ & PWT 9.1 & hc & \\
\hline \multirow[t]{3}{*}{5.10} & $\mathrm{TFP}$ & PWT 9.1 & $\operatorname{ctfp}$ & TFP level at current PPPs $(\mathrm{USA}=1)$ \\
\hline & Human capital & $\begin{array}{l}\text { Worldbank } \\
\text { Human Capital } \\
\text { Index }\end{array}$ & & \\
\hline & Governance & WBGI & average & Average of vae, pve, gee, rqe, rle, cce \\
\hline 5.11 & TFP & PWT 9.1 & $\operatorname{ctfp}$ & TFP level at current PPPs $(\mathrm{USA}=1)$ \\
\hline
\end{tabular}




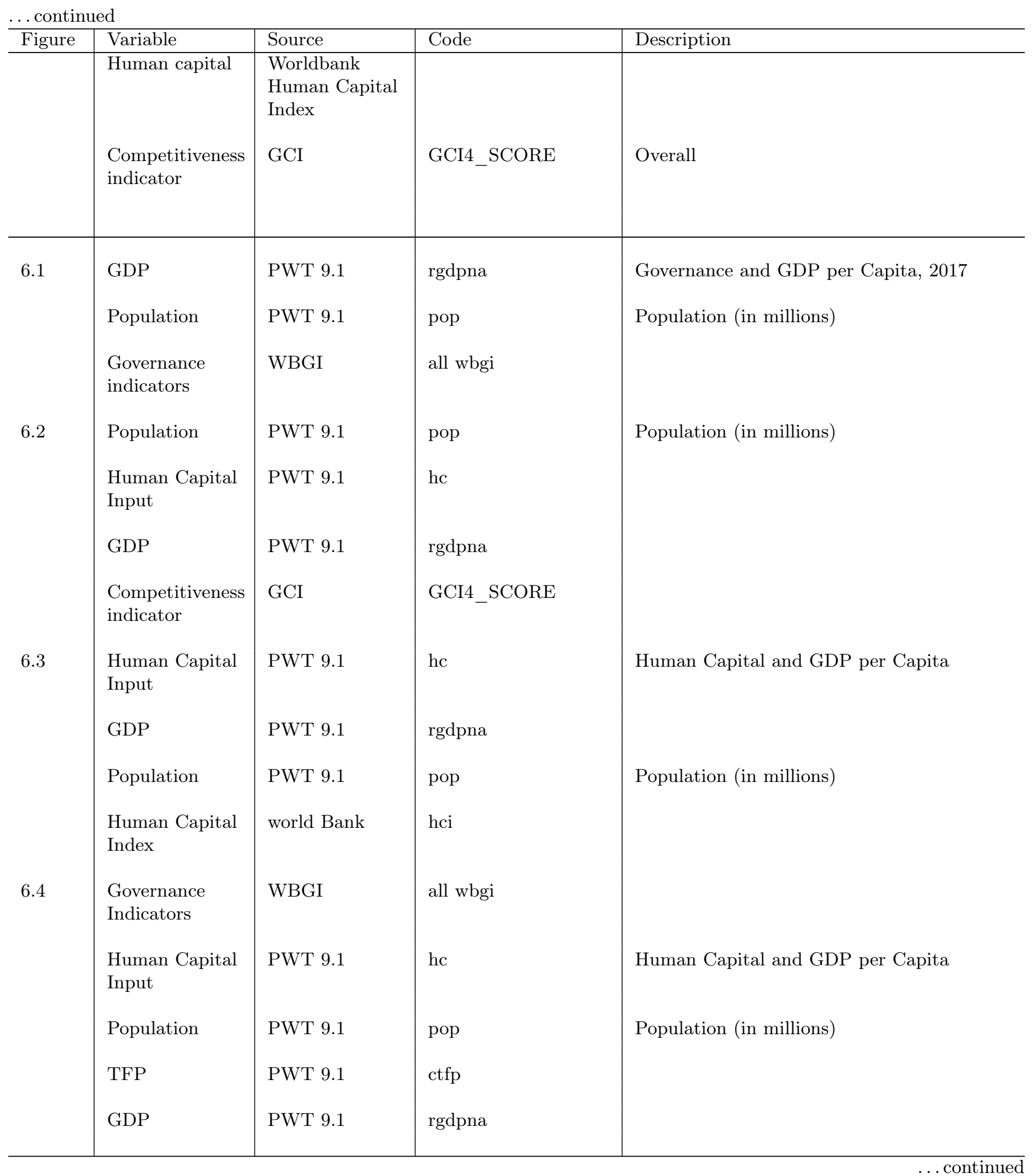




\begin{tabular}{|c|c|c|c|c|}
\hline Figure & Variable & Source & Code & Description \\
\hline 6.5 & $\begin{array}{l}\text { Population } \\
\text { Human Capital } \\
\text { Input } \\
\text { TFP } \\
\text { GDP } \\
\text { Competitiveness } \\
\text { indicator }\end{array}$ & $\begin{array}{l}\text { PWT 9.1 } \\
\text { PWT } 9.1 \\
\text { PWT } 9.1 \\
\text { PWT } 9.1 \\
\text { GCI }\end{array}$ & $\begin{array}{l}\text { pop } \\
\text { hc } \\
\text { ctfp } \\
\text { rgdpna } \\
\text { GCI4_SCORE }\end{array}$ & Population (in millions) \\
\hline 8.1 & Governance & WBGI & average & Average of vae, pve, gee, rqe, rle, cce \\
\hline 8.2 & $\begin{array}{l}\text { Human capital } \\
\text { input }\end{array}$ & PWT 9.1 & hc & Human capital index \\
\hline 8.3 & GDP & PWT 9.1 & rgpdna & $\begin{array}{l}\text { Real GDP at constant } 2011 \text { national prices } \\
\text { (in mil. } 2011 \text { US } \$ \text { ) }\end{array}$ \\
\hline & Population & PWT 9.1 & pop & Population (in millions) \\
\hline & Human capital & PWT 9.1 & hc & Human capital index \\
\hline 8.4 & GDP & PWT 9.1 & rgpdna & $\begin{array}{l}\text { Real GDP at constant } 2011 \text { national prices } \\
\text { (in mil. } 2011 \text { US } \$ \text { ) }\end{array}$ \\
\hline & $\begin{array}{l}\text { Population } \\
\text { EBRD }\end{array}$ & $\begin{array}{l}\text { PWT } 9.1 \\
\text { EBRD TI }\end{array}$ & pop & $\begin{array}{l}\text { Population (in millions) } \\
\text { EBRD Transition Indicators (Index) }\end{array}$ \\
\hline 8.5 & EBRD & EBRD TI & & EBRD Transition Indicators (Index) \\
\hline $8.6,8.9$ & GDP & PWT 9.1 & rgpdna & $\begin{array}{l}\text { Real GDP at constant } 2011 \text { national prices } \\
\text { (in mil. } 2011 \text { US } \$ \text { ) }\end{array}$ \\
\hline & Population & PWT 9.1 & pop & Population (in millions) \\
\hline & Human capital & PWT 9.1 & hc & Human capital index \\
\hline & Governance & WBGI & average & Average of vae, pve, gee, rqe, rle, cce \\
\hline $8.7-8.8$ & GDP & PWT 9.1 & rgpdna & $\begin{array}{l}\text { Real GDP at constant } 2011 \text { national prices } \\
\text { (in mil. } 2011 \text { US } \$ \text { ) }\end{array}$ \\
\hline & Population & PWT 9.1 & pop & Population (in millions) \\
\hline
\end{tabular}




\begin{tabular}{l|l|l|l|l}
... continued \\
\hline Figure & Variable & Source & Code & Description \\
\hline & Human capital & PWT 9.1 & hc & Human capital index \\
\hline
\end{tabular}

